\title{
REGULATION OF GLUCOSE-6-PHOSPHATE DEHYDROGENASE AND HEXOKINASE IN ANOXIA- TOLERANT MARINE MOLLUSCS: ROLE OF REVERSIBLE PROTEIN PHOSPHORYLATION
}

\author{
By \\ Judeh Lama \\ B.Sc. (Hons.), 2006
}

A Thesis Submitted to the Faculty of Graduate Studies and Research in partial fulfillment of the requirements for the degree of

Master of Science

Department of Biology

Carleton University

Ottawa, Ontario, Canada

(C) copyright 2008 


$\begin{array}{ll}\begin{array}{l}\text { Library and } \\ \text { Archives Canada }\end{array} & \begin{array}{l}\text { Bibliothèque et } \\ \text { Archives Canada }\end{array} \\ \begin{array}{l}\text { Published Heritage } \\ \text { Branch }\end{array} & \begin{array}{l}\text { Direction du } \\ \text { Patrimoine de l'édition }\end{array} \\ \begin{array}{l}\text { 395 Wellington Street } \\ \text { Ottawa ON K1A 0N4 } \\ \text { Canada }\end{array} & \begin{array}{l}\text { 395, rue Wellington } \\ \text { Ottawa ON K1A 0N4 } \\ \text { Canada }\end{array}\end{array}$

Your file Votre référence ISBN: 978-0-494-44128-2

Ourfile Notre référence

ISBN: 978-0-494-44128-2

NOTICE:

The author has granted a nonexclusive license allowing Library and Archives Canada to reproduce, publish, archive, preserve, conserve, communicate to the public by telecommunication or on the Internet, loan, distribute and sell theses worldwide, for commercial or noncommercial purposes, in microform, paper, electronic and/or any other formats.

The author retains copyright ownership and moral rights in this thesis. Neither the thesis nor substantial extracts from it may be printed or otherwise reproduced without the author's permission.
AVIS:

L'auteur a accordé une licence non exclusive permettant à la Bibliothèque et Archives Canada de reproduire, publier, archiver, sauvegarder, conserver, transmettre au public par télécommunication ou par l'Internet, prêter, distribuer et vendre des thèses partout dans le monde, à des fins commerciales ou autres, sur support microforme, papier, électronique et/ou autres formats.

L'auteur conserve la propriété du droit d'auteur et des droits moraux qui protège cette thèse. $\mathrm{Ni}$ la thèse ni des extraits substantiels de celle-ci ne doivent être imprimés ou autrement reproduits sans son autorisation.
In compliance with the Canadian Privacy Act some supporting forms may have been removed from this thesis.

While these forms may be included in the document page count, their removal does not represent any loss of content from the thesis.
Conformément à la loi canadienne sur la protection de la vie privée, quelques formulaires secondaires ont été enlevés de cette thèse.

Bien que ces formulaires aient inclus dans la pagination, il n'y aura aucun contenu manquant.

\section{Canada}




\begin{abstract}
Metabolic rate depression is key to animal survival without oxygen and requires coordinated suppression of ATP-generating and ATP-consuming cellular functions by stable regulatory mechanisms. This thesis examined the possible role of reversible protein phosphorylation in metabolic suppression in organs of the anoxia-tolerant intertidal marine mollusc, Littorina littorea. Studies focused on glucose-6-phosphate dehydrogenase (G6PDH), the rate-limiting enzyme of the pentose phosphate pathway (PPP), and hexokinase (HK), an important enzyme at the forefront of carbohydrate metabolism. The data show that hepatopancreas G6PDH is regulated by phosphorylation and entry into anoxia leads to a more dephosphorylated form, whose properties suggest a more active enzyme. This would favour enhanced carbon flow through the PPP to sustain NADPH production for antioxidant defense. Furthermore, the study provides one of the first demonstrations of coordinated regulation of the PPP between active and hypometabolic states and implicates specific protein kinases and phosphatases in G6PDH regulation. Studies of HK showed that it is also regulated by reversible protein phosphorylation, in a tissue-specific manner. In the hepatopancreas, it appears that HK affinity for one of its substrates is enhanced during anoxia whereas in foot muscle, HK activity is suppressed. Differences between control and anoxic HK were also observed in their susceptibility to urea denaturation, response to specific protein kinase and protein phosphatase incubations as well as their elution profiles from an ion-exchange column. Overall, these studies confirm an integral role of reversible protein phosphorylation in the suppression and reorganization of $L$. littorea metabolism for anoxia survival.
\end{abstract}




\section{ACKNOWLEDGEMENTS}

For anyone reading this thesis, this section is a lot harder to write than it seems. You have so much to say but aren't sure how to say it, and in what order to say it in. So here's my best shot. And yes, I know. It's two pages. But what can you do?

First and foremost, I must thank Our Lord and Saviour, Jesus Christ for all the blessings and graces He has bestowed upon me and everyone who has helped towards the completion of this thesis. In Him, I find strength. In Him, I find perseverance. In Him, I find hope. In Him, I find joy. In Him, I find love. In Him, I find peace. Thank you Lord!

To Ken Storey: Thank you so much for being the best supervisor (or Super Advisor) a student can have! It's hard to believe I've been in your lab for 4 years! From the good old LDH days with Kate and Will, driving to the ByWard Market in search for periwinkles, to the Indian Buffet lab lunches and the famous Storey Lab Summer and Christmas parties...just a few of the memories I will cherish and keep with me wherever life takes me. Thanks so much Ken for all your help! You're a really smart guy! And you're a really funny guy too! And its crazy to think it, but sometimes it seemed that you knew me, or at least what I was capable of doing, better than even I knew!

And as the saying goes: behind every great man, there is a great woman. In case you readers didn't know, Jan Storey deserves much of the credit for turning the rambling, drivel of many generations worth of grad students into sophisticated, technical writing which has been published in over 500 journal articles... and counting! And in addition to her fantastic editing skills, she can make some great cookies and banana bread! Yummy!

Thank you to the entire Storey Lab: From back in the day with Dave, Khalil, Jiayun, Mamady and the original nucleus of the lab, Chris Ram. and Pier. To the friends 
in the lab when I started grad school: Chris D., Jacques, Ben, Amal, Anastasia, Marcus. To the new friends I made in my last year in the lab: Oscar, Craig, Neal, Rabih, Obi, Mike, Alex, Anthony, Kristen and Camille. Thanks to all of you for your help with science and everything else. We've had lots of great times: The Jell-O and packing peanut pranks, the sandwich lunches, the youtube videos, Superball, the Clocktower dinners, the Nacho Libre voices, the G.O.A.T, AK-47s, Seinfeld jokes, Arrested Development at lunch, Michael Jordan videos, 24, and Pho! Science definitely shouldn't be this fun!

And I have a feeling I'm forgetting someone! There is this guy who has been in my class ever since elementary school. What's his darn name again.......Ryan! (aka Bell Dawg)! I tried to think of something to say and all I could come up with was that everyday I went to school, I got to be with, talk to, and joke around with my best friend! Not many people can say they got to do that all the way through elementary school, high school, university and grad school! We're definitely like those Muppet Show scientists on the door of the buffer room! There have been so many good times I can't even start writing them down...it'll make this thesis look small and you know we're both trying to make this thing look a decent length, right?

And now to my family! What would I do without you guys? Dad, Mom, Dina and Paul too! It may have been a wild ride, but we all made it through alright. Thank you so much for all your love, for all your support and for all your guidance. More than anyone else, it has been you guys who have been there for me, influenced me and helped me become the person I am. I don't know how I can possibly thank you guys enough! I love you guys so much! 


\section{TABLE OF CONTENTS}

Title Page

Acceptance Sheet

ii

Abstract

iii

Acknowledgements

iv

Table of Contents

vi

List of Abbreviations

vii

List of Tables

$\mathrm{x}$

List of Figures

xi

Chapter 1: General Introduction

Chapter 2: Glucose-6-phosphate dehydrogenase regulation in the

19 hepatopancreas of the anoxia-tolerant marine mollusc, L. littorea

Chapter 3: Hexokinase regulation in the hepatopancreas and foot muscle of the anoxia-tolerant marine mollusc, $L$. littorea

Chapter 4: General Discussion 


\section{LIST OF ABBREVIATIONS}

AMP, ADP, ATP - adenosine mono-, di-, or triphosphate

AMPK - AMP activated protein kinase

$\boldsymbol{\beta}$-GP - $\beta$-glycerol phosphate

Bis-Tris propane - 1,3-bis(tris(hydroxymethyl)methylamino)propane

CaM - calmodulin

CaMK - calmodulin- and $\mathrm{Ca}^{2+}$ - dependent protein kinase

cAMP - 3', 5'-cyclic adenosine monophosphate

CAPS - N-cyclohexyl-3-aminopropanesulfonic acid

cGMP - 3', 5'-cyclic guanosine monophosphate

CHES - N-Cyclohexyl-2-aminoethanesulfonic acid

CREB - cAMP response element binding protein

DEAE - diethylaminoethyl

$\mathbf{E}_{\mathbf{a}}$ - Activation energy

EDTA - ethylenediamine tetraacetate

EGTA - ethyleneglycol bis tetraacetate

$\mathbf{F 2 , 6 P _ { 2 }}$ - fructose-2,6-bisphosphate

G6P - glucose-6-phosphate

G6PDH - glucose-6-phosphate dehydrogenase

GP - glycogen phosphorylase

GPT - glutamate-pyruvate transaminase

GOT - glutamate-oxaloacetate transaminase

HK - hexokinase 
$\mathbf{I}_{\mathbf{5 0}}$ - inhibitor concentration reducing enzyme velocity by $50 \%$

IPA - Insoluble Protein A

kDa - kiloDalton

$\mathbf{K}_{\mathbf{m}}$ - substrate concentration producing half maximal enzyme activity

MAPK - mitogen-activated protein kinase

MDH - malate dehydrogenase

MES - 2-(N-morpholino)ethanesulfonic acid

NADP ${ }^{+}$, NADPH - oxidized and reduced nicotinamide adenine dinucleotide phosphate

NaF - sodium fluoride

$\mathrm{Na}_{3} \mathrm{VO}_{4}$ - sodium orthovanadate

OXA - oxaloacetate

PEG - polyethylene glycol

PEP - phosphoenolpyruvate

PEPCK - phosphoenolpyruvate carboxykinase

PFK-1 - phosphofructokinase-1

PFK-2 - phosphofructokinase-2

PKA - cAMP-dependent protein kinase

PKB - protein kinase B

PKC - $\mathrm{Ca}^{2+}$ - and phospholipid-dependent protein kinase

PK - pyruvate kinase

PKG - protein kinase G

PMA - phorbol myristate acetate

PMSF - phenylmethylsulfonyl fluoride 
PP1 - protein phosphatase type-1

PP2A, PP2B, PP2C - protein phosphatase type-2A, -2B and -2C

ROS - reactive oxygen species

Tris - Tris[hydroxymethyl]aminomethane

$\mathbf{V}_{\max }$ - maximal enzyme velocity 


\section{LIST OF TABLES}

TABLE

PAGE

2.1 Kinetic parameters for G6PDH at $\mathrm{pH} 8.0$ from hepatopancreas of control and $24 \mathrm{~h}$ anoxic $L$. littorea

2.2 Kinetic parameters for G6PDH at $\mathrm{pH} 6.0$ from hepatopancreas of control and $24 \mathrm{~h}$ anoxic L. littorea

2.3 Summary of the incubation studies to investigate the regulation of hepatopancreas G6PDH under control and anoxic conditions of the $L$. littorea

3.1 Kinetic parameters for hexokinase from hepatopancreas of control and $24 \mathrm{~h}$ anoxic $L$. littorea

3.2 The kinetic parameters of foot muscle hexokinase from control and $24 \mathrm{~h}$ anoxic $L$. littorea

3.3 Summary of the incubation studies to investigate the regulation of hexokinase under control and anoxic conditions of the L. littorea 


\section{LIST OF FIGURES}

FIGURE

PAGE

1.1 Anaerobic metabolism in marine molluscs early in anoxia

1.2 Anaerobic metabolism in marine molluscs late in anoxia

15

1.3 General figure depicting the cellular response to an external stress

1.4 General figures representing the important biochemical roles of G6PDH and HK

2.1 Determination of the optimal assay $\mathrm{pH}$ for G6PDH activity from hepatopancreas of control and $24 \mathrm{~h}$ anoxic $L$. littorea

2.2 Effects of in vitro incubations to stimulate the activities of (A) protein kinases or (B) protein phosphatases on the $\mathrm{K}_{\mathrm{m}} \mathrm{G6P}$ of hepatopancreas G6PDH from aerobic control and $24 \mathrm{~h}$ anoxic $L$. littorea

2.3 Results of the radioactive immunoprecipitation of G6PDH from hepatopancreas of $L$. littorea

2.4 DEAE-Sephadex elution profiles for G6PDH activity from hepatopancreas of control and $24 \mathrm{~h}$ anoxic L. littorea

2.5 Representative figure showing possible native phosphorylation states of G6PDH in the hepatopancreas of $L$. littorea, based on the results from the in vitro protein kinase and phosphatase incubations

3.1 Determination of optimal $\mathrm{pH}$ for hexokinase activity from hepatopancreas of control and anoxic L. littorea

3.2 Effects of in vitro incubations to stimulate the activities of (A) protein kinases or (B) protein phosphatases on the $\mathrm{K}_{\mathrm{m}}$ glucose of hepatopancreas HK from aerobic control and $24 \mathrm{~h}$ anoxic $L$. littorea

3.3 Effects of in vitro incubations to stimulate the activities of (A) protein kinases or (B) protein phosphatases on the $\mathrm{K}_{\mathrm{m}}$ ATP of foot muscle $\mathrm{HK}$ from aerobic control and $24 \mathrm{~h}$ anoxic $L$. littorea 
3.4 Results of the radioactive immunoprecipitation of $\mathrm{HK}$ from (A) control hepatopancreas and (B) control foot muscle of $L$. littorea

3.5 DEAE-Sephadex elution profiles for $\mathrm{HK}$ activity from hepatopancreas of control and $24 \mathrm{~h}$ anoxic $L$. littorea

3.6 DEAE-Sephadex elution profiles for HK activity from foot muscle of control and $24 \mathrm{~h}$ anoxic $L$. littorea

3.7 Representative figure showing possible native phosphorylation states of HK in the (A) hepatopancreas and (B) foot muscle of $L$. littorea, based on the results from the in vitro protein kinase and phosphatase incubations 


\section{CHAPTER 1}

\section{General Introduction}


Animals that dwell in the intertidal zone possess a high degree of metabolic plasticity that enables them to tolerate the constantly changing environmental conditions imposed by the tidal cycle. Anoxia tolerance has been well researched in various species of marine molluscs, including both bivalves (e.g. mussels, clams, oysters) and gastropods (e.g. snails, whelks). One such species is the common periwinkle snail, Littorina littorea, which is anoxia tolerant and also survives freezing (English and Storey, 2003).

L. littorea are intertidal gastropod molluscs with a soft body which can be divided into two main parts. The first part is the head and foot region which controls neural activity and locomotion respectively (Curtis and Barnes, 1989). The second part is essentially a visceral mass which is involved in respiration, digestion, reproduction and excretion (Curtis and Barnes, 1989). The hepatopancreas, occupying much of the visceral mass, controls many important functions such as protein synthesis, gluconeogenesis, and glycogenolysis. There are a number of places throughout the skin where respiratory exchange can occur, however the main site is at the surface of the ctenidium (or gills) (Fretter and Graham, 1976).

L. littorea has the capacity to survive long term anoxic and frozen conditions. There are a number of circumstances in which these marine snails can encounter anoxic environments. Since they are an intertidal species, they become oxygen deprived when the waters retreat about every $12 \mathrm{~h}$ at low tide (Truchot and Duhamel-Jouve, 1980). During air exposure periwinkles may arrive at a situation where tissue oxygen is fully exhausted and cellular demands can solely be achieved by anaerobic metabolism. Furthermore, predation as well as high salt or toxin levels in the water can induce closure of the shell (by sealing the entry with the operculum) and lead to progressive hypoxia and 
anoxia (de Zwaan and Putzer, 1985). Also, periwinkles are a freeze-tolerant intertidal species and when their body fluids freeze, tissues are cut off from circulating oxygen and they must endure anoxia and ischemia (Loomis, 1995).

In general, life in the intertidal zone is quite difficult. In addition to the availability of oxygenated water only at high tides, organisms must cope with possible desiccation, changes in salinity, and drastic changes in temperature; all of which can vary rapidly throughout a single tidal cycle (Bridges, 1994). Therefore, in order to cope with the difficult life of the marine intertidal zone, $L$. littorea possess many biochemical adaptations, some of which will now be presented.

\section{Regulation of carbohydrate metabolism}

Under normoxia, organisms use carbohydrates, lipids and amino acids as fuels for respiration; however under anoxia, carbohydrates become the primary fuel source because the catabolism of hexose phosphates (derived from glucose or glycogen) to triose phosphates via glycolysis produces ATP at substrate-level phosphorylation events in the absence of oxygen (Storey and Storey, 2004b).

Although the typical glycolytic pathway produces only $2 \mathrm{~mol}$ ATP/glucose molecule metabolized, which is quite low compared to the $36 \mathrm{~mol}$ ATP/glucose available from aerobic respiration, anoxia tolerant species have adapted these pathways to maximize the length of time that fermentative metabolism can sustain life. Some of these adaptive strategies include: (i) storing large amounts of fermentable fuel (predominantly glycogen with some select amino acids), (ii) coupling glycolysis to additional substratelevel phosphorylation reactions to increase the ATP yield per glucose, (iii) producing 
alternative end-products instead of lactic acid, which are more volatile and less acidic so there are fewer problems with end-product accumulation, and (iv) strongly depressing metabolic rate to lower ATP utilization by tissues to a rate that can be sustained over a long period of time by the ATP output of fermentative reactions alone (Storey and Storey, 1990; Churchill and Storey, 1996; Storey and Storey, 2004b; Larade and Storey, 2007). Thus, the Pasteur effect, which is characterized by a large increase in glycolytic rate when oxygen is limiting, is not seen in anoxia-tolerant species primarily due to the profound decrease in metabolic rate (Larade and Storey, 2002).

Interestingly, most anoxia-tolerant species, including $L$. littorea, display a biphasic response to declining oxygen tension. Initially as organisms encounter hypoxia, fermentative ATP output increases in order to compensate for declining ATP output from respiration and maintain normal rates of ATP turnover. However, as hypoxia deepens towards anoxia, a critical low oxygen tension is exceeded and further attempts at compensation are abandoned in favour of the initiation of conservation strategies (Shick et al., 1983; Larade and Storey, 2002). The rates of ATP production and utilization are then strongly depressed and net metabolic rates drop to $<10 \%$ of normoxic rates in most intertidal molluscs (de Zwann et al., 1991; van den Thillart et al., 1992; Storey, 1993). Marine molluscs, land snails, some fish, and turtles withstand long periods of anoxia by lowering their metabolic rate (Brooks and Storey, 1997). By arresting metabolism at an early stage in response to external stresses, animals can limit or prevent metabolic and cellular damage (Brooks and Storey, 1997). Furthermore, metabolic rate depression greatly increases the time that fixed reserves of internal fuels can support survival and 
thus, many marine molluscs are able to survive days or weeks of anoxia (Larade and Storey, 2002).

In addition to metabolic rate depression, which is the most important factor in anoxia survival, facultative anaerobes modify the pathways of fermentative metabolism to increase ATP output and form less acidic, more volatile end-products that are compatible with the maintenance of long term homeostasis in the anoxic state. Initially, marine molluscs couple glycogen fermentation with aspartate fermentation in order to produce the end-products alanine and succinate, respectively (Figure 1.1). As glycogen is catabolized to pyruvate via glycolysis, instead of its normal reduction to lactate, pyruvate undergoes a transamination reaction to form alanine using an amino group transferred from aspartate, which becomes oxaloacetate (Figure 1.1; Storey and Storey, 2004b). Oxaloacetate is reduced to malate, which enters the mitochondria and is converted to fumarate, which generates ATP by its further conversion into succinate (Figure 1.1). Therefore, the coupled metabolism of glycogen and aspartate doubles the normal glycolytic output compared to the situation where lactate was the sole end-product; from 2 mol ATP to 4 mol ATP per glucose catabolized (Larade and Storey, 2004).

With longer periods of anoxia, aspartate pools become depleted and carbon from glycolysis directly enters the pathways of succinate synthesis, also yielding 4 mol ATP (Figure 1.2; Storey and Storey, 2004b). In doing so, glycolysis proceeds, as normal, to phosphoenolpyruvate (PEP) but then carbon is diverted to PEP carboxykinase (PEPCK) instead of pyruvate kinase (PK). This diversion is controlled by the anoxia-induced inhibition of PK (Larade and Storey, 2004b). PEPCK converts PEP into oxaloacetate, which then feeds into the reactions of succinate synthesis, thus producing ATP (Figure 
1.2; Larade and Storey, 2002). When anoxia is prolonged, succinate can be further catabolized to produce volatile end-products, acetate and propionate, associated with a further increase in the ATP yield (Figure 1.2; Storey and Storey, 2004b).

\section{Effect of $\mathbf{p H}$}

During anoxia, both intracellular and extracellular $\mathrm{pH}$ decrease in marine molluscs, but it is still uncertain whether changes in $\mathrm{pH}$ have a role in initiating metabolic suppression (Ellington, 1983; Walsh, et al., 1984). The decrease in $\mathrm{pH}$ during anoxia is typically a steady, gradual decline over an extended time period, whereas the transition into the hypometabolic state during anaerobiosis occurs shortly after anoxia begins (Storey and Storey, 1990). Therefore, since $\mathrm{pH}$ changes take place gradually, it is unlikely to play a role in signaling metabolic suppression during anaerobiosis. Furthermore as described earlier, facultative anaerobes such as $L$. littorea use mechanisms to minimize acidosis during anoxia by accumulating neutral or volatile products as well as mobilizing $\mathrm{CaCO}_{3}$ from their shell to enhance buffering capacity; and this argues against the potential role for a decreased $\mathrm{pH}$ being a signal for metabolic rate depression (de Zwaan, 1977; Storey and Storey, 1990). Although a low pH may not be a signal for the commencement of a suppressed metabolic rate, it does provide an environment that facilitates anaerobic metabolism (Busa and Nuccitelli, 1984). An example of this is that a lower $\mathrm{pH}$ environment favours catabolism of PEP via PEPCK rather than PK, and therefore plays a role in diverting glycolytic carbon into succinate synthesis pathways during long-term anoxia (Figure 1.2; Hochachka and Somero, 1984). During anoxia, a decrease in $\mathrm{pH}$ may also assist other actions such as enzyme binding 
with subcellular structural elements, enzyme reaction rates, the relative activities of protein kinases versus phosphatases and changing protein stability (Storey, 1988a; Hand and Hardewig, 1996; Schmidt and Kamp, 1996; Sokolova et al., 2000).

\section{Controlling Glycolytic Flux}

There are a variety of mechanisms which play a role in the anoxia-induced regulation of glycolytic rate in marine molluscs such as allosteric controls and $\mathrm{pH}$. Fructose-2-6-bisphosphate $\left(\mathrm{F}_{2}, 6 \mathrm{P}_{2}\right)$ levels decrease and L-alanine levels increase which result in the anoxia-induced inhibition of phosphofructokinase-1 (PFK-1) and pyruvate kinase (PK) respectively. Both PFK-1 and PK are key, rate-limiting enzymes of glycolysis and their inhibition strongly decreases the rate of glycolysis (Brooks et al., 1991; Lazou, 1991; Michaelidis and Storey, 1990; Michaelidis and Storey, 1991; Storey and Storey, 2004b). Decreases in the cellular concentrations of $\mathrm{F} 2,6 \mathrm{P}_{2}$ are both rapid and profound during environmental anoxia in many molluscs and are evident in almost all tissues of the marine whelk, Busycon canaliculatum (Storey, 1988b). Also as mentioned earlier, the reduced cellular $\mathrm{pH}$ in anoxia regulates glycolytic flux by favouring PEP processing via PEPCK instead of PK (Storey and Storey, 2004b).

\section{Seasonal Effects}

Anoxia exposure has a generally stronger effect on the maximal activities of selected glycolytic enzymes in animals gathered in winter versus summer seasons and these seasonal changes are often closely linked to the reproductive cycle (Greenway and Storey, 2001). The metabolic reorganization that accompanies these seasonal cycles of 
growth and reproduction may necessitate changes in the activities of selected enzymes (Livingstone, 1981; Gabbott, 1983). This was observed in the strong effects of anoxia on the kinetic properties of PK from hepatopancreas of winter $L$. littorea versus the relatively small effects on the summer enzyme (Greenway and Storey, 2001). However, differences in enzyme kinetic parameters over seasonal cycles can also be tissue-specific, as evidenced by foot muscle PK showing similar sensitivity to anoxia in both seasons (Greenway and Storey, 2001). Therefore, it appears that seasonal changes in enzyme properties due to anoxia may aid prolonged periods of cold-induced inactivity and selfimposed hypoxia/anoxia which initiates metabolic rate depression.

\section{Reversible Protein Phosphorylation}

Although the above mentioned mechanisms aid in glycolytic control, the dominant mechanism of controlling glycolysis during anoxia is reversible protein phosphorylation (Storey and Storey, 2004a). These covalent modifications are performed by protein kinases and protein phosphatases. Major kinases implicated in the reversible control of enzymes of intermediary metabolism are PKA, PKG and PKC, whose actions are mediated by their respective second messengers: adenosine 3',5'-cyclic monophosphate (cAMP), guanosine 3',5'-cyclic monophosphate (cGMP), and $\mathrm{Ca}^{2+}$ and phospholipids (Larade and Storey, 2002). The degree of enzyme phosphorylation is, by extension, directly linked to the activity of membrane receptors and internal signals that serve to associate an external signal to changes in second messenger compounds (Figure 1.3a; Brooks and Storey, 1997). Activation of receptors leads to altered cellular 
concentrations of second messenger compounds by stimulating enzymes situated at the plasma membrane (Beavo, 1988; Benovic et al., 1988; Ross, 1980).

Control of enzyme activity is central to anoxia survival (Eberlee and Storey, 1988). Reversible protein phosphorylation can greatly affect the maximal activity and kinetic properties of enzymes, which can therefore suppress overall glycolytic rate. These covalent modifications are quite energy efficient, when compared to other mechanisms of altering enzyme activity including increasing/decreasing transcription and translation to alter the amount of enzyme protein, or protein degradation mechanisms (Storey and Storey, 2004a). This energetically shrewd way of modifying enzymes at the post-translational level further benefits the animal coping with a stress because it requires much less ATP than transcription and translation which utilize large quantities of ATP.

Many glycolytic enzymes in L. littorea undergo anoxia-induced phosphorylation to decrease their activity such as glycogen phosphorylase (GP), PFK-1, 6-phosphofructo2-kinase (PFK-2) and PK (Storey, 1993). Glycogen is present in high quantities in tissues of the marine mollusc and control of GP is necessary to regulate the availability of the primary fuel source in anoxia. As explained earlier, the product of PFK-2, F2,6 $\mathrm{P}_{2}$, is a potent activator of PFK-1, which itself greatly affects the rate of glycolysis. By inhibiting PFK-2 and thereby suppressing levels of $\mathrm{F} 2,6 \mathrm{P}_{2}$, the rate of glycolysis can be regulated. Furthermore, regulation of PK controls the route for the catabolism of PEP, directing glycolysis away from PK, and towards PEPCK which leads to the anaerobic synthesis of succinate or propionate from glucose (de Zwann, 1977).

During anoxia, PK in the marine whelk, B. canaliculatum, is phosphorylated, thus altering the kinetics of PK and making it a much less active enzyme (Brooks and Storey, 
1990). For example, in the anoxia-tolerant whelk, phosphorylation of PK results in a 12fold increase in the $\mathrm{K}_{\mathrm{m}}$ for PEP, a 24-fold increase in the $\mathrm{K}_{\mathrm{a}}$ for fructose-1,6bisphosphate, and a 490-fold decrease in the $\mathrm{K}_{\mathrm{i}}$ for alanine (Plaxton and Storey, 1984a). Anoxia-induced PK phosphorylation initially appeared to be stimulated by cGMP, which would imply a key role for PKG in the transition to anoxia (Brooks and Storey, 1990). However, a more in-depth examination of PKG control of PK found that it was actually an indirect control, with PKG apparently stimulating a specific PK-kinase which, in turn, phosphorylated and inactivated PK (Brooks and Storey, 1991). Also, phosphorylation of PK in the anoxia-tolerant sea mussel Mytilus edulis was sensitive to $\mathrm{Ca}^{2+}$ and cAMP and this suggested a role for PKC and PKA (Holwerda et al., 1983; Holwerda et al., 1989).

Similarly, in the anterior byssus retractor muscle (ABRM) of M. edulis, phosphorylation of PFK-1 by PKG altered kinetic properties to convert the enzyme to a less active form (Michaelidis and Storey, 1990). Also, it appears that an increase in cGMP, the second messenger for PKG, occurs in the ABRM in response to acetylcholine, the neurotransmitter which stimulates the contraction of the ABRM to close its shell (Kohler and Lindl, 1980). The significance of this is that for bivalve molluscs, shell valve closure is the proximal event that leads to internal oxygen depletion which necessitates the initiation of anaerobic adaptations. Furthermore, PKA has been shown to phosphorylate numerous physiological substrates in vivo and can be linked to several processes including ion transport across membranes, control of glycolytic rate, and the heat shock protein response (Zetterqvist et al., 1990; Walsh et al., 1991; Pearson and Kemp, 1991). The potential for wide-ranging effects by PKG, PKC, PKA and other 
protein kinases and phosphatases in the control of other metabolic responses to anoxia in L. littorea is high but remains largely unexplored.

\section{Glucose-6-phosphate branch point}

Having introduced the animal of interest, the stress it must cope with, and the importance of reversible protein phosphorylation, it is now suitable to discuss the enzymes which will be investigated and their importance to the life of the marine snail.

Most cellular processes depend on the metabolism of carbohydrates for energy and biosynthetic precursors. Glucose is a key metabolite for all organisms and at the forefront of carbohydrate metabolism is the enzyme hexokinase (HK; E.C. 2.7.1.1), which the cell depends on to begin many catabolic and anabolic processes. Hexokinase catalyzes the addition of the $\gamma$-phosphoryl group of an energy molecule, typically ATP, to a hexose sugar, normally glucose. In mammals, there are four isozymes (HK I-IV) that differ in subcellular and tissue distribution (Katzen and Schimke, 1965). The hexokinase reaction produces glucose-6-phosphate (G6P), and it is this molecule that acts as the branching point of carbohydrate metabolism within the cell because it can enter a variety of pathways (Figure 1.4a; Wilson, 2003). These include glycolysis to generate ATP, the pentose phosphate pathway (PPP) to produce NADPH and sugar phosphates, and the synthesis of glycogen as a storage fuel for future use (Wilson, 2003). Another benefit of phosphorylating glucose to produce G6P is that it removes free glucose from the intracellular pool, thereby facilitating continued entry of glucose into the cell down its concentration gradient. 
Branching off glycolysis is the pentose phosphate pathway which takes G6P, and creates sugar phosphates and NADPH (Salway, 2004). Glucose-6-phosphate dehydrogenase (G6PDH, E.C. 1.1.1.49) catalyzes the first and rate-limiting step of the PPP: the oxidation of G6P into 6-phosphogluconolactone, along with the reduction of $\mathrm{NADP}^{+}$to NADPH. The sugar phosphates synthesized in this pathway are precursors to the synthesis of nucleic acids and many other cellular biomolecules, whereas the reducing power supplied by NADPH is used for many forms of biosynthesis (Salway, 2004). Furthermore, NADPH provides the reducing power for many detoxification and biotransformation reactions catalyzed by cytochrome $\mathrm{P} 450$ as well as for antioxidant defenses, generating the reduced forms of glutathione and thioredoxin (Figure 1.4b; DiGiulio et al., 1989; Das and White, 2002; Berg et al., 2002). Reduced glutathione can scavenge singlet oxygen molecules and also acts as a substrate for GST-catalyzed antioxidant reactions (Abeles et al., 1992; Garrett and Grisham, 2005).

An abrupt reintroduction of oxygen into a hypoxic or anoxic system leads to the rapid generation of reactive oxygen species (ROS) which include the superoxide anion radical $\left({ }^{\circ} \mathrm{O}_{2}{ }^{-}\right)$, hydrogen peroxide $\left(\mathrm{H}_{2} \mathrm{O}_{2}\right)$, and the hydroxyl radical ( $\left.{ }^{\circ} \mathrm{OH}\right)$; the latter being the most reactive and destructive (Storey and Storey, 2004a). ROS have numerous deleterious effects on biological macromolecules and damage lipids, proteins and DNA (Halliwell and Gutteridge, 1989; Floyd, 1990; Traystman et al., 1991). Being a facultative anaerobe, $L$. littorea experience wide variations in tissue oxygen levels and have developed mechanisms to deal with the potential for damage due to ROS overgeneration during transitions from anoxic to normoxic life. The snails maintain high antioxidant defenses throughout the year, along with the further enhancement of these 
defenses under anoxic conditions in preparation for when oxygen is reintroduced, namely the buildup of NADPH reducing power (DiGiulio et al., 1989; Ramnanan and Storey, 2006a). Also, these marine molluscs have a greater tolerance for the build up of products of oxidative damage as well as improved mechanisms for their clearance.

\section{Objectives}

Reversible protein phosphorylation has been identified as a critical mechanism of metabolic regulation in many animal systems and has been shown to play an important role in mediating and coordinating metabolic rate depression in a variety of animals that undergo anoxia and other environmental stresses. Previous work from our lab has shown that reversible phosphorylation is vital in the regulation of carbohydrate catabolism in many animals from the estivating snail Otala lactea to the hibernating ground squirrel, Spermophius richardsonii (Ramnanan and Storey, 2006a; Ramnanan and Storey, 2006b; Abnous and Storey, 2007; Abnous and Storey, 2008). The research described in this thesis attempts to assess the possible role of reversible phosphorylation in regulating key areas of metabolism in the marine mollusc, L. littorea, specifically glycolysis and the pentose phosphate pathway. Furthermore, although it has been demonstrated that the periwinkle possess both natural anoxia and freeze tolerance, the stressor which will be investigated in this thesis will focus on a complete lack of oxygen in its environment. This external factor will cause a stress on the animal which will result in a variety of internal events such as changes in second messenger levels, activities of protein kinases and protein phosphatases, subsequent protein phosphorylation, the decrease in levels of anoxic fuels such as glycogen and alanine, and the accumulation of anoxic end-products. 
The following objectives were tested in the anoxia-tolerant $L$. littorea model:

1. The activity of G6PDH, the rate-limiting enzyme of the pentose phosphate pathway, is enhanced during anoxia, and the mechanism of regulation is reversible phosphorylation.

2. The activity of HK, the first step in glycolysis, may be regulated by reversible phosphorylation in a tissue-specific manner; and this regulation may be related to the different needs for HK function in the hepatopancreas and foot muscle. 
Figure 1.1. Anaerobic metabolism in marine molluscs early in anoxia. Pyruvate kinase (PK) produces pyruvate which is then converted to alanine by the enzyme glutamatepyruvate transaminase (GPT). This reaction is coupled to the conversion of aspartate to oxaloacetate (OXA) catalyzed by the enzyme, glutamate-oxaloacetate transaminase (GOT). OXA is reduced to malate by malate dehydrogenase (MDH) and in the mitochondria, malate is converted to succinate with the generation of ATP (Figure from Storey and Storey, 2004b). 
Figure 1.1

\section{GLYCOLYSIS}

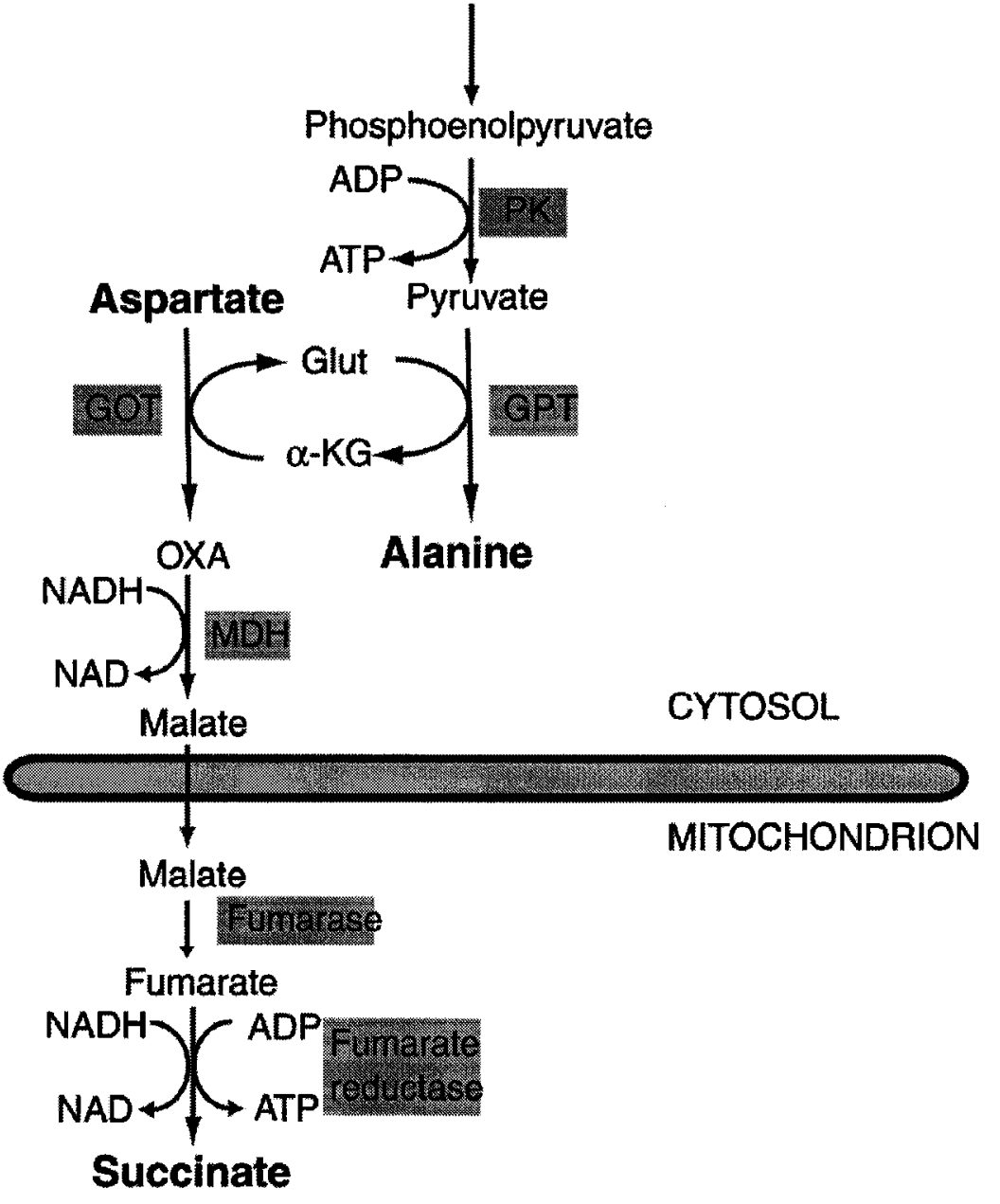


Figure 1.2. Anaerobic metabolism in marine molluscs late in anoxia. As aspartate pools become depleted, glycolytic carbon is shunted directly into reactions of succinate synthesis. Inhibition of PK promotes phosphoenolpyruvate (PEP) conversion to oxaloacetate via PEP carboxykinase (PEPCK). Once again, the conversion of malate to succinate produces ATP and the further production of volatile end-products, acetate and propionate only occur during prolonged anaerobiosis (Figure from Storey and Storey, 2004b). 
Figure 1.2

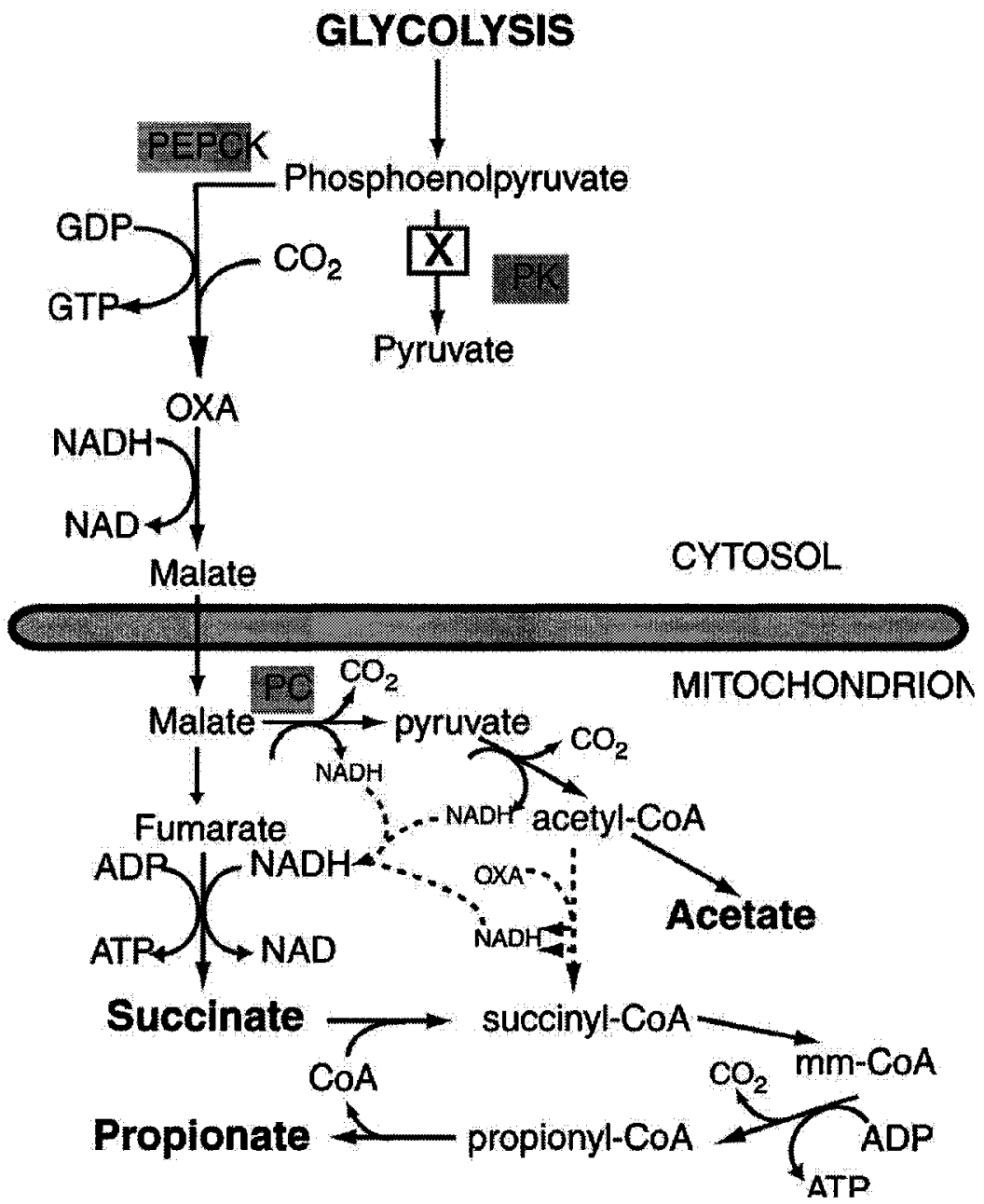


Figure 1.3. General figure depicting the cellular response to an external stress. A stress (low oxygen levels) is detected by sensory cells which emit specific signals. These signals bind to a membrane receptor (G-protein), which becomes activated and then subsequently activates an effector molecule (adenylate cyclase). This effector molecule can activate specific second messengers (cAMP) which go on to activate specific protein kinases (protein kinase A) which can affect many processes in the cell including phosphorylating enzymes to change their kinetic properties and regulate metabolism. 
Figure 1.3

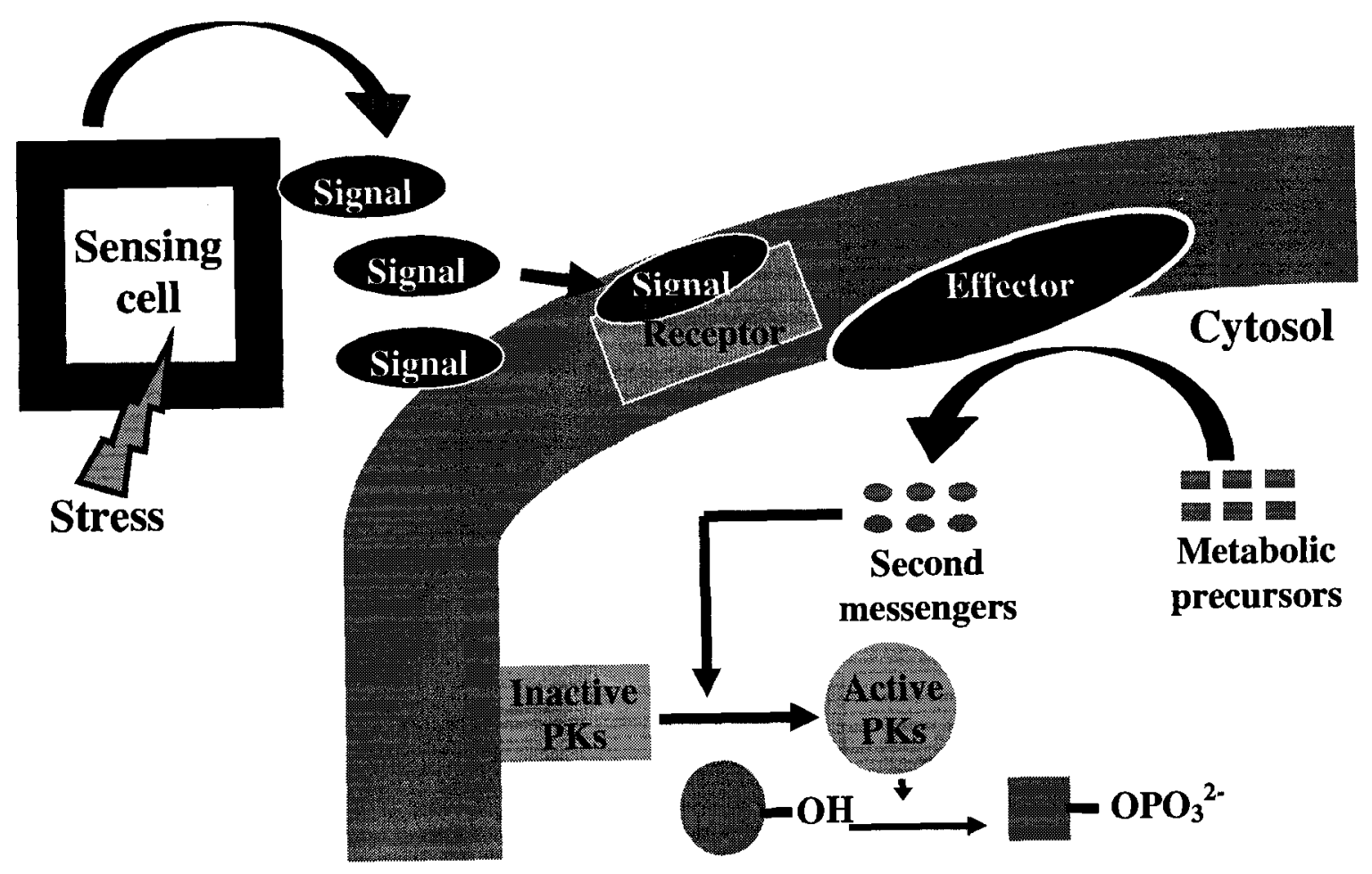


Figure 1.4. General figures representing the important biochemical roles of the two enzymes investigated in this thesis. (A) HK produces glucose-6-phosphate (G6P), a key branch point metabolite. G6P can enter many pathways of glucose utilization such as glycolysis, the pentose phosphate pathway, and glycogen synthesis. Other important functions include the generation of UDP-Glc and Glc-NAc which are used respectively for nucleotide sugar metabolism and as monomer subunits of chitin, a hard polymer that forms the exoskeleton of arthropods and also the radula of molluscs (adapted from Robey and Hay, 2006). (B) G6PDH gates the pentose phosphate pathway and produces NADPH which is used in a wide variety of biosynthetic, redox and antioxidant functions in the cell (adapted from Abeles et al., 1992). 
Figure 1.4

A

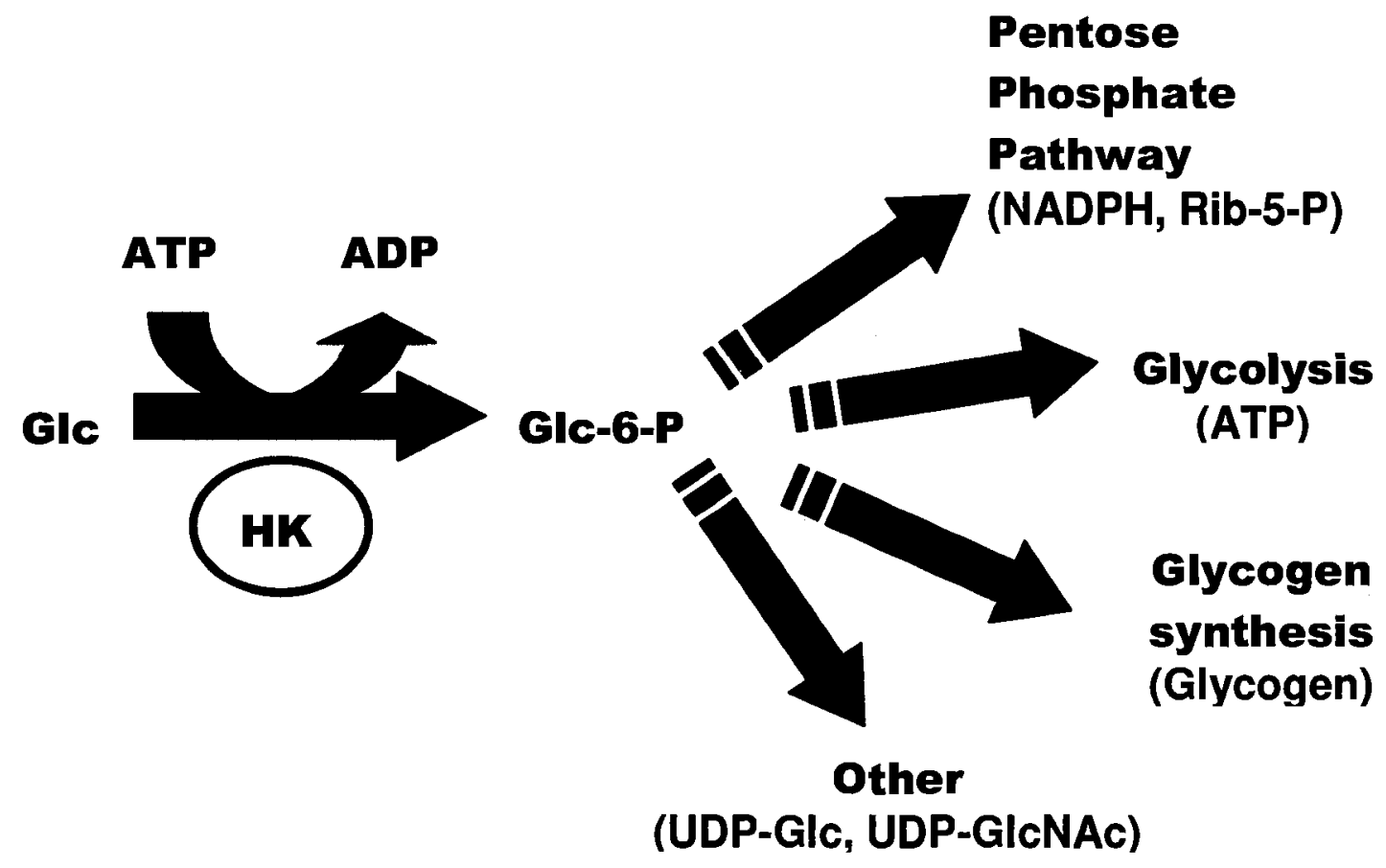

B

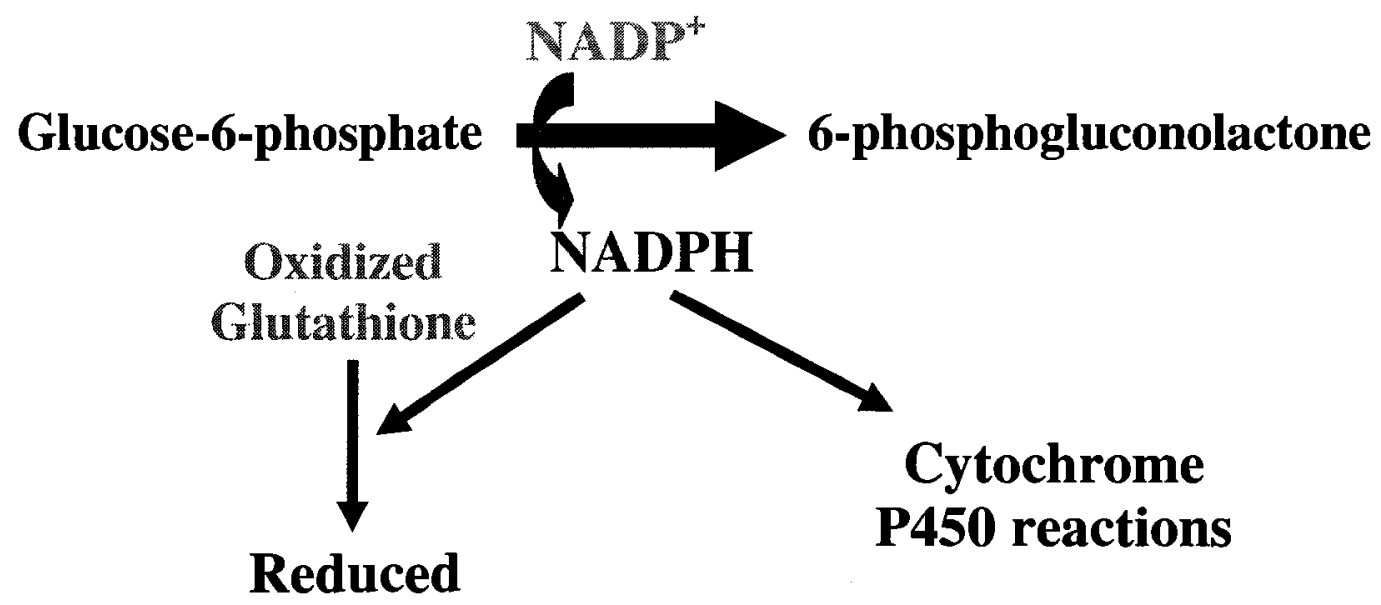

Glutathione 


\section{CHAPTER 2}

\section{Glucose-6-phosphate dehydrogenase regulation in the hepatopancreas of the anoxia-tolerant marine mollusc, $L$. littorea}




\section{Introduction}

Glucose-6-phosphate dehydrogenase (G6PDH) (E.C. 1.1.1.49) catalyzes the first of two oxidative steps in the pentose phosphate pathway (PPP) and is also the ratelimiting step in the pathway:

D-glucose-6-phosphate $+\mathrm{NADP}^{+} \rightarrow$ D-6-phosphoglucono- $\delta$-lactone $+\mathrm{NADPH}+\mathrm{H}^{+}$

In this dehydrogenation reaction, the hemiacetal hydroxyl group on carbon 1 of glucose-6-phosphate (G6P) is converted into a carbonyl group, producing a lactone, which, in the process, generates NADPH. This lactone is immediately hydrolyzed to form 6-phosphogluconate, the substrate of the second NADPH-producing reaction, catalyzed by 6-phosphogluconate dehydrogenase.

The pentose phosphate pathway has several important functions in cells and the one which is of particular relevance to anoxia-tolerant snails is the production of reducing equivalents of NADPH which are used in several forms of antioxidant defense.

Protection against oxidative stress is needed by organisms undergoing hypometabolism for two primary reasons: (a) for long term protection of macromolecules in the hypometabolic state where the rates of biosynthesis of new macromolecules are low, and (b) to cope with a rapid, large increase in oxyradical formation associated with arousal from dormancy when oxygen consumption increases rapidly. Studies have shown that antioxidant defenses, such as pools of reduced glutathione, are elevated in anoxic $L$. littorea to help protect cells from oxidative injuries during aerobic recovery (Pannunzio and Storey, 1998).

It has been established that mammalian G6PDH activity can be regulated by reversible phosphorylation (Costa Rosa et al., 1995; Zhang et al., 2000; Xu et al., 2005), 
although these studies were limited to examining the effect of phosphorylation on maximal velocity (which decreased). Only recently, has it been confirmed that phosphorylation control of G6PDH is implicated as a component of metabolic rate depression in a system of natural hypometabolism (Ramnanan and Storey, 2006a). There are two possible outcomes which might be predicted from a study of the regulation of G6PDH in the hepatopancreas of L. littorea. On the one hand, suppression of G6PDH activity could be expected so that pentose phosphate pathway activity is reduced in concert with the general suppression of carbohydrate catabolism. On the other hand, maintenance or perhaps even enhancement of NADPH supply is vital to sustaining antioxidant defenses during long term dormancy. The present study examines G6PDH regulation in the anoxia-tolerant intertidal marine snail, $L$. littorea. I predicted that G6PDH would be differentially regulated in anoxia, and the mechanism responsible would be a form of posttanslational modification, namely protein phosphorylation.

\section{Materials and Methods}

\section{Animals}

Snails (common periwinkle, Littorina littorea) were purchased from the Kowloon Market, Ottawa in May 2007. They were washed, rinsed, cleaned in tap water and then given a final rinse in seawater. Afterwards snails were placed in a $30 \mathrm{~L}$ tub of aerated, full strength seawater (1000 mOsmol/L made using Instant Ocean Sea Salt; salinity confirmed with a buoyancy meter) at $9^{\circ} \mathrm{C}$ in an incubator with constant darkness. No food was provided but the water was changed periodically and dead snails were removed. 
Experiments to gather aerobic control (sampled directly from the seawater) and $24 \mathrm{~h}$ anoxic snails were commenced after 7 days of acclimation.

For anoxia exposure, 25 snails were placed in each of several sealed jars (clear plastic, with two gas ports in their tops) which were held on ice. These contained a small amount of deoxygenated seawater $(1 \mathrm{~cm}$ deep) which had been bubbled previously with $\mathrm{N}_{2}$ gas for 30 min before being added to the jars. The lids were tightened and sealed with parafilm and then a gas line was connected to one of the ports whereas the other port was opened to vent the gas. $\mathrm{N}_{2}$ gas was continuously bubbled into the water in the jars for a further $20 \mathrm{~min}$. Then the $\mathrm{N}_{2}$ line was removed, the ports were closed and the containers were returned to the $9^{\circ} \mathrm{C}$ incubator for a $24 \mathrm{~h}$ anoxia exposure.

For sampling anoxic snails, a container of snails was removed from the incubator, placed on ice and the nitrogen gas tubing was reattached and gassing started. The lid was loosened and snails were quickly removed from the jar, one per person, and then the lid was retightened to maintain gassing. Snails were dissected immediately. A couple of sharp hammer blows were used to crack and remove the outer shell and then hepatopancreas and foot muscle were excised and frozen in liquid nitrogen. Tissues were stored in labeled plastic jars at $-80^{\circ} \mathrm{C}$.

\section{Sample preparation}

Frozen samples of hepatopancreas were homogenized $1: 5 \mathrm{w}: \mathrm{v}$ in cold, $4^{\circ} \mathrm{C}$ homogenization buffer containing $50 \mathrm{mM}$ Tris- $\mathrm{HCl}, 10 \%$ v:v glycerol, $10 \mathrm{mM} 2-$ mercaptoethanol, $2.5 \mathrm{mM}$ EDTA and 2.5 mM EGTA, pH 7.5. The buffer components were optimized with respect to the effects of sodium fluoride $(\mathrm{NaF})$ and $\beta$-glycerol 
phosphate ( $\beta$-GP) on enzyme activity and, after optimization, $25 \mathrm{mM} \mathrm{NaF}$ was also included in the homogenization buffer. A few crystals of phenylmethylsulfonyl fluoride (PMSF), a protease inhibitor, were added at the time of homogenization. Homogenates were centrifuged at $13,500 \mathrm{~g}$ for $30 \mathrm{~min}$ at $4^{\circ} \mathrm{C}$ and the supernatant was decanted and held on ice.

\section{Sephadex G-50 filtration of crude extracts}

To properly assess G6PDH properties, low molecular weight metabolites and ions needed to be removed from the enzyme preparation. This was achieved by Sephadex G50 gel filtration. A $5 \mathrm{~cm}$ column of Sephadex G-50 in a syringe barrel was equilibrated in homogenization buffer and centrifuged at $500 \mathrm{~g}$ in a bench-top centrifuge for $2 \mathrm{~min}$ to remove excess buffer which was discarded. Then a $500 \mu \mathrm{L}$ aliquot of supernatant was layered on top, the column was centrifuged again, as above; and the protein-containing eluant was removed and stored on ice.

\section{G6PDH assays}

G6PDH activity was assayed at $340 \mathrm{~nm}$ using a Thermo Labsystems Multiskan Spectrum Microplate Spectrophotometer (kinetic mode, reading interval = $21 \mathrm{~s}$ ). Optimal assay conditions were $4 \mathrm{mM}$ G6P, $1.0 \mathrm{mM} \mathrm{NADP}^{+}$in $50 \mathrm{mM}$ Tris- $\mathrm{HCl}$ buffer, $\mathrm{pH}$ 8.0. Reactions were initiated by adding $5 \mu$ l of enzyme extract $(10 \mu l$ for incubation studies or $50 \mu \mathrm{l}$ for assaying column fractions) to a $200 \mu \mathrm{L}$ total reaction volume in the microplate well. Microplate Analysis (MPA) and Kinetics 3.51 computer programs were used to analyze data and determine $V_{\max }$ and $K_{m}$ values. One unit of G6PDH activity is defined 
as the amount of enzyme that produces $1 \mu \mathrm{mol}$ 6-phosphogluconolactone per min at $22^{\circ} \mathrm{C}$ and activities were expressed as $\mathrm{mU} / \mathrm{mg}$ soluble protein. Soluble protein content was quantified using the Coomassie blue dye binding method and the Bio-Rad prepared reagent with a standard curve for bovine serum albumin.

\section{pH studies}

A pH profile of G6PDH activity from the hepatopancreas of L. littorea was conducted by measuring G6PDH activity under optimal conditions at $22^{\circ} \mathrm{C}$ for $\mathrm{pH}$ values ranging from 6.0 to 11.0. A 50 mM Bis-Tris Propane buffer was used for pH 6.0-9.0 and a CAPS buffer was used for $\mathrm{pH}$ 9.5-11.0. Standard kinetic parameters were determined at $\mathrm{pH} 6.0$ and $\mathrm{pH} 8.0$ for hepatopancreas preparations from both control and $24 \mathrm{~h}$ anoxic conditions. For pH 6.0 assays, MES buffer was used for both homogenization and assay buffers (with all the same components as in the standard Tris homogenization and assay buffers).

\section{Urea denaturation}

Hepatopancreas homogenates were prepared as previously described and G6PDH susceptibility to urea denaturation was assessed by incubating samples of crude hepatopancreas extract from control and anoxic snails with different concentrations of urea (0-1 M) in homogenization buffer, $\mathrm{pH} 8.0$ for $24 \mathrm{~h}$ at $22^{\circ} \mathrm{C}$. After incubation, aliquots of sample were used to measure remaining G6PDH activity under standard assay conditions. 


\section{Effect of ions and other metabolites on G6PDH activity}

Sephadex G-50 filtered extracts of hepatopancreas from control and anoxic snails were used to assess the effects of $\mathrm{NaCl}, \mathrm{KCl}$, and $\mathrm{NH}_{4} \mathrm{Cl}$ on $\mathrm{G} 6 \mathrm{PDH}$ activity at concentrations up to $2 \mathrm{M}$ using standard assay conditions at $\mathrm{pH}$ 8.0. Comparable effects of selected metabolites on hepatopancreas G6PDH were evaluated for control and $24 \mathrm{~h}$ anoxic snails; metabolites included L-alanine, L-aspartic acid, phosphoenolpyruvate (PEP), AMP and succinate; assays were conducted at $\mathrm{pH} 6.5$ and 7.5.

\section{Temperature studies}

Maximal G6PDH velocities were measured at $5^{\circ} \mathrm{C}, 10^{\circ} \mathrm{C}, 15^{\circ} \mathrm{C}, 20^{\circ} \mathrm{C}, 23^{\circ} \mathrm{C}$, and $30^{\circ} \mathrm{C}$ and Arrhenius plots were constructed. The energy of activation $\left(E_{A}\right)$ of the enzyme was then calculated. To measure activities at the different temperatures, the microplate reader was placed in a Precision Low Temperature Incubator 815 and temperature was adjusted to the desired values. Microplates were placed into the spectrophotometer and allowed to equilibrate to the desired temperature for several minutes before the assay was commenced. A telethermometer was used to measure microplate well temperature before and after assay. Data were plotted as a function of mean well temperature at the beginning versus the end of the assay.

\section{In Vitro Incubations to Stimulate Endogenous Protein Kinases and Phosphatases}

To determine the effects of endogenous protein kinases and phosphatases on G6PDH in L. littorea hepatopancreas extracts from control and anoxic snails, incubations 
were conducted which stimulated the activities of specific endogenous protein kinases or protein phosphatases. Tissue extracts were prepared in standard homogenization buffer (also called STOP buffer). After centrifugation, $150 \mu 1$ aliquots of extract were incubated in $300 \mu 1$ of the specific incubation solution for $4 \mathrm{~h}$ at $4^{\circ} \mathrm{C}$. After incubation, samples were subjected to Sephadex G-50 gel filtration to remove metabolites that could interfere with the enzyme assay. $\mathrm{K}_{\mathrm{m}} \mathrm{G} 6 \mathrm{P}$ values were then determined in assays that used $10 \mu 1$ of incubation mixture. The specific incubation solutions used were as follows:

STOP: standard homogenization buffer

Base Buffer: $50 \mathrm{mM}$ Tris-HCl, pH 7.5, 10\% glycerol, $10 \mathrm{mM}$ 2-mercaptoethanol

\section{To stimulate protein kinases:}

PKA: base buffer $+1 \mathrm{mM}$ cAMP $+5 \mathrm{mM} \mathrm{ATP}+10 \mathrm{mM} \mathrm{MgCl}_{2}+30 \mathrm{mM} \mathrm{NaF}+$ $5 \mathrm{mM} \mathrm{Na}_{3} \mathrm{VO}_{4}$

PKG: base buffer $+1 \mathrm{mM} \mathrm{cGMP}+5 \mathrm{mM} \mathrm{ATP}+10 \mathrm{mM} \mathrm{MgCl} 2+30 \mathrm{mM} \mathrm{NaF}+$ $5 \mathrm{mM} \mathrm{Na}_{3} \mathrm{VO}_{4}$

PKC: base buffer $+1.3 \mathrm{mM} \mathrm{CaCl}_{2}+7 \mathrm{ug} / \mathrm{mL}$ PMA (phorbol 12-myristate 13-acetate) + $5 \mathrm{mM} \mathrm{ATP}+5 \mathrm{mM} \mathrm{MgCl} 2+30 \mathrm{mM} \mathrm{NaF}+5 \mathrm{mM} \mathrm{Na}_{3} \mathrm{VO}_{4}$

AMPK: base buffer $+1 \mathrm{mM}$ AMP $+5 \mathrm{mM}$ ATP $+10 \mathrm{mM} \mathrm{MgCl}_{2}+30 \mathrm{mM} \mathrm{NaF}+$ $5 \mathrm{mM} \mathrm{Na}_{3} \mathrm{VO}_{4}$

$\mathrm{Ca}^{+2} /$ Calmodulin Kinase (CaMK): base buffer $+1 \mathrm{U}$ of CaM activity/incubation tube + $1.3 \mathrm{mM} \mathrm{CaCl}_{2}+5 \mathrm{mM} \mathrm{ATP}+10 \mathrm{mM} \mathrm{MgCl}_{2}+30 \mathrm{mM} \mathrm{NaF}+5 \mathrm{mM} \mathrm{Na}_{3} \mathrm{VO}_{4}$

Total Kinase: base buffer + $1 \mathrm{mM} \mathrm{cAMP}+5 \mathrm{mM} \mathrm{ATP}+1 \mathrm{mM} \mathrm{cGMP}+1.3 \mathrm{mM} \mathrm{CaCl}_{2}$ $+7 \mathrm{ug} / \mathrm{mL}$ PMA (phorbol 12-myristate 13-acetate) $+1 \mathrm{mM} \mathrm{AMP}+1 \mathrm{U}$ of CaM 
activity/incubation tube $+10 \mathrm{mM} \mathrm{MgCl}+30 \mathrm{mM} \mathrm{NaF}+5 \mathrm{mM} \mathrm{Na}_{3} \mathrm{VO}_{4}$

\section{Tostimulate protein phosphatases}

PP1: base buffer + no ions (therefore no PP2B or PP2C activity) $+2.5 \mathrm{nM}$ okadaic acid (inhibits PP2A) $+5 \mathrm{mM} \mathrm{Na}_{3} \mathrm{VO}_{4}, 2 \mathrm{mM}$ EDTA, and $2 \mathrm{mM}$ EGTA

PP1 + PP2A: base buffer + no ions (no PP2B/PP2C activity) $+30 \mathrm{mM} \mathrm{Na}_{3} \mathrm{VO}_{4}+2 \mathrm{mM}$ EDTA + 2 mM EGTA.

Total Ser/Thr Phosphatases - (PP1+ PP2A): base buffer $+5 \mathrm{mM} \mathrm{MgCl}_{2}+5 \mathrm{mM}$ $\mathrm{CaCl}_{2}+5 \mathrm{mM} \mathrm{Na}_{3} \mathrm{VO}_{4},+1 \mu \mathrm{M}$ okadaic acid (inhibits both PP1/PP2A)

PP2B: base buffer $+5 \mathrm{mM} \mathrm{CaCl}_{2}+2 \mathrm{mM}$ EDTA (chelates $\mathrm{Mg}^{2+}$, inhibits PP2C) + $1 \mu \mathrm{M}$ okadaic acid (inhibits PP1/PP2A) $+5 \mathrm{mM} \mathrm{Na}_{3} \mathrm{VO}_{4}$

PP2C: base buffer $+5 \mathrm{mM} \mathrm{MgCl}_{2}+2 \mathrm{mM}$ EGTA (chelates $\mathrm{Ca}^{2+}$, inhibits PP2B) + $1 \mu \mathrm{M}$ okadaic acid (inhibits PP1/PP2A) $+5 \mathrm{mM} \mathrm{Na}_{3} \mathrm{VO}_{4}+1 \mathrm{nM}$ cypermethrin (inhibits PP2B).

Total PPase: base buffer $+5 \mathrm{mM} \mathrm{MgCl}_{2}+5 \mathrm{mM} \mathrm{CaCl}_{2}$

\section{Immunoprecipitation of Radiolabelled Phosphorylated G6PDH}

To confirm that incubations which stimulated protein kinases actually did transfer phosphate groups onto G6PDH, these incubations were repeated in the presence of ${ }^{32} \mathrm{P}$ ATP. Then the radiolabelled phopsho-G6PDH was immunoprecipitated using a G6PDH antibody and insoluble protein A.

For optimal detection of phosphorylation, studies began with the dephosphorylated enzyme. Tissue extracts were prepared and low molecular weight solutes were removed via Sephadex G-50 filtration. Extracts were then incubated for $4 \mathrm{~h}$ 
under conditions that promoted Total Phosphatase action, as described above. Then aliquots of dephosphorylated enzyme were incubated under either STOP or Total Kinase incubation conditions (as above) with the inclusion of $5 \mu \mathrm{Ci} \gamma-{ }^{32} \mathrm{P}-\mathrm{ATP}$ in a $300 \mu 1$ incubation volume, in addition to the regular amount of "cold" ATP. Following a $24 \mathrm{~h}$ incubation at $5^{\circ} \mathrm{C}, 60 \mu \mathrm{l}$ of Insoluble Protein A (from Sigma) suspension was added to the incubation volume and incubated overnight at $5^{\circ} \mathrm{C}$. Following this, samples were then centrifuged at $800 \mathrm{~g}$ in a Biofuge for $10 \mathrm{~min}$ to remove proteins that bind nonspecifically to Insoluble Protein A and the supernatants were removed. Supernatant samples were then incubated with $1 \mu \mathrm{g}$ of G6PDH primary antibody purchased from Sigma (rabbit antiG6PDH raised against antigen from Saccharomyces cerevisiae, stock prepared following manufacturer's directions) for $1 \mathrm{~h}$ at $5^{\circ} \mathrm{C}$ and then $60 \mu 1$ of IPA was added and incubated overnight, again at $5^{\circ} \mathrm{C}$. Along with the addition of G6PDH antibody, 50\% polyethylene glycol- 8000 was also added to the incubation tube to give a final PEG concentration of $5 \%$. Following this incubation, samples were centrifuged at $800 \mathrm{~g}$ for $10 \mathrm{~min}$. Supernatants were decanted and the pellets were resuspended in $100 \mu \mathrm{l}$ of $50 \mathrm{mM}$ Tris buffer, $\mathrm{pH}$ 7.5. This procedure was repeated for a total of 7 pellet washes. After the final wash, $5 \mu 1$ of the suspension was spotted on P81 paper and exposed to a phosphorscreen for $1 \mathrm{~h}$. Quantification of radioactivity was done using a Personal Molecular Imager ${ }^{\circledR}-\mathrm{FX}$ (BioRad).

\section{DEAE-Sephadex Elution Profiles}

DEAE-Sephadex columns $(5 \mathrm{~cm} \times 1 \mathrm{~cm})$ were equilibrated in standard column buffer (25 mM Tris-HCl, 5\% v:v glycerol, $5 \mathrm{mM}$ 2-mercaptoethanol, $12.5 \mathrm{mM} \mathrm{NaF}, 1.25$ 
mM EDTA, 1.25 mM EGTA, pH 7.0). A $300 \mu l$ aliquot of supernatant was added to the column, which was then washed with $10 \mathrm{~mL}$ of the same buffer to remove unbound proteins. Then the column was eluted with a linear gradient of $0-0.5 \mathrm{M} \mathrm{KCl}$ in $20 \mathrm{~mL}$ of column buffer. Extracts from control and $24 \mathrm{~h}$ anoxic hepatopancreas tissues were run separately. Approximately 50 fractions were collected with a Gilson FC203B fraction collector set at 5 drops per fraction. G6PDH activity was assayed under optimal assay conditions using $50 \mu \mathrm{l}$ from each fraction.

\section{Results}

\section{Optimization of experimental conditions}

The inclusion of EDTA and EGTA in the homogenization buffer did not have negative effects on the recoverable activity of G6PDH in the hepatopancreas from either control or $24 \mathrm{~h}$ anoxic snails. The inclusion of $\mathrm{NaF}$ improved recoverable activity as opposed to alternative phosphatase inhibitors such as B-glycerolphosphate which reduced recoverable activity. Thus, NaF, EDTA, and EGTA were used in the standard homogenizing buffer. Figure 2.1 displays the pH optima of hepatopancreas G6PDH from control and anoxic snails to be $\mathrm{pH}$ 8.0. Throughout the study, standard assays were performed at $\mathrm{pH} 8.0$, unless otherwise indicated. The $\mathrm{pH}$ curve also shows that G6PDH in anoxic snails is more active over a wider range of acidic pH values (Fig. 2.1).

\section{G6PDH kinetics}

Various enzyme parameters were assessed to demonstrate the kinetic differences between control and anoxic forms of G6PDH. For hepatopancreas G6PDH, the anoxic 
enzyme form had a $38 \%$ lower $K_{m}$ value for its G6P substrate compared with the control enzyme, whereas both the $\mathrm{K}_{\mathrm{m}} \mathrm{NADP}^{+}$and maximal velocity remained unchanged (Table 2.1). When the $\mathrm{pH}$ of the system was changed to 6.0 , a difference in maximal velocity was observed with the anoxic form having a $26 \%$ higher velocity in addition to a $38 \%$ lower $\mathrm{K}_{\mathrm{m}} \mathrm{NADP}^{+}$(Table 2.2).

\section{Urea denaturation}

The effects of urea denaturation on G6PDH activity was investigated by incubating the enzyme for $24 \mathrm{~h}$ at $22^{\circ} \mathrm{C}$ at concentrations of urea ranging from 0-1 M. It was observed that the anoxic form of G6PDH was more susceptible to urea denaturation, indicated by its $38 \%$ lower $\mathrm{I}_{50}$ urea value as compared to the control form (Table 2.1).

\section{Effect of various salts and other metabolites on G6PDH activity}

The effects of increasing $\mathrm{NaCl}, \mathrm{KCl}$ and $\mathrm{NH}_{4} \mathrm{Cl}$ concentrations on enzyme activity was also investigated and it was observed that these salts had relatively little effect on G6PDH. $\mathrm{I}_{50}$ values for all three salts were about $1 \mathrm{M}$ and did not change significantly between control and anoxic states (Table 2.1).

A large survey of the effects of various metabolites on hepatopancreas G6PDH from control and $24 \mathrm{~h}$ anoxic $L$. littorea was also performed at $\mathrm{pH} 6.5$ and $\mathrm{pH} 7.5$. After preliminary experiments were conducted, it appeared that none of the metabolites tested (AMP, alanine, aspartic acid, succinate and PEP) had either positive or negative effects on enzyme activity (data not shown). 


\section{Temperature studies}

Activation energies for G6PDH were determined from Arrhenius plots with activities measured between 5 and $30^{\circ} \mathrm{C}$. The relationship was linear over the range of temperatures tested for G6PDH from both control and anoxic tissues. The calculated activation energy, $E_{A}$, for G6PDH from control hepatopancreas was $27 \pm 3 \mathrm{KJ} / \mathrm{mol}$ which was not significantly different from the value for the enzyme from anoxic tissue, $22 \pm 3$ $\mathrm{KJ} / \mathrm{mol}$ (Table 2.1).

\section{In vitro incubations to assess G6PDH activity as a function of phosphorylation state}

Aliquots of crude extracts of hepatopancreas from control and anoxic snails were incubated for $4 \mathrm{~h}$ at $4^{\circ} \mathrm{C}$ under conditions that stimulate the activities of endogenous protein kinases or protein phosphatases and the effects on G6P substrate affinity $\left(\mathrm{K}_{\mathrm{m}}\right)$ were determined. Figure 2.2a shows the effects of specific protein kinase incubations on $\mathrm{K}_{\mathrm{m}}$ G6P. When incubated under conditions which stimulated PKA, PKC, PKG or AMPK, the anoxic form of G6PDH showed a significant increase in $\mathrm{K}_{\mathrm{m}} \mathrm{G} 6 \mathrm{P}$. For example, incubations that stimulated PKG increased the $\mathrm{K}_{\mathrm{m}} \mathrm{G6P}$ of anoxic G6PDH by $40 \%$ as compared to the STOP condition (that inhibited both kinase and phosphatase activities), elevating the $\mathrm{K}_{\mathrm{m}} \mathrm{G} 6 \mathrm{P}$ to a value very close to that of control G6PDH (Fig 2.2a). Stimulation of CaMK did not alter $\mathrm{K}_{\mathrm{m}} \mathrm{G} 6 \mathrm{P}$ values from anoxic snails and none of the kinase treatments had any effect on the $\mathrm{K}_{\mathrm{m}} \mathrm{G} 6 \mathrm{P}$ from control snails.

Conversely, in Figure 2.2b, the effect of specific protein phosphatases on $K_{m} G 6 P$ was investigated. The $\mathrm{K}_{\mathrm{m}}$ G6P value in preparations from anoxic snails was not affected 
by any of the incubation treatments that stimulated endogenous protein phosphatase activities. However, with control extracts, stimulation of PP1+PP2A-type activity and PP2C-type activity decreased the $\mathrm{K}_{\mathrm{m}} \mathrm{G} 6 \mathrm{P}$ by $57 \%$ and $41 \%$, respectively, reducing it to values seen during anoxia (Fig. 2.2b). Table 2.3 presents an overall summary of the incubation study indicating which protein kinases and phosphatases were responsible for the phosphorylation and dephosphorylation of G6PDH in hepatopancreas extracts.

\section{Immunoprecipitation of Radiolabelled Phospho-G6PDH}

To confirm that the above incubations actually did transfer phosphate groups onto G6PDH, the protein kinase incubations were run again, this time in the presence of $\gamma-{ }^{32} \mathrm{P}$ ATP. Then the radiolabelled phopsho-G6PDH was immunoprecipitated using a G6PDH antibody and insoluble protein A. Figure 2.3 displays the results of the radioactive immunoprecipitation in terms of relative intensity of the radioactive spots on P81 phosphocellulose paper. Control hepatopancreas extracts were first dephosphorylated by incubations under Total Phosphatase conditions and were then incubated with $\gamma_{-}{ }^{32} \mathrm{P}-\mathrm{ATP}$ under two conditions: STOP conditions that inhibit both kinases and phosphatases and Total Kinase conditions that promote the activity of all protein kinases. Figure 2.3 shows that there was a statistically significant $33 \%$ increase in radioactivity incorporated into the control form of G6PDH under Total Kinase conditions as compared with the respective STOP conditions.

\section{Ion exchange chromatography of high and low phosphate forms of G6PDH}

DEAE-Sephadex chromatography resolved two separate peaks of G6PDH activity 
from crude hepatopancreas extracts; one peak for control and the other for $24 \mathrm{~h}$ anoxic snails (Fig. 2.4). Peaks I and II appear to elute at approximately $0.13 \mathrm{M}$ and $0.28 \mathrm{M} \mathrm{KCl}$ respectively. 
Table 2.1. Kinetic parameters for G6PDH at $\mathrm{pH} 8.0$ from hepatopancreas of control and $24 \mathrm{~h}$ anoxic $L$. littorea

\begin{tabular}{|l|c|c|}
\hline & Control & 24 h Anoxic \\
\hline $\mathrm{K}_{\mathrm{m}} \mathrm{G} 6 \mathrm{P}(\mathrm{mM})$ & $0.097 \pm 0.006$ & $0.060 \pm 0.003^{*}$ \\
\hline $\mathrm{K}_{\mathrm{m}} \mathrm{NADP}^{+}(\mathrm{mM})$ & $0.117 \pm 0.006$ & $0.115 \pm 0.008$ \\
\hline $\mathrm{V}_{\max }(\mathrm{mU} / \mathrm{mg}$ soluble protein) & $30 \pm 1$ & $29.7 \pm 0.8$ \\
\hline Activation Energy, $\mathrm{E}_{\mathrm{A}}(\mathrm{KJ} / \mathrm{mol})$ & $27 \pm 3$ & $22 \pm 3$ \\
\hline $\mathrm{I}_{50}$ Urea $(\mathrm{mM})$ & $90 \pm 10$ & $56 \pm 3^{*}$ \\
\hline $\mathrm{I}_{50} \mathrm{NaCl}(\mathrm{M})$ & $0.99 \pm 0.05$ & $1.2 \pm 0.1$ \\
\hline $\mathrm{I}_{50} \mathrm{KCl}(\mathrm{M})$ & $1.32 \pm 0.09$ & $1.2 \pm 0.2$ \\
\hline $\mathrm{I}_{50} \mathrm{NH}{ }_{4} \mathrm{Cl}(\mathrm{M})$ & $0.9 \pm 0.1$ & $1.0 \pm 0.1$ \\
\hline
\end{tabular}

Assays were performed at $22^{\circ} \mathrm{C}$ and data are means $\pm \mathrm{SEM}, \mathrm{n}=4$ preparations from different animals. Kinetic constants were determined at optimal concentrations of ions or cosubstrates. * - Significantly different from the control value using the Student's t-test, $\mathrm{p}<0.05$. 
Table 2.2. Kinetic parameters for G6PDH at pH 6.0 from hepatopancreas of control and $24 \mathrm{~h}$ anoxic L. littorea

\begin{tabular}{|l|c|c|}
\hline & Control & 24 h Anoxic \\
\hline $\mathrm{K}_{\mathrm{m}} \mathrm{G} 6 \mathrm{P}(\mathrm{mM})$ & $0.41 \pm 0.04$ & $0.47 \pm 0.02$ \\
\hline $\mathrm{K}_{\mathrm{m}} \mathrm{NADP}^{+}(\mathrm{mM})$ & $0.19 \pm 0.02$ & $0.118 \pm 0.008^{*}$ \\
\hline $\mathrm{V}_{\max }(\mathrm{mU} / \mathrm{mg}$ soluble protein) & $19.8 \pm 0.6$ & $24.9 \pm 1.3^{*}$ \\
\hline
\end{tabular}

Assays were performed at $22^{\circ} \mathrm{C}$ and data are means $\pm S E M, n=4$ preparations from different animals. Kinetic constants were determined at optimal concentrations of cosubstrates. * - Significantly different from the control value using the Student's t-test, $\mathrm{p}<0.05$. 
Table 2.3: Summary of the incubation studies to investigate the regulation of hepatopancreas G6PDH under control and anoxic conditions of the L. littorea.

\begin{tabular}{|c|c|c|c|}
\hline $\begin{array}{c}\text { Critical Protein } \\
\text { Kinases }\end{array}$ & Effect & $\begin{array}{c}\text { Critical Protein } \\
\text { Phosphatases }\end{array}$ & Effect \\
\hline PKA, PKC, & Increase anoxic & PP1+PP2A, & Decrease control \\
PKG, AMPK & $\mathrm{K}_{\mathrm{m}}$ G6P & PP2C & $\mathrm{K}_{\mathrm{m}}$ G6P \\
\hline
\end{tabular}


Figure. 2.1. Determination of the optimal assay $\mathrm{pH}$ for G6PDH activity from hepatopancreas of control and $24 \mathrm{~h}$ anoxic L. littorea. A $50 \mathrm{mM}$ Bis-Tris Propane buffer was used for $\mathrm{pH}$ conditions 6.0-9.0 and a CAPS buffer was used for $\mathrm{pH}$ conditions 9.511.0. Assays were run at $23^{\circ} \mathrm{C}$. Data are means $\pm S E M, n=4$ trials on independent preparations of enzyme. 
Figure 2.1

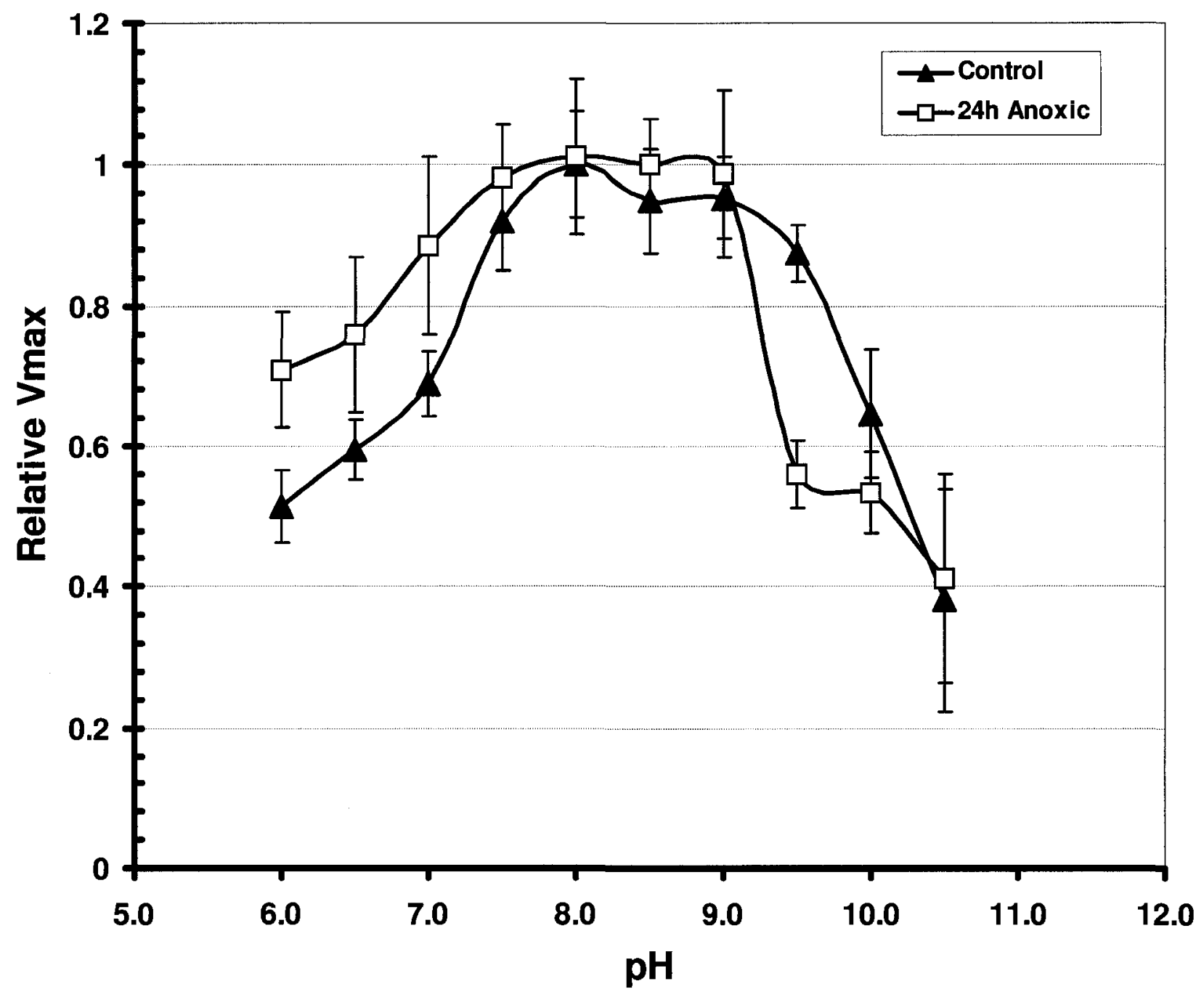


Figure 2.2. Effects of in vitro incubations to stimulate the activities of (A) protein kinases or (B) protein phosphatases on the $\mathrm{K}_{\mathrm{m}} \mathrm{G6P}$ of hepatopancreas G6PDH from aerobic control and $24 \mathrm{~h}$ anoxic $L$. littorea. Crude extracts were incubated for $4 \mathrm{~h}$ at $4^{\circ} \mathrm{C}$ before assay at room temperature. Data are means $\pm \mathrm{SEM}, \mathrm{n}=3$. $a$ - Significantly different from the corresponding STOP value using the Dunnett's test, $P<0.05 . b-$ Significantly different from the corresponding control value using the Dunnett's test, $P<0.05$. 
Figure 2.2

A

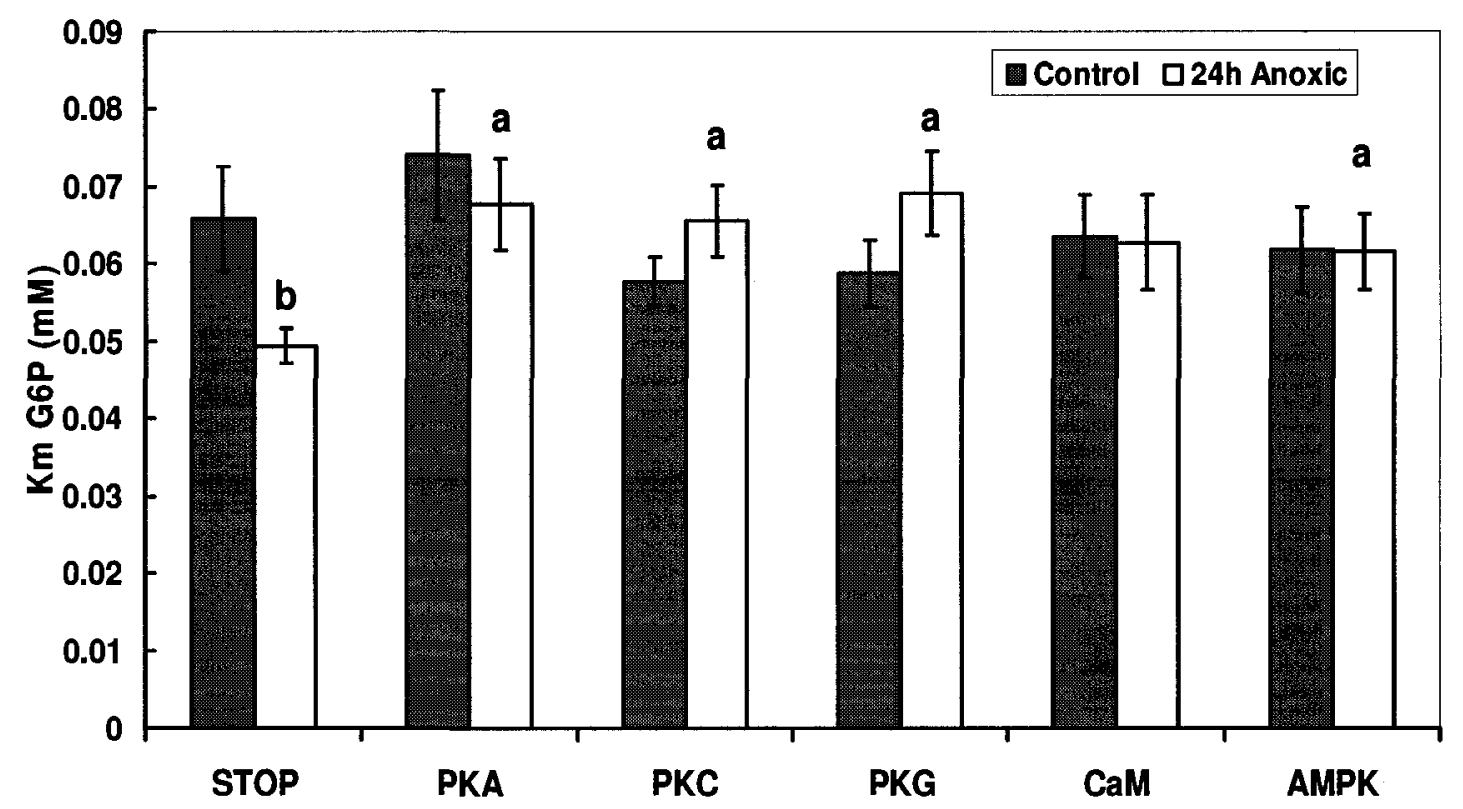

B

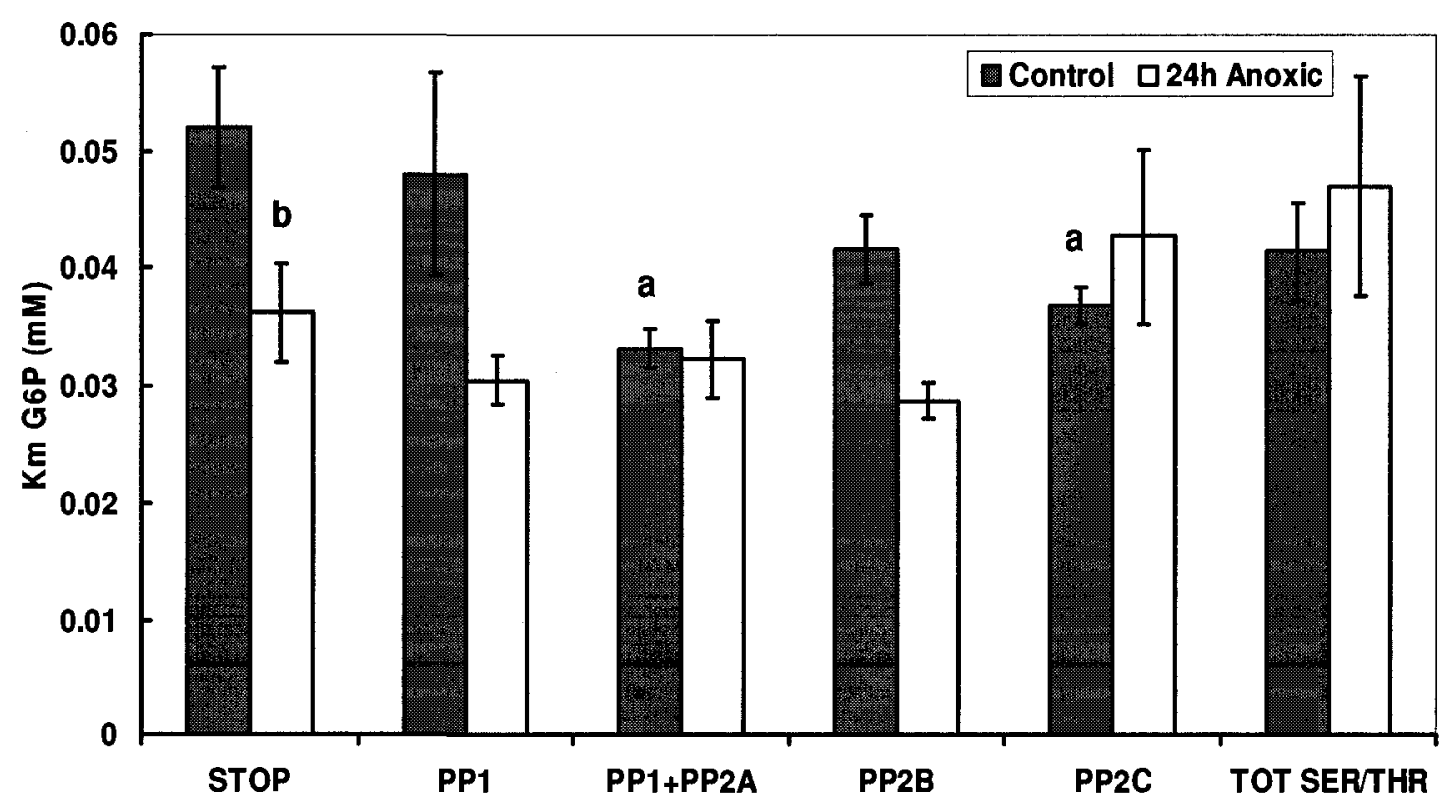


Figure 2.3. Results of the radioactive immunoprecipitation of G6PDH from control hepatopancreas of $L$. littorea. Relative intensities of radioactivity following in vitro incubations of the control form of G6PDH under conditions that stimulated the activities of all protein kinases (Total Kinase) versus conditions that inhibited all kinases and phosphatases (STOP); conditions for both are defined in the Materials and Methods. Data are means $\pm \mathrm{SEM}, \mathrm{n}=3$ determinations on separate preparations of enzyme. $a$ Significantly different from the corresponding STOP value using Student's t-test, $P<0.05$. 
Figure 2.3

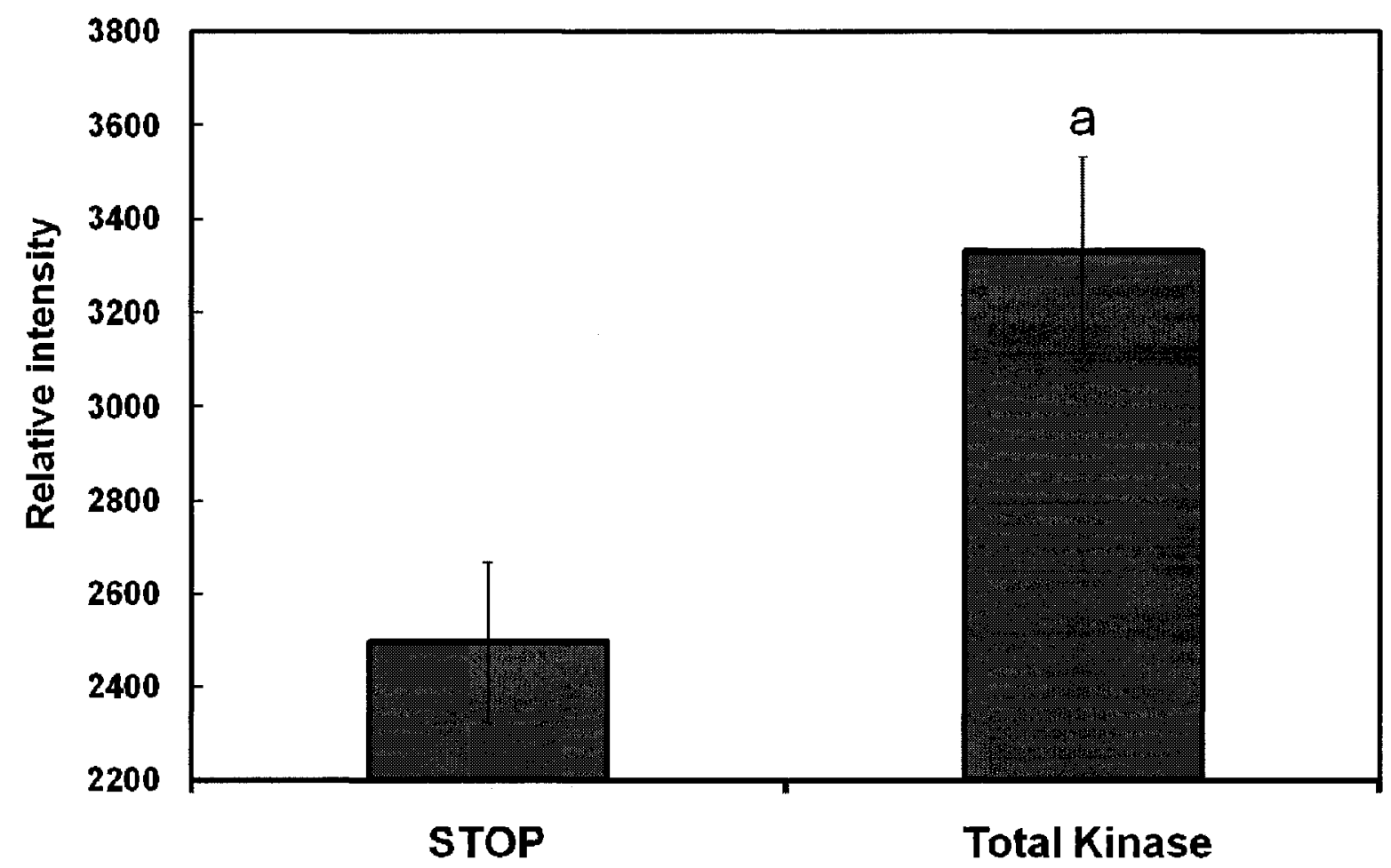


Figure 2.4. DEAE-Sephadex elution profiles for G6PDH activity from hepatopancreas of control and $24 \mathrm{~h}$ anoxic $L$. littorea. Profiles are representative of three independent determinations for each condition. Activities are expressed relative to the highest activity fraction. Peaks I and II eluted at increasingly higher $\mathrm{KCl}$ concentrations respectively, within a 0-0.5 M KCl salt gradient, $\mathrm{pH} 7.0$. 
Figure 2.4

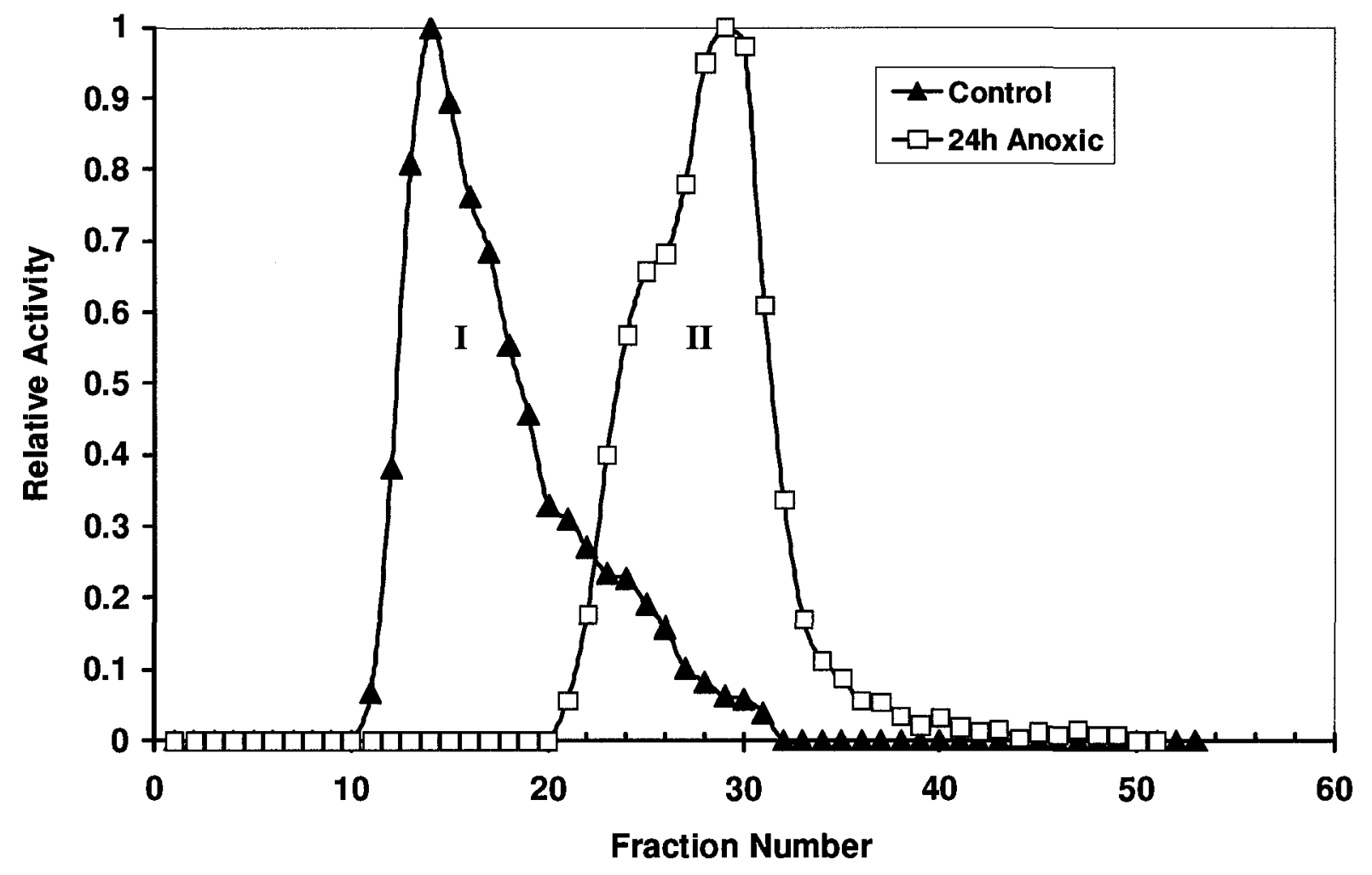


Figure 2.5. Representative figure showing possible native phosphorylation states of G6PDH in the hepatopancreas of $L$. littorea, based on the results from the in vitro protein kinase and phosphatase incubations. 
Figure 2.5

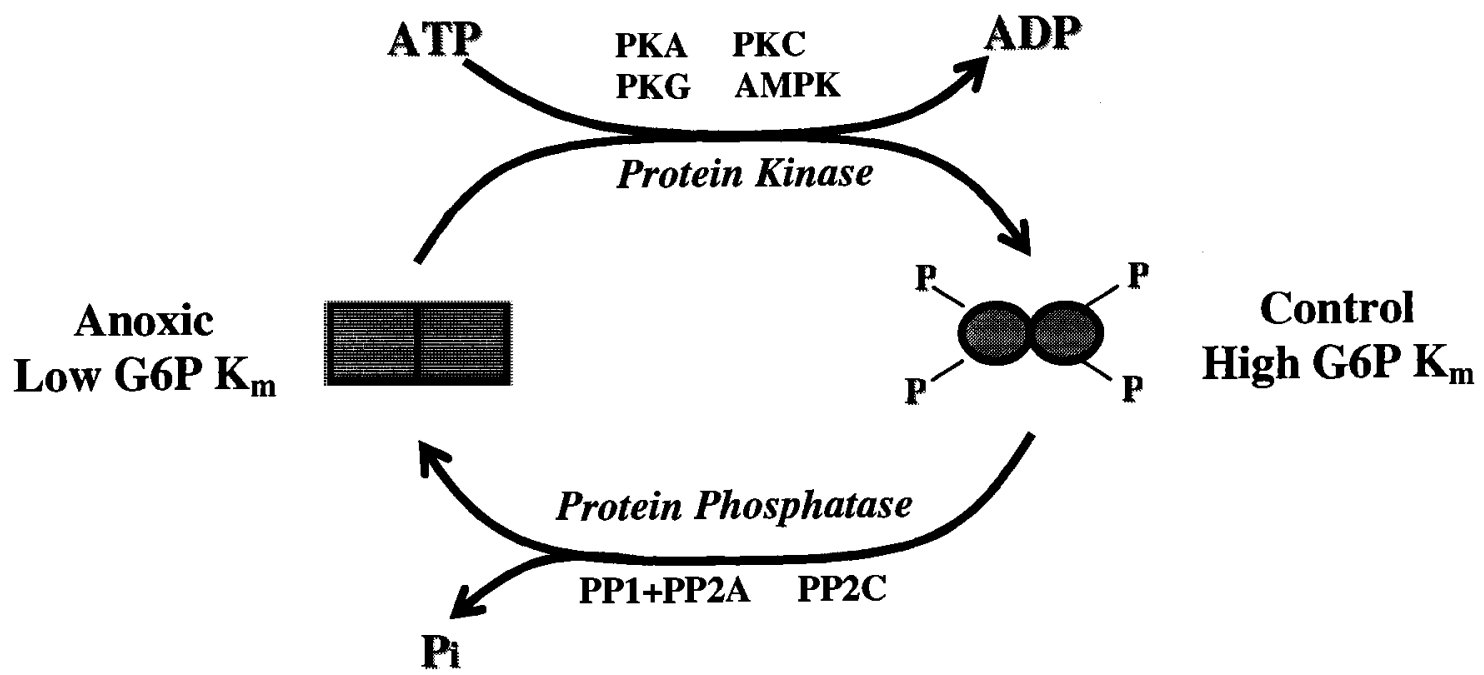




\section{Discussion}

G6PDH from the hepatopancreas of the marine mollusc $L$. littorea is subject to reversible phosphorylation and the data suggest that this mechanism underlies the anoxiainduced changes in activity and kinetic properties of the enzyme. This is one of the first cases in which phosphorylation control of a pentose phosphate cycle enzyme has been implicated as a component of natural hypometabolism (Ramnanan and Storey, 2006a). This suggests that pentose phosphate pathway flux is another of the metabolic functions that are targeted for coordinated control in animals switching between control and anoxic states (Ramnanan and Storey, 2006a). The central role of the liver, or liver-like organs of animals, in functions including biosynthesis, antioxidant defense and xenobiotic detoxification may mean that regulation of $\mathrm{G} 6 \mathrm{PDH}$ in the hepatopancreas is particularly important and is specifically targeted for regulatory control during hypometabolism.

Several of the properties of hepatopancreas G6PDH differed significantly between control and anoxic states. The anoxic form of G6PDH was overall more active at acidic $\mathrm{pH}$ conditions, as indicated by its greater maximal velocity and lower $\mathrm{K}_{\mathrm{m}} \mathrm{NADP}^{+}$, compared to the control form in assays at pH 6.0 (Fig. 2.1, Table 2.2). This is beneficial to the snail experiencing anoxia because intracellular $\mathrm{pH}$ decreases under anoxic conditions as a result of the accumulation of acidic anaerobic end-products such as lactate and succinate (Ellington 1983a; Ellington, 1983b; Pörtner et al., 1984; Walsh et al., 1984; Russell and Storey, 1995). In early stages of anoxia, the pyruvate produced by glycolysis in the $L$. littorea is converted to alanine in a reaction that is coupled with aspartate conversion to oxaloacetate; oxaloacetate is then metabolized to succinate in a reversal of several steps of the Krebs cycle, including the ATP-generating fumarate reductase 
reaction (Eberlee and Storey, 1988; de Zwaan, 1977). As anoxia is extended and aspartate pools become depleted, glycolytic carbon is shunted directly into reactions of succinate synthesis; and it is only under prolonged anaerobiosis where volatile end-products such as acetate and propionate are produced (Eberlee and Storey, 1988). Therefore, having an enzyme that is more active at acidic $\mathrm{pH}$ conditions is valuable to the anoxic snail because it is under anoxic conditions where the snail will have to combat cellular acidosis because of the accumumulation of anaerobic end-products.

Furthermore, anoxic forms of G6PDH displayed a lower $\mathrm{K}_{\mathrm{m}}$ for G6P than the control enzyme (Table 2.1). This can be explained in terms of the role of the PPP under anoxia. One major function of the PPP, and specifically G6PDH, is to produce reducing equivalents of NADPH which can be used to combat oxidative stress upon returning to normoxia (Ramnanan and Storey, 2006a). Therefore, it seems logical for the enzyme, under stress conditions, to have a stronger affinity for one of its substrates, since the reaction it catalyzes produces NADPH. Also a previous study found that G6P substrate levels were reduced by $>67 \%$ in hepatopancreas of snails undergoing estivation, another environmental stress triggering hypometabolism (Churchill and Storey 1989). So the increase in substrate affinity of G6PDH during anoxia in $L$. littorea could help to realign enzyme activity with substrate availability (Brooks and Storey, 1989). Interestingly, $O$. lactea hepatopancreas PFK-1, the key regulatory enzyme of glycolysis, showed the opposite response during stress. PFK-1 affinity for its substrate, fructose-6-phosphate, was significantly reduced during estivation and these changes in enzyme properties were again traced to phosphorylation of the enzyme (Whitwam and Storey, 1991). Glycolysis and the PPP are two of the main pathways competing for G6P in cells. Previous studies 
have shown that stress-responsive changes in the properties of $O$. lactea hepatopancreas regulatory enzymes (PFK and G6PDH) suggest that carbohydrate flux through the pentose phosphate cycle may be relatively enhanced during hypometabolism compared with carbohydrate flow through glycolysis. Therefore, it appears that the response of G6PDH to anoxia in the hepatopancreas of $L$. littorea is similar to that found in $O$. lactea hepatopancreas undergoing estivation.

Arrhenius activation energies were calculated from the maximal velocities of G6PDH at various temperatures. The activation energy is essentially the energy barrier which must be overcome, in order for a specific chemical reaction to occur. A change in enzyme phosphorylation state which alters enzyme conformation, could cause a change in activation energy if the conformational changes affected the functioning of the active site. Since the $\mathrm{K}_{\mathrm{m}} \mathrm{G} 6 \mathrm{P}$ was significantly lower in anoxic versus control snails, a change in activation energy might occur. However, the results showed that the activation energy of G6PDH remained constant between control and stress states (Table 2.1).

G6PDH from control and anoxic snails differed significantly in another measure of enzyme conformational change: the extent of urea-dependent protein unfolding as evidenced by urea inhibition of activity. The anoxic form of G6PDH appeared to be more susceptible than the control form to urea denaturation, as indicated by its lower $I_{50}$ value for urea (Table 2.1). The difference in G6PDH stability to urea denaturation may derive from small differences in protein structure between control and stress states. Differential sensitivity to urea denaturation has been previously documented in comparisons of enzymes from control versus hypometabolic states (Ramnanan and Storey, 2006a; Abnous and Storey, 2007). Increased urea susceptiblility under hypometabolic states has 
been linked to a greater flexibility in enzyme structure, which is a valuable asset under stress conditions (Abnous and Storey, 2007). Therefore, since the intertidal snail encounters many environmental stresses such as anoxia, freezing and acidosis, it is plausible that the form of G6PDH present under stress conditions should have a greater flexibility since it would aid the enzyme in maintaining its function over an everchanging cellular environment.

The data for the effects of high salt concentrations $\left(\mathrm{NaCl}, \mathrm{KCl}, \mathrm{NH}_{4} \mathrm{Cl}\right)$ on hepatopancreas G6PDH activity appear logical when you consider the habitat of $L$. littorea. Since $L$. littorea are marine snails, they have adapted to handle high ion concentrations in their body fluds without significantly diminishing their enzyme activity (Somero and Bowlus, 1983). Hence, it was not surprising that G6PDH showed very little inhibition by these salts with $\mathrm{I}_{50}$ values that were all around $1 \mathrm{M}$. Also, the salts tested were rather simple salts and if more harsh, chaotropic salts had been used, such as guanidine hydrochloride $\left(\mathrm{CH}_{6} \mathrm{ClN}_{3}\right)$, inhibitory effects may have been observed. Chaotropic salts are especially known to disrupt non-binding forces such as Van der Waals, hydrophobic effects, and hydrogen bonding (Madou, 2002).

Given that there were significant stable differences in some of the kinetic properties of hepatopancreas G6PDH between control and anoxic states, I investigated the possibility that these were due to covalent modification of the enzyme, specifically to reversible protein phosphorylation. In vitro incubations that stimulated the activities of four endogenous protein kinases (PKA, PKC, PKG and AMPK) all increased the $\mathrm{K}_{\mathrm{m}} \mathrm{G6P}$ of hepatopancreas G6PDH from anoxic snails (Fig. 2.2a). The increase in $K_{m} G 6 P$ stimulated by protein kinase action suggests that phosphorylation is inhibitory for 
G6PDH activity. It has already been shown that PKA phosphorylates G6PDH in the muscle of the mollusc, A. cygnea (Kuznetsova and Plesneva, 2001) and previous studies of G6PDH have shown that PKA-mediated phosphorylation inhibits G6PDH activity (Costa Rosa et al., 1995; Zhang et al., 2000; Xu et al., 2005). Therefore one or more of the four kinases could mediate the anoxia-induced response of G6PDH in vivo.

Oppositely, in vitro incubations that stimulated the activities of endogenous protein phosphatases affected the control form of $L$. littorea G6PDH. Incubations under conditions that stimulated PP1+PP2A-type or PP2C-type phosphatase action on control G6PDH, reduced $\mathrm{K}_{\mathrm{m}} \mathrm{G6P}$ to values similar to the anoxic form (Fig. 2.2b). Therefore, one or more of these phosphatases may be the endogenous phosphatases responsible for G6PDH dephosphorylation during the entry of L. littorea into anoxia.

Taking results from both the kinase and phosphatase incubations into consideration, we can propose that the control form of hepatopancreas G6PDH is the high phosphate form whereas the anoxic enzyme is the lower phosphate form. Figure 2.5 displays a representative figure of possible native phosphorylation states of G6PDH from both control and anoxic hepatopancreas tissue, based on the results from the in vitro protein kinase and phosphatase incubations. Therefore, it appears that the transition between the control and anoxic forms of G6PDH is regulated by reversible phosphorylation. The high-phosphate, high $\mathrm{K}_{\mathrm{m}} \mathrm{G6P}$ control version of G6PDH is affected by $\mathrm{PP} 1+\mathrm{PP} 2 \mathrm{~A}$ and $\mathrm{PP} 2 \mathrm{C}$. Under anoxic conditions, one or more of these phosphatases reduce the phosphorylation state of control G6PDH, converting it to the lower $K_{m} G 6 P$, low-phosphate anoxic version. Oppositely, the action of protein kinases on the anoxic form of G6PDH reconverts the enzyme to the high $\mathrm{K}_{\mathrm{m}} \mathrm{G6P}$ form that is characteristic of 
the aerobic control state; candidates for this action include PKA, PKC, PKG or AMPK (Fig. 2.5).

To confirm that the incubation experiments actually did result in the transfer of phosphate groups onto G6PDH, the protein kinase incubations were run again in the presence of $\gamma_{-}{ }^{32} \mathrm{P}-\mathrm{ATP}$. Radiolabelled phopsho-G6PDH was then immunoprecipitated using a G6PDH antibody and insoluble protein A. These experiments demonstrated that G6PDH from control hepatopancreas (after initial dephosphorylation) incorporated high amounts of ${ }^{32} \mathrm{P}$ when incubated under conditions that stimulated protein kinases (Total Kinase) as compared with incubations under STOP conditions (Fig. 2.3). Radioactive immunoprecipitation thus validates the in vitro incubation results and demonstrates that G6PDH from the hepatopanceas has the ability to be phosphorylated, which further supports the fact that G6PDH is regulated by reversible protein phosphorylation in $L$. littorea.

With the knowledge gained from the protein kinase/phosphatase incubations, there appeared to be two forms of G6PDH in snail hepatopancreas extracts which differed in both phosphorylation state and kinetic properties. To confirm the presence of two separate enzyme forms, enzyme extracts were separated on a DEAE-Sephadex column at $\mathrm{pH} 7.0$ using a salt gradient of $0-0.5 \mathrm{M} \mathrm{KCl}$. The elution profiles show that G6PDH from both control and anoxic states eluted in one large and discrete peak but that these peaks were well separated by up to 14 fractions (Fig. 2.4a). The control form always eluted first at a low salt concentration whereas the anoxic form eluted at a higher salt concentration. It should be noted that the process of elution off of a DEAE-Sephadex column is a matter of disrupting the ionic charge holding the enzyme to the column. The 
phosphate functional group is commonly known to add a more negative charge to an enzyme and thus allow it to become more tightly bound to the positive DEAE beads; but this is not the only negatively charged group (carboxylates, for instance), which may contribute to the overall charge state of an enzyme. Furthermore, ion-exchange columns predominantly deal with only the charge on the outer surface of the enzyme. Perhaps the control form of G6PDH may have less negatively charged groups on its outer surface than the anoxic form, which would result in it being eluted off the column first, at a weaker ionic strength.

Also, it is a definite possibility that phosphorylation may alter the conformation of an enzyme in order to reveal more positively charged side chains on its outer surface layer. This has been shown to be the case for the cAMP response element binding protein (CREB), which increases in positive net surface charge as a result of phosphorylation (Bullock and Habener, 1998). Phosphorylation-induced conformational changes could cause an increase in net surface charge by either exposing basic amino acids (such as arginine or lysine) or masking anionic, acidic amino acids (such as aspartic acid or glutamic acid). Hence, the important point here is that the ion-exchange columns revealed that there are two physically distinct forms of the enzyme. Since the incubation studies indicated that the control form of G6PDH was the more highly phosphorylated version, the addition of phosphate groups may have caused the enzyme to change its structure, thereby exposing more positive charges on its surface, which would result in the control version being eluted off the ion-exchange column first.

As mentioned in the introduction, anoxia-tolerant animals, such as the $L$. littorea express a diverse array of biochemical adaptations that sustain their survival during 
oxygen deprivation, one of these being antioxidant protection. Further, animals undergoing anoxia also have effective antioxidant defenses to deal with the oxidative stress that might occur with the reintroduction of oxygen into their tissues. After prolonged periods without oxygen, its sudden reintroduction should create a danger of ROS overgeneration and oxidative damage to cells. As mentioned earlier, the PPP has multiple functions in cells, such as being the primary source of NADPH reducing power for most biosynthetic reactions (e.g. fatty acid synthesis) and for the production of reduced forms of antioxidants (e.g. glutathione, thioredoxin) (Ramnanan and Storey, 2006a). Carbon entry into the PPP is gated by G6PDH, the first of two NADPHgenerating reactions in the pathway; while carbon shuffling within the PPP also produces ribose-5-phosphate for nucleotide synthesis as well as 3-7 carbon sugars or sugar phosphates for other uses (Storey and Storey, 2007).

Therefore, it is proposed that the prominent function of G6PDH in antioxidant defense was the reason for the anoxia-responsive modification of the enzyme. Improved antioxidant defenses are a common theme across all forms of hypometabolism and since the crux of antioxidant defense is NADPH reducing power, the key role of G6PDH in gating the PPP can be appreciated. Notably, G6PDH activity is elevated in a number of systems, ranging from yeast to humans, in response to oxidative stress (Slekar et al., 1996; Ursini et al., 1997; Larini et al., 2004) whereas inhibited and/or reduced G6PDH activity has been correlated with reduced antioxidant defense capacities, ROS-related cellular damage, and ROS-induced cell death (Tian et al., 1999; Sailaja et al., 2003, Kimura et al., 2004).

In summary, the present study shows that G6PDH from L. littorea hepatopancreas 
is a phosphoprotein and that entry into the hypometabolic state of anoxia results in a strong increase in the dephosphorylated form of G6PDH. The properties of dephosphoG6PDH are consistent with a more active enzyme which may favour enhanced carbon flow through the pentose phosphate cycle during anoxia to sustain NADPH production for antioxidant defense. The data provides one of the first demonstrations of coordinated regulation of the pentose phosphate cycle between active and hypometabolic states and implicates specific protein kinases (PKA, PKC, PKG, AMPK) and protein phosphatases (PP1+PP2A, PP2C) as responsible for $\mathrm{G} 6 \mathrm{PDH}$ regulation. 


\section{CHAPTER 3}

\section{Hexokinase regulation in the hepatopancreas and foot muscle of the anoxia-tolerant marine mollusc, $L$. littorea}




\section{Introduction}

Hexokinase (HK) (E.C. 2.7.1.1) catalyzes the first reaction of glycolysis:

$$
\text { D-glucose + ATP } \rightarrow \text { D-glucose-6-phosphate + ADP }
$$

The reaction catalyzes the addition of the $\gamma$-phosphoryl group of ATP to a hexose, which is most often glucose. The phosphorylation of glucose, a key energy source, decreases the intracellular pool of free glucose, which permits facilitated glucose entry into cells. By catalyzing the ATP-dependent phosphorylation of glucose to yield glucose6-phosphate (G6P), hexokinase controls the first committed step of glucose metabolism and initiates all major pathways of glucose utilization (Robey and Hay, 2006). G6P is a key branch-point metabolite since it can enter a variety of pathways such as glycolysis to generate ATP, the pentose phosphate pathway to produce NADPH and sugar phosphates, or glycogen synthesis to store fuel for future use (Wilson, 2003).

$\mathrm{HK}$ is a monomer with a molecular weight of approximately $100 \mathrm{kDa}$ and is strongly regulated by both of its reaction products in both mammalian and insect systems (Wilson, 1973; Magnani et al, 1982; Purich et al, 1973; Storey, 1980). In mammals, hexokinase has four isozymes (HK I-IV) which differ in both subcellular and tissue distribution (González et al., 1964; Katzen and Schimke, 1965). Glucokinase (HK IV) is a liver-specific isoform with a high $\mathrm{K}_{\mathrm{m}}$ glucose; whereas the other three isozymes have low $\mathrm{K}_{\mathrm{m}}$ glucose values and can be separated by ion exchange chromatography and isoelectric focusing (González et al., 1964; Katzen and Schimke, 1965). Differential transcriptional regulation of these isozymes may allow HK to be selectively expressed in particular tissues and differentially involved in various metabolic applications (Wilson, 1997). Some vertebrate HK isozymes can bind to the outer mitochondrial membrane and 
this binding is dependent on a hydrophobic $\mathrm{N}$-terminal sequence that selectively targets $\mathrm{HK}$ to the porin that is located in contact sites on the mitochondria (Polakis and Wilson, 1985).

Earlier studies involving anoxia-tolerant gastropod molluscs (L. littorea and Busycon canaliculatum) have demonstrated that the ATP-producing pathways of carbohydrate catabolism are suppressed during anoxia, via regulatory controls on ratelimiting enzymes including GP, PFK-1, PFK-2 and PK (Brooks and Storey, 1990; Brooks and Storey, 1991; Bosca and Storey, 1991; Storey, 1993). The primary mechanism implicated in the reversible control of these enzymes was reversible protein phosphorylation (Storey, 1993). Furthermore, it has been demonstrated in yeast, Saccharomyces cerevisiae, that the specific role of hexokinase PII in the glucose response is mediated by phosphorylation-dephosphorylation and hexokinase is additionally required for glucose signaling (Randez-Gil et al., 1998). Hexokinase has also been shown to be phosphorylated on its tyrosine residues in rat brain mitochondria (Lewandrowskia et al., 2008). It has been shown recently that mammalian HK is regulated by reversible phosphorylation and implicated as a component of metabolic rate depression in a system of natural hypometabolism (Abnous and Storey, 2008). The present study examines HK regulation in the hepatopancreas and foot muscle of the anoxia-tolerant marine mollusc, $L$. littorea. The foot muscle is involved in locomotion while the hepatopancreas makes up the majority of the visceral mass and is a main site for important metabolic functions such as protein synthesis, gluconeogenesis, glycogenolysis and other specific roles in digestion and excretion (Curtis and Barnes, 1989). For each tissue, there are two possibilities that might be predicted for the 
regulation of $\mathrm{HK}$ in this anoxia-tolerant mollusc. One possibility is that $\mathrm{HK}$ activity is suppressed in conjunction with the general metabolic rate depression experienced under anoxia. The other possibility is that HK activity is maintained or perhaps even enhanced because during anoxia, anaerobic carbohydrate catabolism must supply all the energy requirements of the cell. Furthermore, the regulation of HK may be tissue-specific and related to the different needs for HK function in the hepatopancreas and foot muscle. Hence, I predicted that HK would be differentially regulated under anoxia and that the mechanism responsible would be reversible protein phosphorylation.

\section{Methods and Materials}

\section{Animals}

Experimental treatment of $L$. littorea was performed as previously described in Chapter 2.

\section{Preparation of tissue extracts}

Preparation of soluble extracts of both hepatopancreas and foot muscle tissue as well as Sephadex G-50 gel filtration of crude supernatants were performed as previously described in Chapter 2.

\section{Hexokinase assay}

Hexokinase activity was assayed at $340 \mathrm{~nm}$ using a Thermo Labsystems Multiskan Spectrum Microplate Spectrophotometer (kinetic mode, reading interval $=21$ 
s). Optimum assay conditions for both tissues were $2 \mathrm{mM} \mathrm{Mg} \cdot \mathrm{ATP}$ (with $3.2 \mathrm{mM}$ additional $\mathrm{MgCl}_{2}$ ), $2 \mathrm{mM}$ glucose, $0.5 \mathrm{mM} \mathrm{NAD}^{+}$and 0.25 units of G6PDH (from Leuconostoc mesenteroides recombinant, expressed in Escherichia coli) coupling enzyme in $50 \mathrm{mM}$ Tris- $\mathrm{HCl}$ assay buffer, $\mathrm{pH} 7.5$. Reactions were initiated by adding $30 \mu \mathrm{l}$ of enzyme extract to a $200 \mu \mathrm{L}$ total reaction volume in the microplate well. Microplate Analysis (MPA) and Kinetics 3.51 computer programs were used to analyze the data. One unit of HK activity is defined as the amount of enzyme that produces $1 \mu \mathrm{mol}$ G6P per minute at $22^{\circ} \mathrm{C}$. Activities are reported in $\mathrm{mU} / \mathrm{mg}$ soluble protein. Soluble protein was quantified using the Coomassie blue dye binding method and the Bio-Rad prepared reagent with a standard curve of bovine serum albumin.

\section{Enzyme studies}

The effect of $\mathrm{pH}$ on $\mathrm{HK}$ activity from hepatopancreas and foot muscle was assessed over a $\mathrm{pH}$ range from 6.0 to 9.0 using $50 \mathrm{mM}$ imidazole buffer for $\mathrm{pH}$ values 6.0-7.5, $50 \mathrm{mM}$ Tricine buffer for $\mathrm{pH} 8.0-8.5$, and $50 \mathrm{mM}$ CHES buffer for $\mathrm{pH} 9.0$. Effects of various ions on HK activity were assessed using Sephadex G-50 filtered extracts of hepatopancreas and foot muscle from control and $24 \mathrm{~h}$ anoxic snails. $\mathrm{NaCl}, \mathrm{KCl}$, and $\mathrm{NH}_{4} \mathrm{Cl}$ were tested at concentrations up to $2 \mathrm{M}$ using standard assay conditions at $\mathrm{pH} 8.0$.

Urea denaturation of hepatopancreas and foot muscle HK was evaluated using crude tissue extracts that were incubated with urea at concentrations from $0-2 \mathrm{M}$ in homogenization buffer, $\mathrm{pH} 8.0$ for $24 \mathrm{~h}$ at $22^{\circ} \mathrm{C}$. After incubation, remaining HK activity was measured under standard assay conditions. 


\section{In Vitro Incubations to Stimulate Endogenous Protein Kinases and Phosphatases}

In vitro protein kinase and protein phosphatase incubations for both hepatopancreas and foot muscle extracts were performed as previously described in Chapter 2, with the following exceptions:

After centrifugation, $300 \mu 1$ aliquots of extract were incubated in $600 \mu 1$ of the specific incubation solution for $4 \mathrm{~h}$ at $4^{\circ} \mathrm{C}$. After the incubation period, aliquots $(30 \mu \mathrm{l})$ of filtered incubate were then used to measure $K_{m}$ values for glucose and ATP of hepatopancreas and foot muscle HK, respectively.

\section{Immunoprecipitation of Radiolabelled Phosphorylated HK}

Incubations of hepatopancreas and foot muscle extracts in the presence of ${ }^{32} \mathrm{P}$ ATP and subsequent immunoprecipitation of ${ }^{32} \mathrm{P}-\mathrm{HK}$ were performed as previously described in Chapter 2, with the following exceptions:

The addition of $50 \%$ polyethylene glycol- 8000 was omitted and in place of the G6PDH primary antibody, $1 \mu \mathrm{g}$ of HK primary antibody from Santa Cruz was used (HK goat polyclonal IgG raised against muscle $\mathrm{HK}$ isozyme II, stock prepared following manufacturer's directions).

\section{DEAE-Sephadex Elution Profiles}

DEAE-Sephadex column chromatography for both hepatopancreas and foot muscle extracts was performed as previously described in Chapter 2, with the following exceptions:

The column was eluted with a linear gradient of $0-2 \mathrm{M} \mathrm{KCl}$ in $40 \mathrm{~mL}$ of column 
buffer. For hepatopancreas, extracts from control and anoxic conditions were run separately whereas for foot, extracts from both conditions were combined and run simultaneously. Approximately 60 fractions were collected with a Gilson FC203B fraction collector set at 10 drops per fraction.

\section{Results}

\section{Optimization of experimental conditions}

The inclusion of EDTA and EGTA in the homogenization buffer did not have negative effects on the recoverable activity of HK in hepatopancreas and foot muscle extracts from either control or $24 \mathrm{~h}$ anoxic snails. The inclusion of $\mathrm{NaF}$ improved recoverable activity whereas an alternate phosphatase inhibitor ( $\beta$-glycerolphosphate) reduced recoverable activity. Thus, $\mathrm{NaF}$, EDTA, and EGTA were used in the standard homogenizing buffer. Figure 3.1 displays the $\mathrm{pH}$ optima of hepatopancreas HK from control and anoxic snails to be $\mathrm{pH} 7.5$; the same was observed for foot muscle HK (data not shown). Hence, throughout the study, standard assays were performed at $\mathrm{pH} 7.5$, unless otherwise stated. The $\mathrm{pH}$ curve also shows that $\mathrm{HK}$ in anoxic snails is more active over a wider range of $\mathrm{pH}$ values (Fig. 3.1).

\section{Hexokinase kinetics}

Kinetic properties of HK from L. littorea hepatopancreas are shown in Table 3.1. The anoxic enzyme had a maximum velocity which was just $52 \%$ of the control value. However, anoxic $\mathrm{HK}$ had a higher affinity for glucose, with a $\mathrm{K}_{\mathrm{m}}$ glucose that was $36 \%$ lower than the control value (Table 3.1). $\mathrm{K}_{\mathrm{m}}$ ATP did not differ between the two states. 
Comparable kinetic parameters for foot muscle HK are shown in Table 3.2. The anoxic enzyme showed a $38 \%$ lower maximum velocity and a 2.3 -fold higher $K_{m}$ ATP than the control enzyme but did not differ from control $\mathrm{HK}$ in its $\mathrm{K}_{\mathrm{m}}$ glucose (Table 3.2). For both the hepatopancreas and foot muscle homogenates, assays of the pellet found no detectable HK activity (data not shown).

\section{Urea denaturation}

The effects of urea denaturation on HK activity were investigated by incubating the enzyme for $24 \mathrm{~h}$ at $22^{\circ} \mathrm{C}$ in the presence of different concentrations of urea ranging from $0-2 \mathrm{M}$ and then assaying remaining enzyme activity. $\mathrm{I}_{50}$ values for urea (the concentration that reduced activity by $50 \%$ ) were calculated. These values showed that the anoxic form of $\mathrm{HK}$ was more sensitive to urea with $\mathrm{I}_{50}$ values that were significantly lower for the hepatopancreas (by 14\%) and foot muscle (by 18\%) enzyme as compared with the corresponding control value (Table 3.1; Table 3.2).

\section{Salts effects on HK activity}

The effects of increasing $\mathrm{NaCl}, \mathrm{KCl}$ and $\mathrm{NH}_{4} \mathrm{Cl}$ concentrations on enzyme activity was also investigated and it was observed that ionic effects on hepatopancreas HK were the same for both the control and anoxic enzyme. I $_{50}$ values for the three salts tested ranged between $0.23-0.29 \mathrm{M}$ and were not significantly different between the two states (Table 3.1). Likewise for HK from foot muscle, control and anoxic snails reacted to increasing ion concentrations in the same way. $\mathrm{I}_{50}$ values ranged from $0.19-0.30 \mathrm{M}$ for HK from both control and anoxic snails (Table 3.2). 


\section{In vitro incubations to assess the phosphorylation state of $\mathrm{HK}$}

Aliquots of crude extracts of hepatopancreas from control and anoxic snails were incubated for $4 \mathrm{~h}$ at $4^{\circ} \mathrm{C}$ under conditions that stimulated the activities of endogenous protein kinases or phosphatases and the effects on glucose substrate affinity $\left(\mathrm{K}_{\mathrm{m}}\right)$ were determined (Figure 3.2). Incubations under conditions that stimulated PKG, PKC or AMPK resulted in significant increases in the $\mathrm{K}_{\mathrm{m}}$ glucose of the anoxic form of $\mathrm{HK}$ to values that were similar to the control form (Fig. 3.2a). For example, under incubation conditions that stimulated AMPK activity, the anoxic $\mathrm{K}_{\mathrm{m}}$ glucose increased by $40 \%$ as compared to the STOP condition. Stimulation of other kinases failed to alter $\mathrm{K}_{\mathrm{m}}$ glucose for HK from anoxic snails, and no kinase treatment affected HK from control snails.

Conversely, Figure $3.2 \mathrm{~b}$ shows that incubations which stimulated specific protein phosphatases reduced $\mathrm{K}_{\mathrm{m}}$ glucose values in preparations from control snails but did not affect HK in extracts from anoxic snails. Stimulation of several phosphatase classes (PP1+PP2A-type activity, PP2B-type activity, and total serine/threonine phosphatases) significantly reduced the $\mathrm{K}_{\mathrm{m}}$ glucose of control $\mathrm{HK}$ to values similar to the anoxic form. For example, incubations stimulating Total Ser/Thr phosphatases decreased the control $\mathrm{K}_{\mathrm{m}}$ glucose by $33 \%$ as compared to the STOP condition.

The results of similar incubations with foot muscle HK are shown in Figure 3.3 but with $\mathrm{K}_{\mathrm{m}}$ ATP assessed in this case. Stimulation of several protein kinases (PKA, PKG, PKC and CaMK) increased the $K_{m}$ ATP of the control enzyme significantly and values rose to levels similar to those of the untreated anoxic form (Fig. 3.3a). For example, upon incubation under conditions that stimulated PKG, the $\mathrm{K}_{\mathrm{m}}$ ATP of control HK increased by $118 \%$ as compared to its STOP condition. However, $\mathrm{K}_{\mathrm{m}}$ ATP of foot 
muscle HK from anoxic snails was not affected by any of the protein kinase treatments.

By contrast, the anoxic form of HK in foot muscle was sensitive to treatments that stimulated protein phosphatases. All tested phosphatase treatments significantly decreased $\mathrm{K}_{\mathrm{m}}$ ATP of anoxic HK to values similar to the control form (Fig. 3.3b). For example, incubations stimulating Total Ser/Thr phosphatases decreased the $K_{m}$ ATP of anoxic $\mathrm{HK}$ by $51 \%$ as compared to anoxic HK under STOP conditions. None of the phosphatase treatments had any effect on foot muscle HK from control snails.

Table 3.3 presents a summary of the incubation studies indicating which protein kinases and phosphatases were responsible for the phosphorylation and dephosphorylation of $\mathrm{HK}$ in hepatopancreas and foot muscle tissues.

\section{Immunoprecipitation of Radiolabelled Phosphorylated HK}

To confirm that the above incubations actually did transfer phosphate groups onto $\mathrm{HK}$, the protein kinase incubations were run again in the presence of $\gamma^{32} \mathrm{P}$-ATP. Then, ${ }^{32} \mathrm{P}$-labelled HK was immunoprecipitated using a HK antibody and insoluble protein A. Figure 3.4 shows the relative intensity of the radioactive spots on P81 paper. HK in hepatopancreas and foot muscle extracts from control snails was first dephosphorylated by incubating under Total Phosphatase conditions and then incubated with $\gamma-{ }^{32} \mathrm{P}-\mathrm{ATP}$ under two conditions: STOP conditions that inhibited both kinases and phosphatases and Total Kinase conditions that promoted the activity of all protein kinases. The results show that there was a significant increase in ${ }^{32} \mathrm{P}$-labelled HK under Total Kinase incubation conditions as compared with the respective STOP conditions. For control extracts from hepatopancreas and foot muscle, there was a 2.21 -fold and 3.60-fold increase, 
respectively, in ${ }^{32} \mathrm{P}$ incorporation under Total Kinase incubation conditions compared to their respective STOP conditions.

\section{Ion exchange chromatography of high and low phosphate forms of $\mathrm{HK}$}

DEAE-Sephadex chromatography resolved two peaks of HK activity from crude hepatopancreas extracts, one peak in control and one in anoxic snails (Fig. 3.5). Peak I present in the anoxic hepatopancreas eluted at approximately $0.6 \mathrm{M} \mathrm{KCl}$, whereas Peak II present in the control hepatopancreas eluted at a higher value of $1.0 \mathrm{M} \mathrm{KCl}$.

Likewise, DEAE-Sephadex chromatography resolved two peaks of HK activity from crude foot muscle extracts of both control and anoxic snails (Fig. 3.6). For foot muscle studies, extracts from both control and anoxic snails were combined and run simultaneously. Peaks I and II eluted at approximately $0.8 \mathrm{M}$ and $1.0 \mathrm{M} \mathrm{KCl}$, respectively. 
Table 3.1. Kinetic parameters for hexokinase from hepatopancreas of control and $24 \mathrm{~h}$ anoxic $L$. littorea.

\begin{tabular}{|c|c|c|}
\hline & Control & $24 \mathrm{~h}$ Anoxic \\
\hline $\mathrm{K}_{\mathrm{m}}$ Glucose $(\mathrm{mM})$ & $0.091 \pm 0.007$ & $0.059 \pm 0.003^{*}$ \\
\hline $\mathrm{K}_{\mathrm{m}} \mathrm{ATP}(\mathrm{mM})$ & $0.16 \pm 0.02$ & $0.14 \pm 0.01$ \\
\hline $\mathrm{V}_{\max }(\mathrm{mU} / \mathrm{mg}$ soluble protein) & $3.3 \pm 0.2$ & $1.7 \pm 0.1^{*}$ \\
\hline $\mathrm{I}_{50}$ Urea $(\mathrm{M})$ & $1.49 \pm 0.04$ & $1.31 \pm 0.03^{*}$ \\
\hline $\mathrm{I}_{50} \mathrm{NaCl}(\mathrm{M})$ & $0.24 \pm 0.02$ & $0.29 \pm 0.01$ \\
\hline $\mathrm{I}_{50} \mathrm{KCl}(\mathrm{M})$ & $0.26 \pm 0.02$ & $0.260 \pm 0.002$ \\
\hline $\mathrm{I}_{50} \mathrm{NH} 4 \mathrm{Cl}(\mathrm{M})$ & $0.23 \pm 0.02$ & $0.23 \pm 0.01$ \\
\hline
\end{tabular}

Assays were performed at $22^{\circ} \mathrm{C}$ and data are means $\pm \mathrm{SEM}, \mathrm{n}=4$ preparations from different animals. Kinetic constants were determined at optimal concentrations of ions or cosubstrates. * - Significantly different from the control value using the Student's t-test, $p<0.05$. 
Table 3.2. The kinetic parameters of foot muscle hexokinase from control and $24 \mathrm{~h}$ anoxic L. littorea.

\begin{tabular}{|c|c|c|}
\hline & Control & 24 h Anoxia \\
\hline $\mathrm{K}_{\mathrm{m}}$ Glucose $(\mathrm{mM})$ & $0.15 \pm 0.05$ & $0.15 \pm 0.02$ \\
\hline $\mathrm{K}_{\mathrm{m}} \mathrm{ATP}(\mathrm{mM})$ & $0.24 \pm 0.01$ & $0.55 \pm 0.04^{*}$ \\
\hline $\mathrm{V}_{\max }(\mathrm{mU} / \mathrm{mg}$ soluble protein) & $6.0 \pm 0.5$ & $3.7 \pm 0.4^{*}$ \\
\hline $\mathrm{I}_{50}$ Urea (M) & $1.17 \pm 0.06$ & $0.99 \pm 0.06^{*}$ \\
\hline $\mathrm{I}_{50} \mathrm{NaCl}(\mathrm{M})$ & $0.28 \pm 0.01$ & $0.30 \pm 0.01$ \\
\hline $\mathrm{I}_{50} \mathrm{KCl}(\mathrm{M})$ & $0.28 \pm 0.02$ & $0.28 \pm 0.01$ \\
\hline $\mathrm{I}_{50} \mathrm{NH}_{4} \mathrm{Cl}(\mathrm{M})$ & $0.210 \pm 0.007$ & $0.19 \pm 0.01$ \\
\hline
\end{tabular}

Assays were performed at $22^{\circ} \mathrm{C}$ and data are means $\pm S E M, n=4$ preparations from different animals. Kinetic constants were determined at optimal concentrations of ions or cosubstrates. * - Significantly different from the control value using the Student's t-test, $p<0.05$ 
Table 3.3. Summary of the incubation studies to investigate the regulation of hexokinase under control and anoxic conditions of the L. littorea.

\begin{tabular}{|c|c|c|c|c|}
\hline Tissue & $\begin{array}{c}\text { Critical } \\
\text { Protein } \\
\text { Kinases }\end{array}$ & Effect & $\begin{array}{c}\text { Critical } \\
\text { Protein } \\
\text { Phosphatases }\end{array}$ & Effect \\
\hline Hepatopancreas & PKG, & Increase Anoxic & PP1+PP2A, & PP2B, \\
& AMPK & $\mathrm{K}_{\mathrm{m}}$ Glucose & Tot Ser/Thr & $\mathrm{K}_{\mathrm{m}}$ Glucose \\
& PKA, & & PP1, & \\
& PKG, & Increase Control & PP1+PP2A, & Decrease Anoxic \\
& PKC, & $\mathrm{K}_{\mathrm{m}}$ ATP & PP2B, PP2C, & $\mathrm{K}_{\mathrm{m}}$ ATP \\
& CaMK & & Tot Ser/Thr & \\
\hline
\end{tabular}


Figure 3.1. Determination of optimal $\mathrm{pH}$ for hexokinase activity from hepatopancreas of control and anoxic L. littorea. Optimal assay conditions were used at $22^{\circ} \mathrm{C}$ with $50 \mathrm{mM}$ Imidazole assay buffer for $\mathrm{pH}$ 6.0-7.5, $50 \mathrm{mM}$ Tricine buffer for $\mathrm{pH} 8.0-8.5$, and $50 \mathrm{mM}$ CHES buffer for $\mathrm{pH}$ 9.0. Data are means \pm SEM, $n=4$ trials on independent preparations of enzyme. 
Figure 3.1

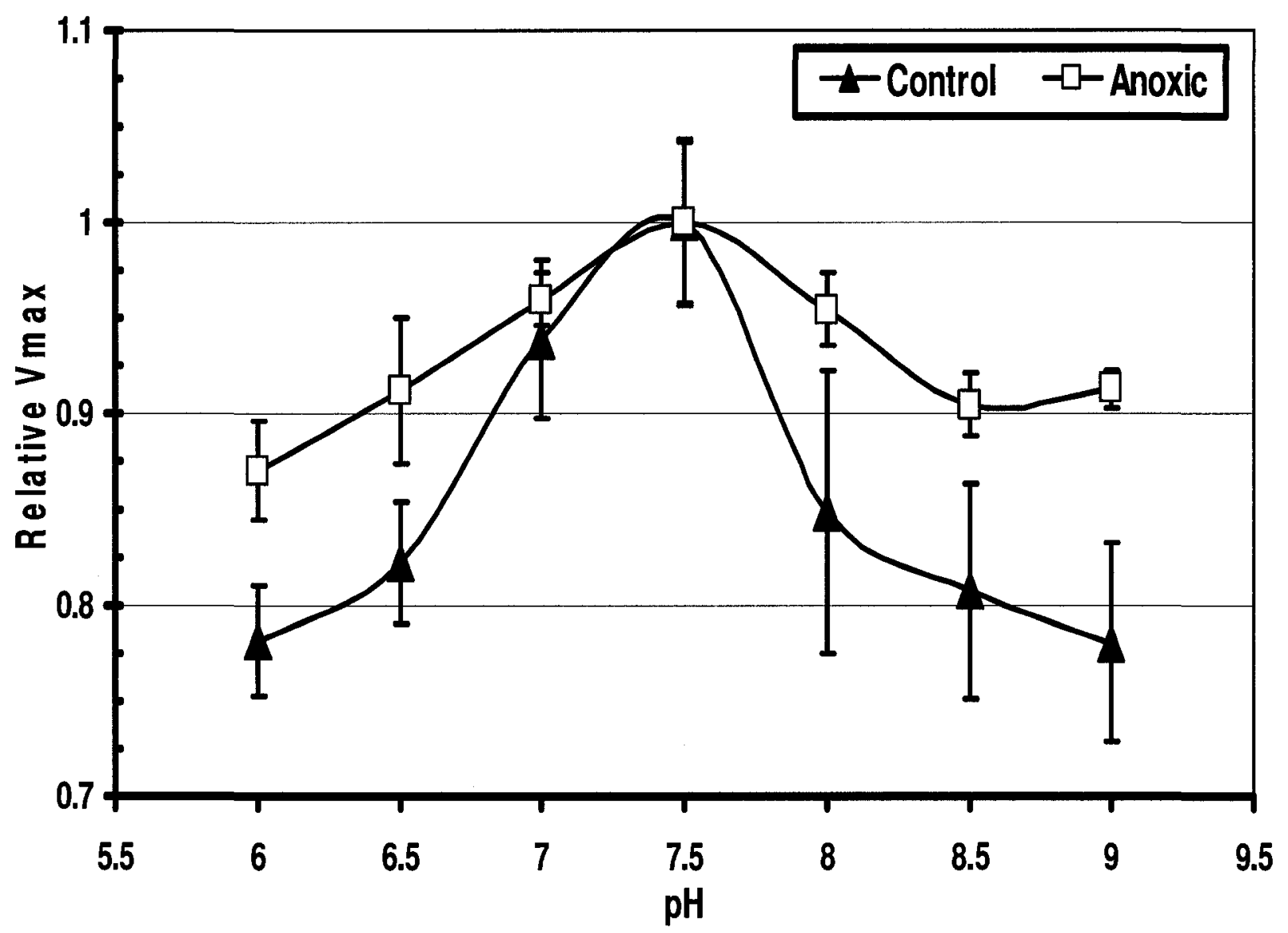


Figure 3.2. Effects of in vitro incubations to stimulate the activities of (A) protein kinases or (B) protein phosphatases on the $\mathrm{K}_{\mathrm{m}}$ glucose of hepatopancreas $\mathrm{HK}$ from aerobic control and $24 \mathrm{~h}$ anoxic $L$. littorea. Crude extracts were incubated for $4 \mathrm{~h}$ at $4^{\circ} \mathrm{C}$ before assay at room temperature. Data are means $\pm S E M, n=3$ trials on independent preparations of enzyme from different animals. $a$ - Significantly different from the corresponding STOP value using the Dunnett's test, $P<0.05$. $b$ - Significantly different from the corresponding control value using the Dunnett's test, $P<0.05$. 
Figure 3.2

A

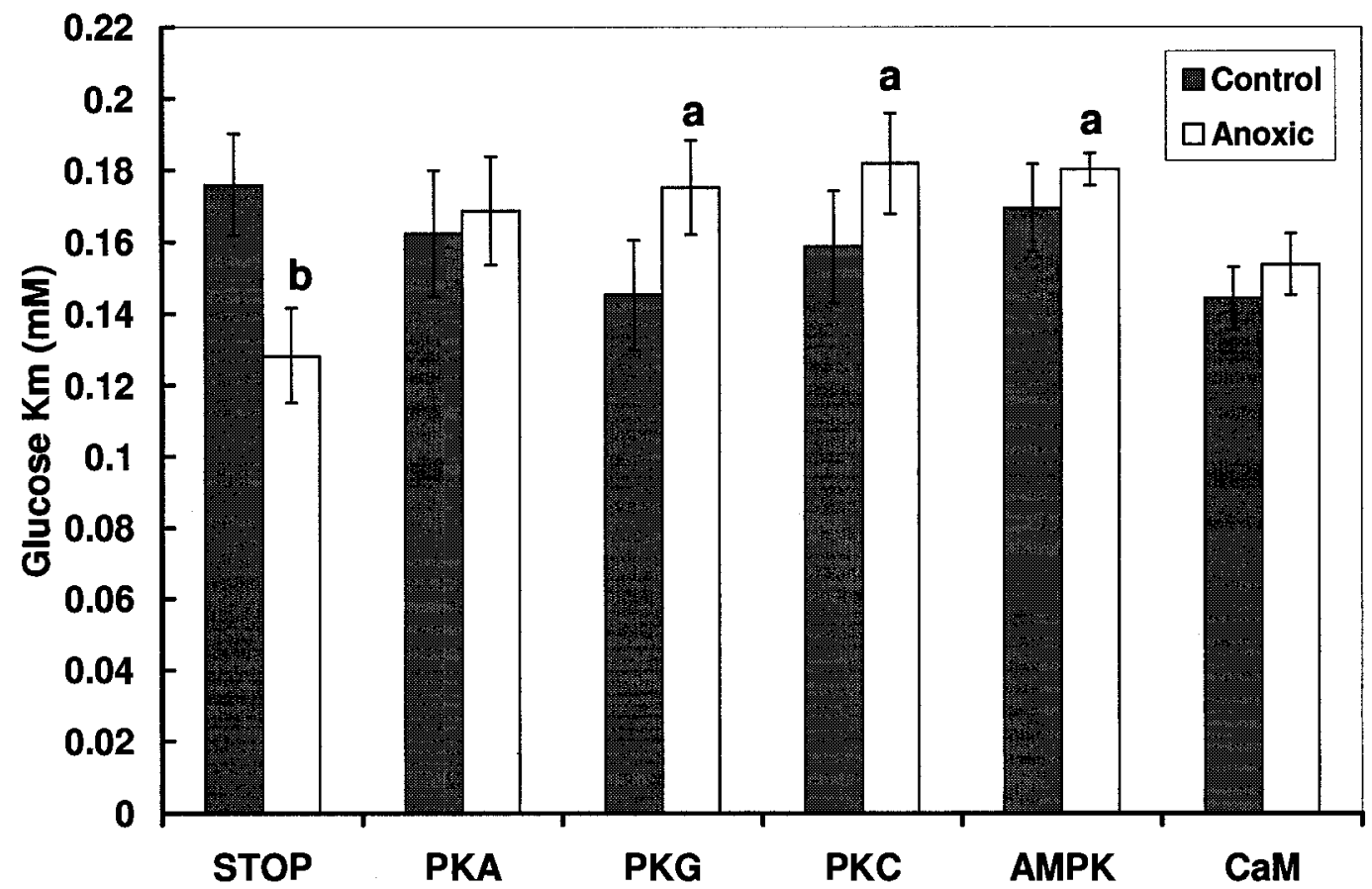

B

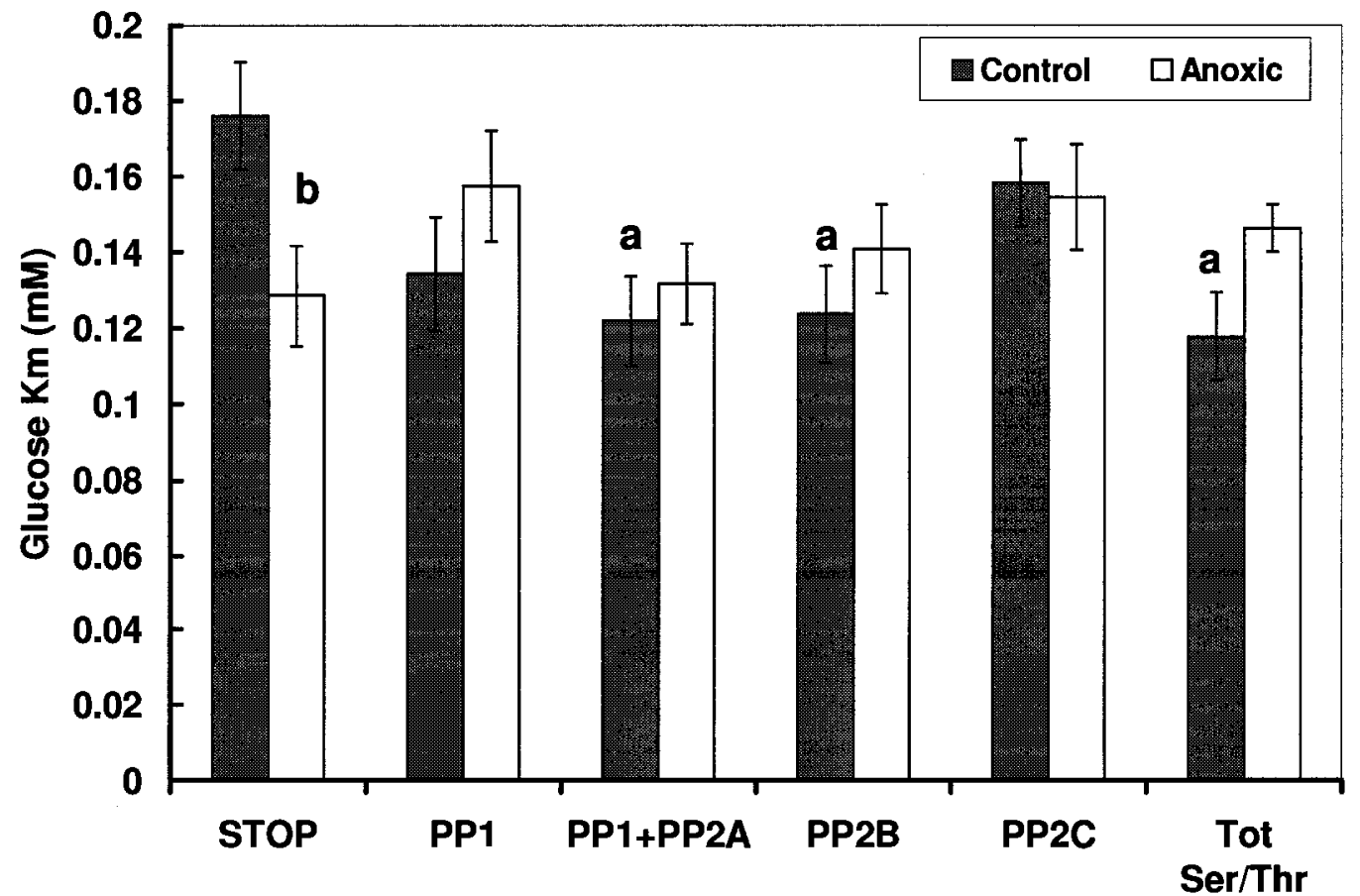


Figure 3.3. Effects of in vitro incubations to stimulate the activities of (A) protein kinases or (B) protein phosphatases on the $\mathrm{K}_{\mathrm{m}}$ ATP of foot muscle HK from aerobic control and $24 \mathrm{~h}$ anoxic $L$. littorea. Crude extracts were incubated for $4 \mathrm{~h}$ at $4^{\circ} \mathrm{C}$ before assay at room temperature. Data are means $\pm S E M, n=3$ trials on independent preparations of enzyme. $a$ - Significantly different from the corresponding STOP value using the Dunnett's test, $P<0.05$. $b$ - Significantly different from the corresponding control value using the Dunnett's test, $P<0.05$. 
Figure 3.3

A

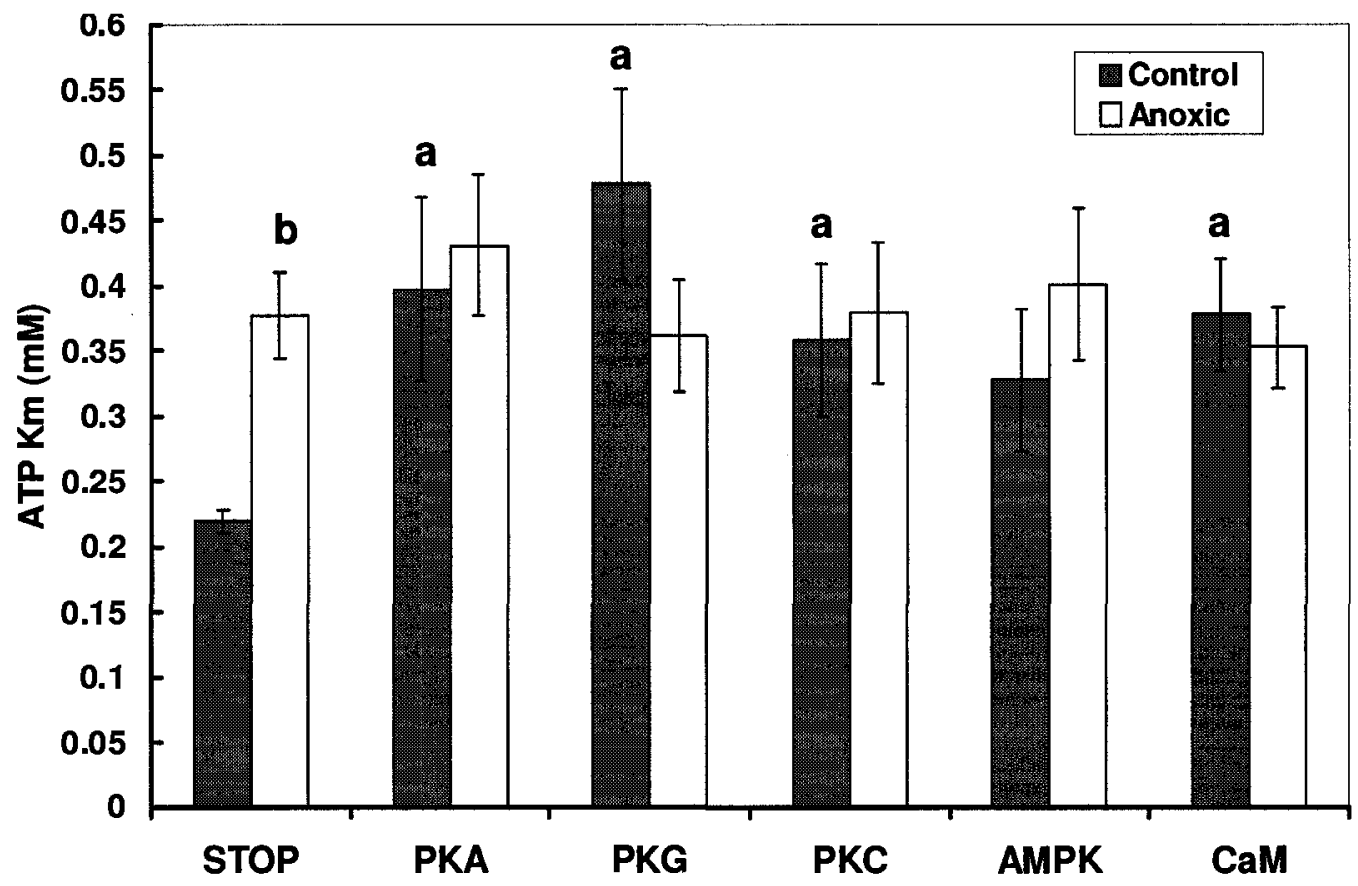

B

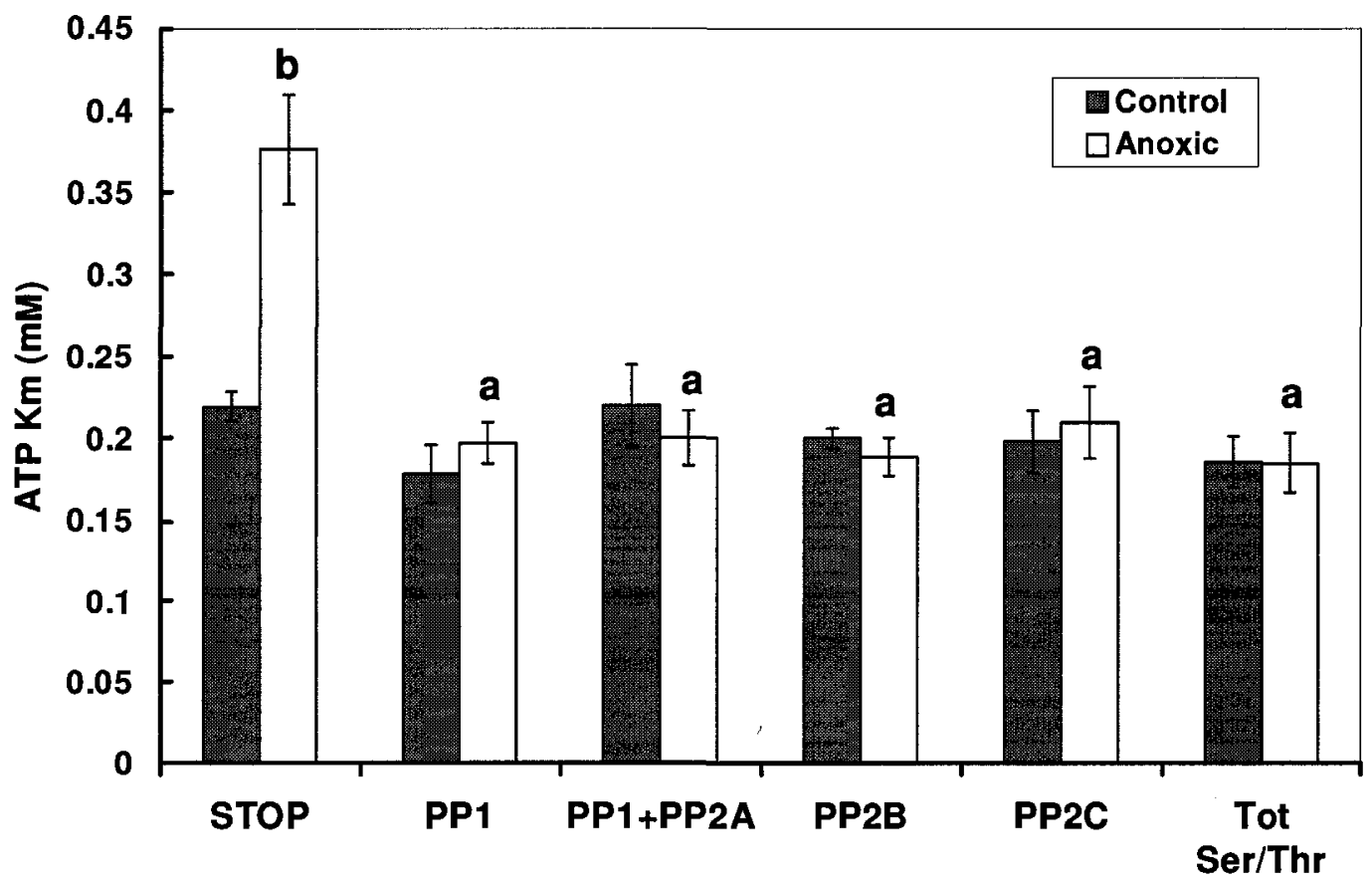


Figure 3.4. Results of the radioactive immunoprecipitation of HK from (A) control hepatopancreas and (B) control foot muscle of L. littorea. Relative intensities of ${ }^{32} \mathrm{P}$ incorporation into the immunoprecipitate is compared under conditions that stimulated the activities of all protein kinases (Total Kinase) versus conditions that inhibited all kinases and phosphatases (STOP); conditions for both are defined in the Materials and Methods. Data are means \pm SEM, $n=3$ determinations on separate preparations of enzyme. $a$ - Significantly different from the corresponding STOP value using Student's t-test, $P<0.05$. 
Figure 3.4

A

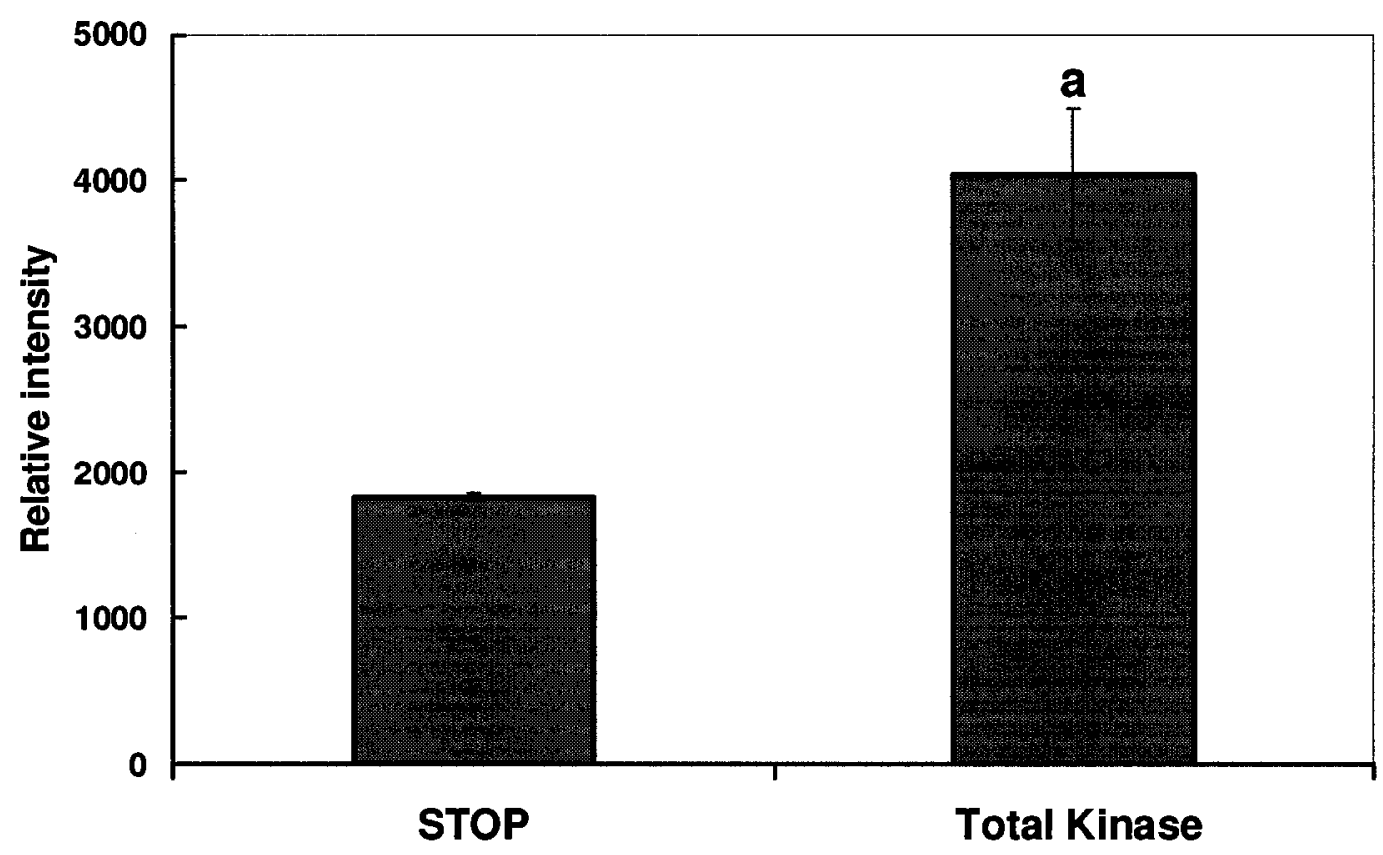

B

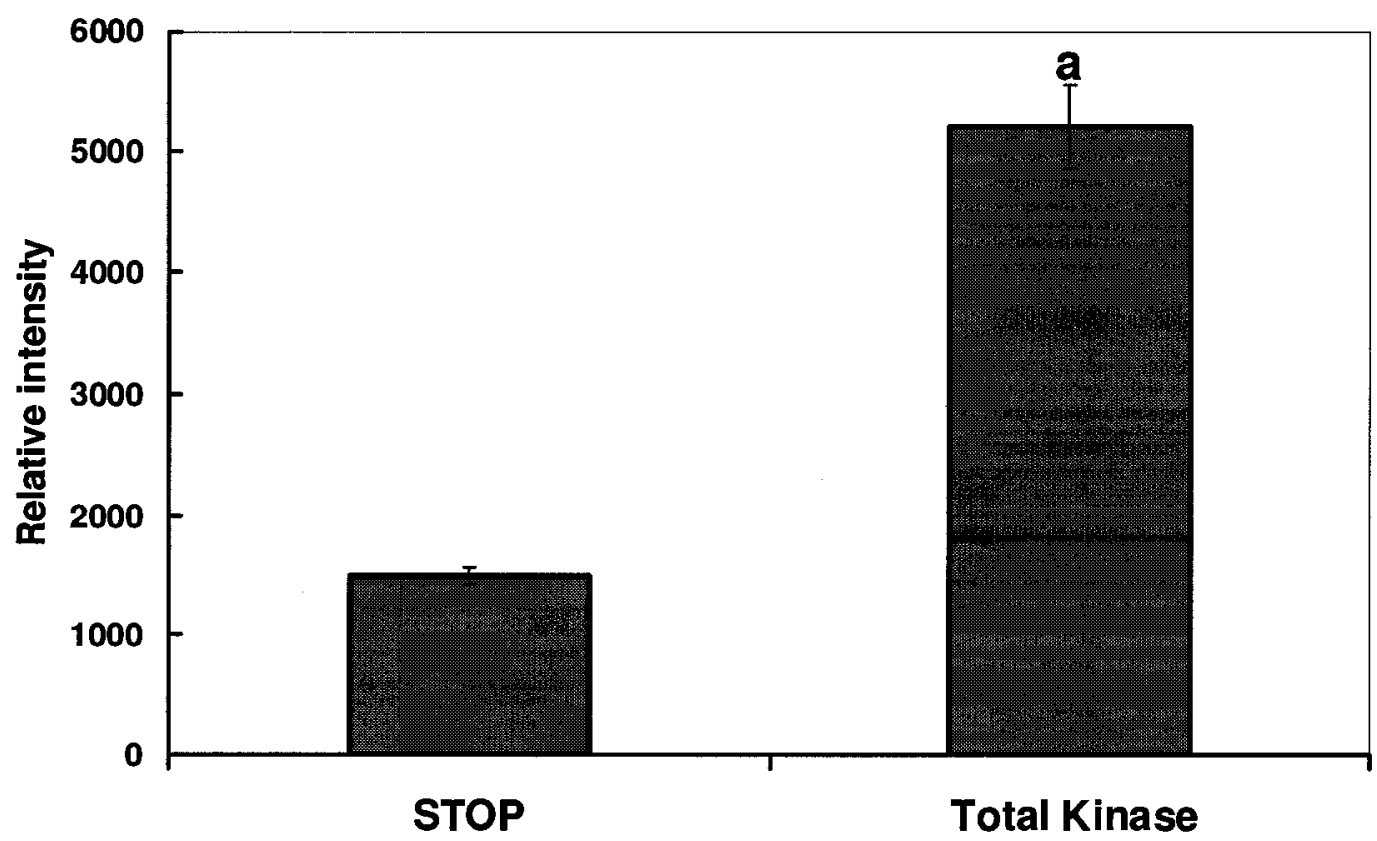


Figure 3.5. DEAE-Sephadex elution profiles for HK activity from hepatopancreas of control and $24 \mathrm{~h}$ anoxic $L$. littorea. Profiles are representative of three independent determinations for each condition. Activities are expressed relative to the highest activity fraction. Peaks I and II eluted at increasingly higher $\mathrm{KCl}$ concentrations respectively, within a $0-2.0 \mathrm{M} \mathrm{KCl}$ salt gradient, $\mathrm{pH}$ 7.0. 
Figure 3.5

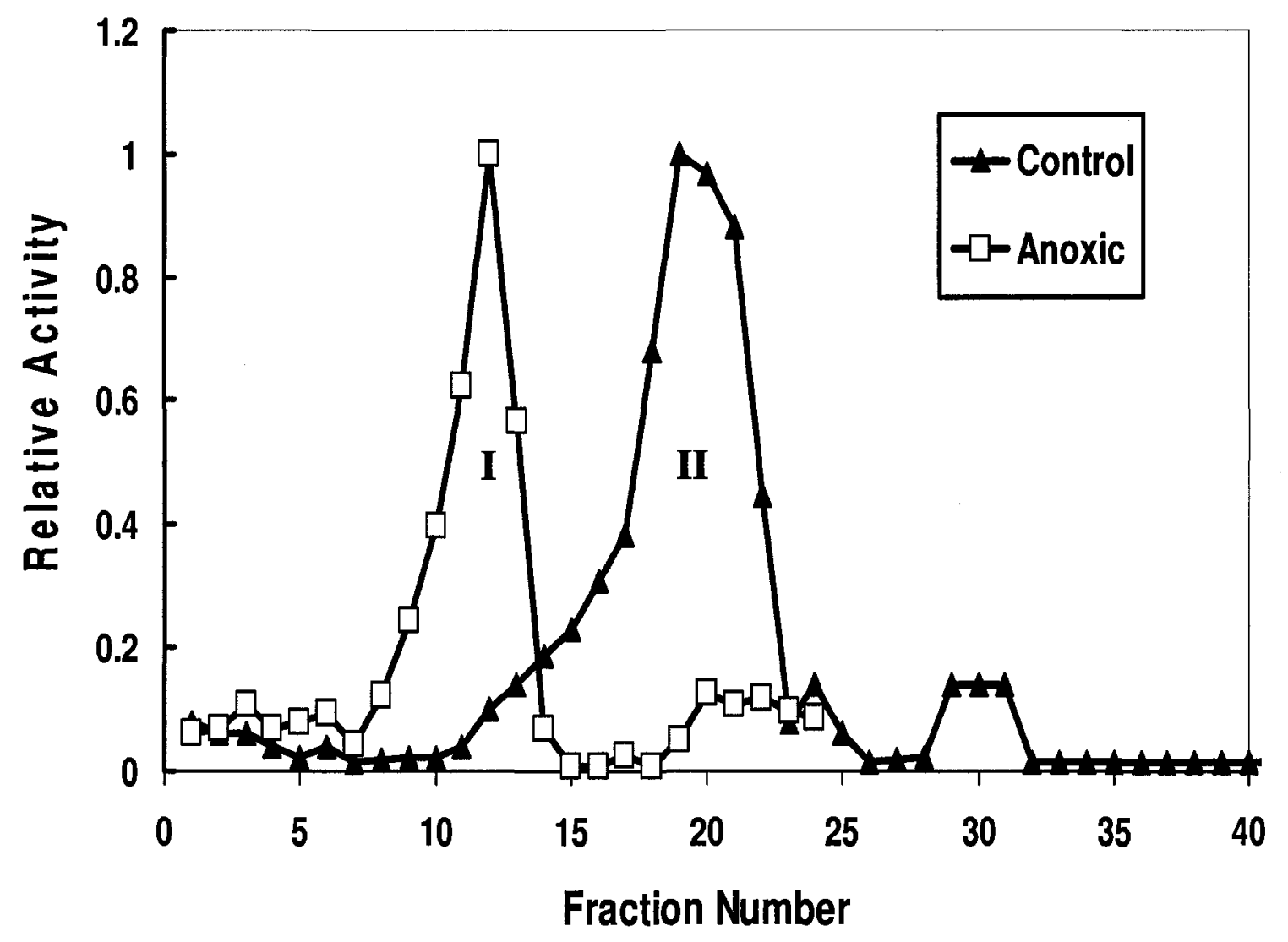


Figure 3.6. DEAE-Sephadex elution profiles for HK activity from foot muscle of control and $24 \mathrm{~h}$ anoxic $L$. littorea. Extracts of control and anoxic muscle were combined and run simultaneously. The profile is representative of three independent determinations for each condition. Activities are expressed in $\mathrm{mU}$ of activity. Peaks I and II eluted at increasingly higher $\mathrm{KCl}$ concentrations respectively, within a $0-2.0 \mathrm{M} \mathrm{KCl}$ salt gradient, $\mathrm{pH}$ 7.0. 
Figure 3.6

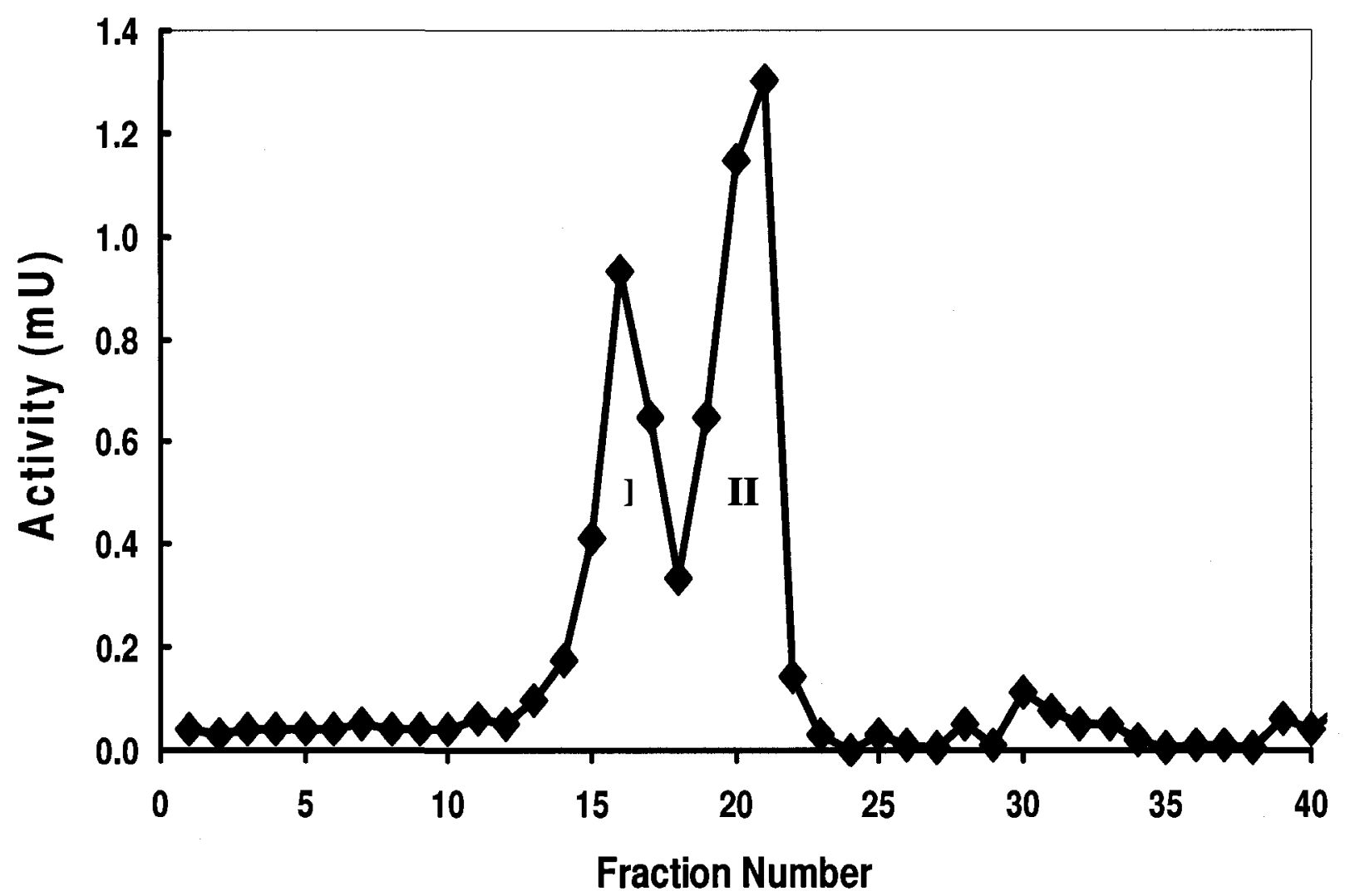


Figure 3.7. Representative figure showing possible native phosphorylation states of HK in the (A) hepatopancreas and (B) foot muscle of $L$. littorea, based on the results from the in vitro protein kinase and phosphatase incubations. 
Figure 3.7

A

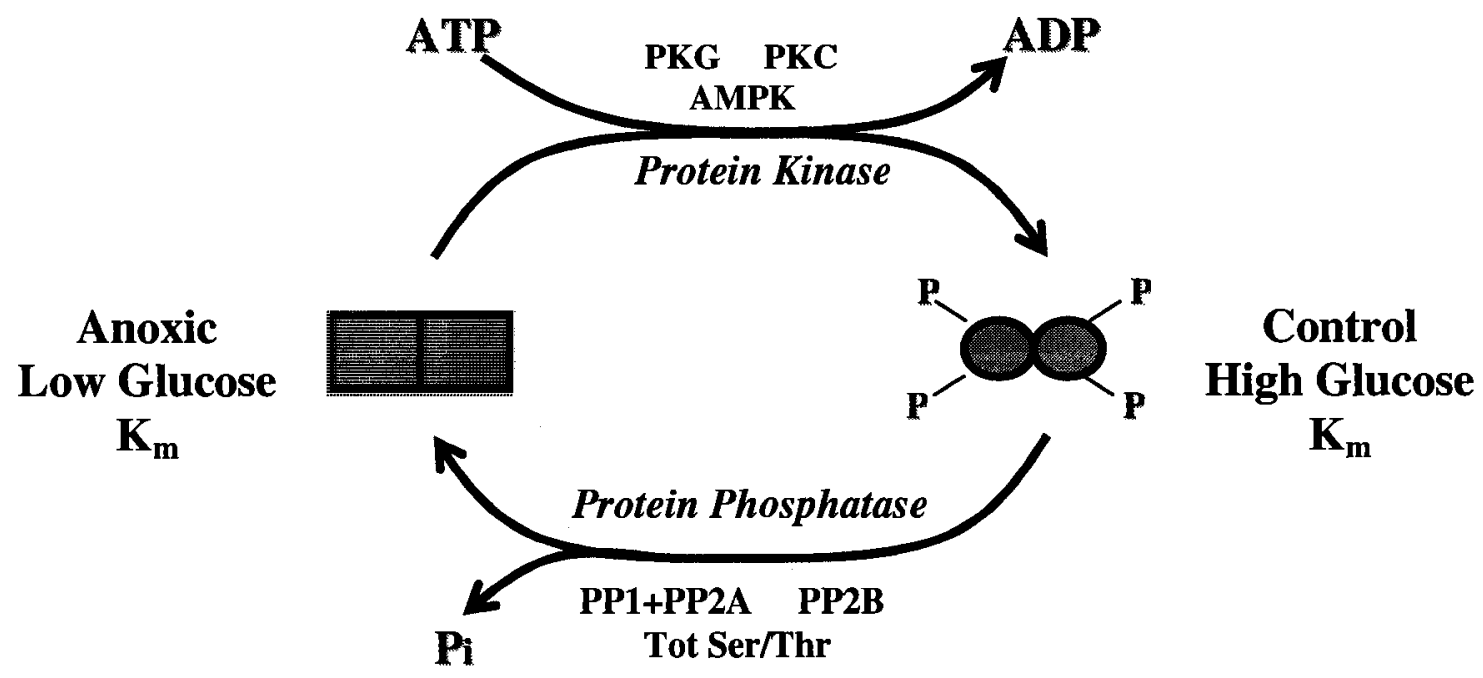

B

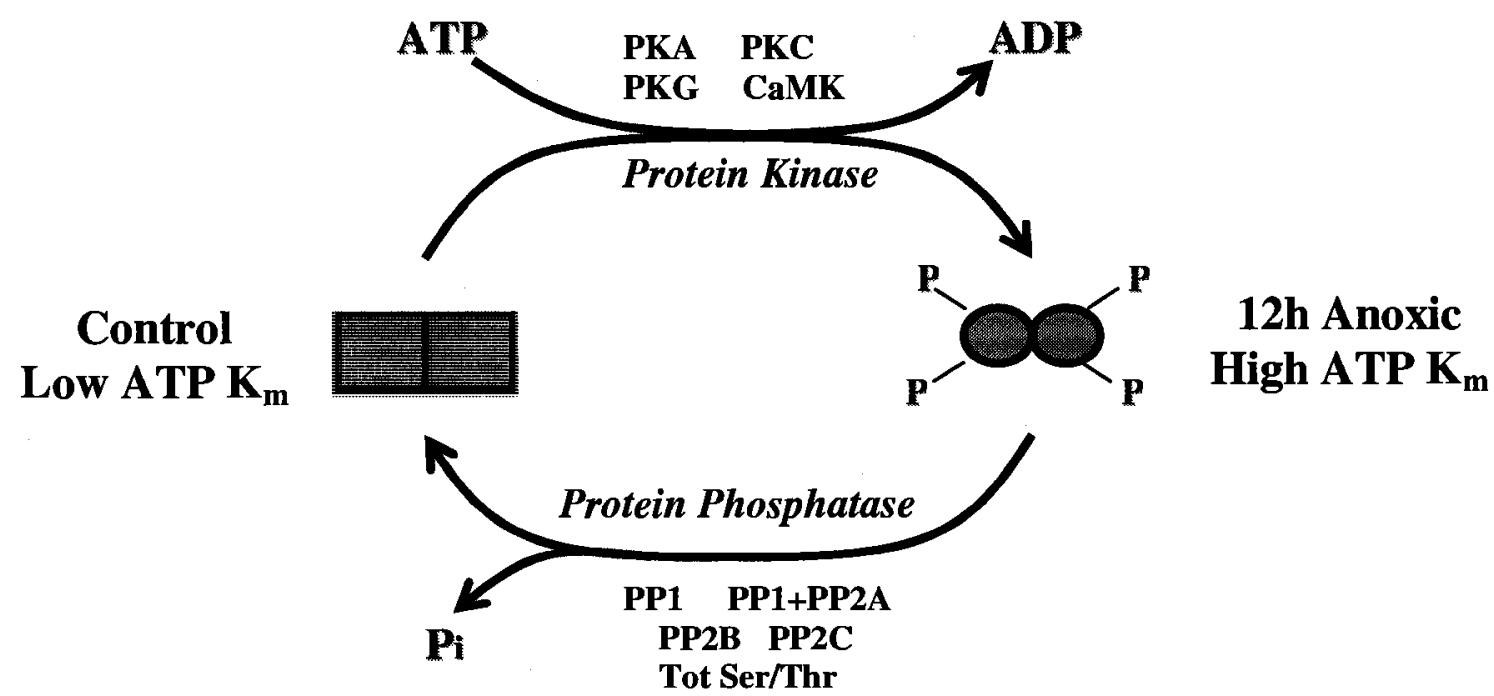




\section{Discussion}

Hexokinase from both the hepatopancreas and foot muscle tissues of the marine mollusc, $L$. littorea is subject to reversible phosphorylation and the data indicate that this mechanism underlies the anoxia-induced changes in activity and kinetic properties of the enzyme. It also appears that HK is regulated in a tissue-specific manner, with HK during anoxia being enhanced versus suppressed in the hepatopancreas and foot muscle, respectively. This is one of the first examples in which phosphorylation control of hexokinase has been implicated as a component of metabolic rate depression in an animal system undergoing the environmental stress of anoxia.

Analysis of various kinetic parameters revealed significant anoxia-induced changes in both hepatopancreas and foot muscle HK. However, neither tissue appeared to have any detectable enzyme activity in the pellet, indicating that HK was a soluble enzyme, which agrees with data from other invertebrate HKs such as the locust (Kerley and Leaback, 1957; Vaughan et al, 1973; Storey, 1980). In the hepatopancreas, the anoxic form of $\mathrm{HK}$ was the overall more active enzyme at acidic $\mathrm{pH}$ conditions as indicated by its higher maximal velocity at lower $\mathrm{pH}$ environments (Fig. 3.1). As previously mentioned in Chapter 2 , having a more active enzyme under acidic $\mathrm{pH}$ conditions is beneficial to the snail experiencing anoxia because as anaerobic fermentation progresses and acidic end-products build up, the intracellular $\mathrm{pH}$ decreases (Ellington 1983; Ellington, 1983; Pörtner et al., 1984; Walsh et al., 1984; Russell and Storey, 1995). The anoxic form of HK from the hepatopancreas also had a lower $\mathrm{K}_{\mathrm{m}}$ for glucose than the control version as well as a reduced maximal velocity (Table 3.1 ). The regulation of HK during anoxia may result in a decrease of its maximal velocity which 
facilitates overall metabolic rate depression and suppresses overall glucose utilization in marine molluscs (Storey and Storey, 2004b). The decrease in the $K_{m}$ glucose of hepatopancreas HK in anoxia would facilitate the phosphorylation of glucose and provide G6P to pathways that need this substrate during anoxia. The increase in substrate affinity could help HK since under anoxic conditions, aerobic respiration completely shuts down and animals must rely on anaerobic fermentative pathways for energy (Storey and Storey, 2004a). Under normal aerobic conditions, the liver and liver-like organs (hepatopancreas) primarily use fatty acids as substrates for oxidation, and the glycolytic rate is extremely suppressed (Seifter and Englard, 1994; Stryrer, 1995; Stuart and Ballantyne, 1997). However when the hepatopancreas is rendered anoxic, production of ATP by oxidative phosphorylation shuts down and the glycolytic rate is greatly increased. Although glycogen is the primary carbohydrate fuel, HK must still continue to scavenge glucose and all other available hexoses to meet energetic demands (Seifter and Englard, 1994). Also, since G6PDH and the PPP are enhanced in the hepatopancreas under anoxia (see Chapter 2), it could be reasoned that a coordinated enhancement of hepatopancreas HK in anoxia is important for the provision of substrate to both the glycolytic and the pentose phosphate pathways.

In foot muscle, HK kinetic parameters changed differently in anoxia as compared with hepatopancreas tissue. The anoxic form of $\mathrm{HK}$ from foot muscle had a higher $\mathrm{K}_{\mathrm{m}}$ for ATP and lower maximal velocity than the control version (Table 3.2). These changes in HK kinetic parameters from foot muscle control and anoxic states would reduce HK activity and are consistent with a general decrease in metabolic rate experienced by marine snails under anoxia (Storey and Storey, 2004a). Also during anoxia, the snail 
attempts to conserve as much energy as possible and therefore would not be using its foot muscle for unnecessary locomotion as it may do under normoxia.

Hexokinase from both the hepatopancreas and foot muscle tissue of $L$. littorea reacted in a similar fashion to urea-dependent denaturation. In both tissues, the anoxic form of HK was more susceptible to urea denaturation than the control form, as indicated by its significantly lower $I_{50}$ urea (Table 3.1, 3.2). The difference in HK stability to urea denaturation may derive from small differences in protein structure between control and stress states. As explained in the previous chapter, the urea susceptibility of the stress form of an enzyme may suggest an inherently greater flexibility in protein structure which is more beneficial to the enzyme undergoing a variety of environmental stress conditions (Abnous and Storey, 2007). Therefore, since the intertidal snail encounters many environmental stresses such as anoxia, acidosis, freezing and varying salt and toxin levels, the greater flexibility of the stress form of $\mathrm{HK}$ would aid the enzyme in maintaining its function in an ever-changing cellular environment (Abnous and Storey, 2008).

HK from both tissues was relatively insensitive to high ion concentrations since $I_{50}$ values for chloride salts were in the range of $190-300 \mathrm{mM}$ and did not change between control and anoxic states. A relative insensitivity to high ion concentrations by enzymes in L. littorea is likely adaptive for this intertidal inhabitant. The body fluids of marine invertebrates are isosmotic with seawater and intertidal species can experience wide variations in environmental salinity that consequently changes their body fluid osmolarity. Although total body fluid osmolarity may change, inorganic ions such as $\mathrm{K}^{+}$, $\mathrm{Na}^{+}$and $\mathrm{Cl}^{-}$are strongly conserved in their concentrations among species that are 
acclimated to different osmotic strengths (Schoffeniels, 1976; Yancey et al., 1982). It is also worth noting that although the total osmolarity of intracellular fluids in marine invertebrates is high, it is only partly composed of ions; with the remainder of the osmotic strength attributed to a high free amino acid content (Berger and Kharazova, 1997; Plaut, 1999). In fact, amino acids contribute up to about $50 \%$ of the intracellular osmotic pressure of aquatic invertebrates (Schoffeniels, 1976). Therefore, it is the extracellular environment in L. littorea which may experience an increase in salinity, whereas the intracellular environment maintains a moderately low salt concentration in conjunction with a high amino acid concentration (Shumway, 1977).

Given that there were significant differences in some of the kinetic properties of both hepatopancreas and foot muscle HK between control and anoxic states, I investigated the possibility that these kinetic differences were due to covalent modification of the enzyme, specifically to reversible protein phosphorylation. For HK in the hepatopancreas, in vitro incubations that stimulated the activities of three endogenous protein kinases (PKG, PKC, AMPK) all inhibited $\mathrm{HK}$ in anoxic extracts by increasing its $\mathrm{K}_{\mathrm{m}}$ glucose to levels similar to those seen in control tissue (Fig. 3.2a). Similar findings have been reported in the skeletal muscle of the hibernating ground squirrel, Spermophilus richardsonii, where AMPK was also implicated in phosphorylation control of HK (Abnous and Storey, 2008). Previous studies have shown that AMPK also triggers strong transcriptional up-regulation of hexokinase in mammalian skeletal muscle and the data indicates that AMPK, along with the above stated protein kinases, has an additional role in the direct phosphorylation of HK to change its kinetic properties (Holmes et al., 1999; Stoppani et al., 2002). Also, phosphorylation of HK has been found in yeast, $S$. 
cerevisiae although its mechanism was not further investigated (Vojtek and Fraenkel, 1990; Randez-Gil et al., 1998). Therefore, it is possible that one or more of these protein kinases could mediate the recovery to normoxia, in vivo, of hepatopancreatic $\mathrm{HK}$.

Oppositely, in vitro incubations that stimulated selected endogenous protein phosphatases (PP1+PP2A, PP2B, or total serine/threonine phosphatases) significantly decreased the $K_{m}$ glucose of the control enzyme to values characteristic of the anoxic version (Fig. 3.2b). HK has also been shown to undergo dephosphorylation in the skeletal muscle of hibernating ground squirrels in response to stimulation of both PP1-type and PP2B-type phosphatases (Abnous and Storey, 2008). Additionally in yeast, the role of hexokinase in the glucose response is mediated by reversible phosphorylation; and more specifically, PP1-type phosphatases have been shown to dephosphorylate HK (RandezGil et al., 1998; Alms et al., 1999). Therefore, these specific phosphatases may be the endogenous phosphatases responsible for controlling hepatopancreatic $\mathrm{HK}$ dephosphorylation upon entry of $L$. littorea into anoxia.

Taking the kinase and phosphatase incubations into consideration, one may hypothesize that $\mathrm{HK}$ in aerobic, control hepatopancreas is the high-phosphate enzyme form whereas the anoxic enzyme is the low-phosphate form. Figure 3.7a displays a representative figure of possible native phosphorylation states of $\mathrm{HK}$ from both control and anoxic hepatopancreas tissue, based on the results from the in vitro protein kinase and phosphatase incubations. I suggest the transition between the control and anoxic forms of HK in the hepatopancreas is regulated by reversible phosphorylation. The highphosphate, high $\mathrm{K}_{\mathrm{m}}$ glucose form of hepatopancreas $\mathrm{HK}$ under aerobic conditions is dephosphorylated by specific phosphatases (PP1+PP2A, PP2B or total serine/threonine 
phosphatases) to make it more like the low-phosphate, low $\mathrm{K}_{\mathrm{m}}$ glucose anoxic version. Likewise, treatment of the low-phosphate anoxic form of hepatopancreas HK with PKG, $\mathrm{PKC}$, or AMPK increased the phosphorylation state of the anoxic enzyme, which in turn increased its $\mathrm{K}_{\mathrm{m}}$ glucose, making it similar to the high-phosphate, control version (Fig. 3.7a).

These same protein kinase and phosphatase incubations were performed on foot muscle extracts to see if they had an effect on the $\mathrm{K}_{\mathrm{m}}$ ATP of muscle HK. It was observed that phosphorylation of the control aerobic form by PKA, PKG, PKC, or CaMK inhibited the enzyme by increasing the $\mathrm{K}_{\mathrm{m}}$ ATP to values similar to those seen in anoxia (Fig. 3.3a). As mentioned earlier, HK has been shown to be phosphorylated in a variety of animals from yeast to mammals (Vojtek and Fraenkel, 1990; Randez-Gil et al., 1998; Abnous and Storey, 2008). Furthermore, in the anoxia-tolerant sea mussel M. edulis, PKA and PKC were also implicated in the phosphorylation control of another key glycolytic enzyme, pyruvate kinase (Holwerda et al., 1983; Holwerda et al., 1989). Therefore, these results indicate that any one, or combination, of the above mentioned kinases may be responsible for the phosphorylation of foot muscle $\mathrm{HK}$ in vivo during entry into anoxia.

Conversely, incubations that stimulated specific protein phosphatases had the opposite effect on the $K_{m}$ ATP of the anoxic enzyme, decreasing the $K_{m}$ to values similar to the aerobic control form (Fig. 3.3b). Evidence for reversible phosphorylation control of HK has been demonstrated in yeast, implicating PP1-type phosphatase activity (Alms et al., 1999). All phosphatase treatments had this effect and so it is plausible that any of these phosphatases could mediate the in vivo dephosphorylation of $\mathrm{HK}$ in foot muscle 
during recovery from anoxia to normoxia.

As with the hepatopancreas, the results of the kinase and phosphatase incubations illustrate a reversible phosphorylation control of foot muscle HK during anoxia. It appears that the anoxic form of foot muscle HK has the higher phosphorylation state compared with the control form. Figure $3.7 \mathrm{~b}$ displays a representative figure of possible native phosphorylation states of $\mathrm{HK}$ from both control and anoxic foot muscle tissue, based on the results from the in vitro protein kinase and phosphatase incubations. The high-phosphate, high $\mathrm{K}_{\mathrm{m}}$ ATP anoxic version of HK was affected by all tested phosphatases, which reduced the phosphorylation state of anoxic $\mathrm{HK}$ and in the process, decreased $K_{m}$ ATP to levels found in the low-phosphate, aerobic control version. Additionally, PKA, PKC, PKG or CaMK treatments phosphorylated the low-phosphate, control version of $\mathrm{HK}$, thereby increasing its $\mathrm{K}_{\mathrm{m}}$ ATP to values found for the highphosphate, anoxic version (Fig. 3.7b).

To confirm that the incubation experiments actually did result in the transfer of phosphate groups onto $\mathrm{HK}$, the protein kinase incubations were run again in the presence of $\gamma^{32}$ P-ATP. Radiolabelled phopsho-HK was then immunoprecipitated using a HK antibody and insoluble protein A. For both hepatopancreas and foot muscle HK, these experiments demonstrated that the control form of HK (after initial dephosphorylation) incorporated high amounts of ${ }^{32} \mathrm{P}$ when incubated under conditions that stimulated protein kinases (Total Kinase) as compared with incubations under STOP conditions (Fig. 3.4). Radioactive immunoprecipitation thus validates the in vitro incubation results and demonstrates that both hepatopancreas and foot muscle HK have the ability to be phosphorylated, which further supports the fact that $\mathrm{HK}$ is regulated by reversible protein 
phosphorylation in L. littorea.

Since phosphorylation changes the charge state on a protein, ion exchange chromatography was used to examine the elution profile of hepatopancreas HK from aerobic and anoxic tissue. The elution profiles off a DEAE-Sephadex column showed that hepatopancreas HK from both control and anoxic conditions eluted in a single, large, distinct peak of activity, but at distinctly different salt concentrations so that the elution peaks were separated by up to 6 fractions (Fig. 3.5). The anoxic form continuously eluted first, followed by the control form. Since the process of elution relies on disrupting the ionic charge holding the enzyme to the positively charged DEAE-Sephadex column, it seems apparent that the anoxic form of HK in the hepatopancreas has a more positive charge than its control counterpart since it was eluted first. The addition of phosphate functional groups adds a more negative charge to an enzyme, allowing it to become more tightly bound to the positive DEAE beads and thus requiring a stronger salt concentration to disrupt its interaction with the column. Differences in HK elution profiles between control and hypometabolic states have also been reported in the hibernating ground squirrel (Abnous and Storey, 2008). Therefore, the results of the DEAE-Sephadex elution profiles of hepatopancreas HK confirm that there are two, physically distinct enzyme forms and this further supports the findings of the incubation experiments which demonstrated that HK is regulated by reversible protein phosphorylation. The control form of HK is the high-phosphate, less active enzyme and the anoxic form is the lowphosphate, more active enzyme.

Similar to the results for hepatopancreas HK, combined foot muscle extracts from aerobic and anoxic snails also revealed two peaks of HK activity when run on the DEAE- 
Sephadex column (Fig. 3.6). Based on the chemistry of enzyme elution from ion exchange columns, it is clear that Peak I represents the more positively charged (less phosphorylated) form whereas Peak II represents the more negatively charged (more phosphorylated) form of foot muscle HK. Taking into account the results of the protein kinase and phosphatase incubation studies, it appears that Peak I would correlate with the control form (low-phosphate, high activity) of HK whereas Peak II would represent the anoxic form (high-phosphate, low activity).

The results presented in this chapter illustrate that during anoxia, hexokinase in the $L$. littorea is regulated by reversible protein phosphorylation in a tissue-specific manner. For the hepatopancreas, it appears that the affinity of HK for one of its substrates is enhanced during anoxia since its $\mathrm{K}_{\mathrm{m}}$ glucose is reduced. Differences between control and anoxic $\mathrm{HK}$ were also observed in their susceptibility to urea denaturation, response to protein kinase and protein phosphatase incubations (confirmed through radioactive immunoprecipitations) as well as their elution profiles from a DEAE-Sephadex ion exchange column.

Conversely, it was demonstrated that in the foot muscle, HK activity is suppressed during anoxia, illustrated by its increased $\mathrm{K}_{\mathrm{m}}$ ATP and decreased maximal velocity. As was also observed for hepatopancreas HK, the differences between control and anoxic foot muscle HK became more evident through their differences in urea denaturation, responses to in vitro kinase and phosphatase incubations, and elution profiles from ionexchange columns.

In summary, the data provides one of the first demonstrations of reversible phosphorylation regulation of $\mathrm{HK}$ from an invertebrate species. Furthermore, it is one of 
the first demonstrations that reversible phosphorylation of HK occurs in response to a low oxygen stress. The data also demonstrates that HK is regulated differently in response to anoxia in two different tissues, the liver-like hepatopancreas versus foot muscle of $L$. littorea. The data implicates specific protein kinases (for hepatopancreas: PKG, PKC, AMPK; for foot muscle: PKA, PKC PKG, CaMK) and protein phosphatases (for hepatopancreas: PP1+PP2A, PP2B, Tot Ser/Thr; for foot muscle: PP1, PP1+PP2A, PP2B, PP2C, Tot Ser/Thr) as responsible for HK regulation. 
CHAPTER 4

General Discussion 
Inhabitants of the marine intertidal zone usually possess high degrees of metabolic plasticity which enables them to tolerate the constantly changing environmental conditions imposed by the tidal cycle. A few of the environmental stresses which intertidal zone animals must cope with include desiccation, changes in salinity, wide variations in oxygen availability, and drastic changes in temperature; all of which can change rapidly throughout a single tidal cycle (Bridges, 1994).

Intertidal marine molluscs, ranging from bivalves to gastropods have been thoroughly researched due to their ability to tolerate anoxia, including the model animal examined here, the common periwinkle snail $L$. littorea (Larade et al., 2001; Larade and Storey, 2002; English and Storey, 2003; MacDonald and Storey, 2006).

There are a variety of situations in which marine molluscs can encounter anoxic environments. Snails become air exposed which causes oxygen limitation when the waters retreat with every low tide; and if tissue oxygen becomes fully exhausted, they must meet all cellular demands by anaerobic metabolism (Truchot and Duhamel-Jouve, 1980). Furthermore, predation and high salt or toxin levels can induce self-enclosure of the operculum and impose anoxia on the snail (de Zwaan and Putzer, 1985). Also, marine molluscs living in northern regions can experience sub-zero air temperatures during aerial exposures at low tide during the winter. As a result, they have developed freeze tolerance but when body fluids freeze, oxygen circulation ceases and so freezing also causes anoxia (Loomis, 1995).

Metabolic rate depression is the most critical factor in the survival of long term anaerobiosis since it strongly reduces metabolism to levels that can be sustained over the long term by fermentative pathways of ATP generation (Storey and Storey, 1990; 
Churchill and Storey, 1996; Brooks and Storey; 1997; Larade and Storey, 2007). By arresting metabolism at an early stage in response to external stresses, animals can limit or prevent metabolic and cellular damage (Brooks and Storey, 1997). The metabolic rate of $L$. littorea during anoxia is reduced to less than $10 \%$ of its resting aerobic rate by coordinating the suppression of numerous ATP-expensive cellular processes, which greatly extends the time that fixed tissue reserves of fermentable fuels can sustain life (de Zwann et al., 1991; van den Thillart et al., 1992; Storey, 1993). Other important biochemical adaptations of anoxia-tolerant molluscs include the maintenance of high levels of fermentable fuels and the use of alternative pathways of fermentative metabolism to increase ATP yield, maintain homeostasis and minimize acid build-up normally associated with anaerobic glycolysis (Churchill and Storey, 1989; Storey and Storey, 1990; de Zwann et al., 1991; Storey, 1993; Larade and Storey, 2004; Storey and Storey, 2004b).

It is generally understood that entry into a hypometabolic state does not involve major changes in the overall protein levels in cells because pathways such as protein synthesis or degradation require large energy supplies and that would be counterproductive in an energy-limited state such as anoxia (Storey and Storey, 2004b). Instead of modifying the overall enzyme levels in response to anoxia, facultative anaerobes such as the $L$. littorea use post-translational mechanisms as an energy-efficient means to alter the activity state of existing enzymes to facilitate the transitions to and from the hypometabolic state.

Covalent modification of an enzyme by protein kinases or phosphatases has immediate and substantial effects on enzyme function (Storey and Storey, 2004a). The 
addition of a phosphate functional group to an enzyme can readily induce conformational changes because of its negative charge, hydrophilicity, and relatively bulky shape (Hurley et al., 1990). Protein phosphorylation in animal cells typically targets serine/threonine or tyrosine residues because they respectively contain free hydroxyl or phenolic groups. Phosphorylation is catalyzed by protein kinases which transfer the terminal phosphate from ATP onto the target amino acid residue. Protein phosphorylation is a very stable covalent modification which requires specific Ser/Thr or Tyr protein phosphatases for the removal of the phosphate functional group in vivo.

Control of enzyme activity is central to anoxia survival and protein phosphorylation regulates almost all aspects of cell life (Eberlee and Storey, 1988). A single extracellular signal, transmitted through membrane receptors, can change the levels of intracellular second messengers, which activate specific protein kinases that phosphorylate a variety of target enzymes and thus alter the activities of a variety of cellular processes in a coordinated function (Figure 1.3; Storey, 1993). Some metabolic enzymes, for example glycogen phosphorylase, are controlled in an on-off manner by reversible phosphorylation, as are many signal transduction enzymes. However, more often the effects of phosphorylation on metabolic enzymes are to modulate the properties of the enzyme including activity, substrate affinity, sensitivity to inhibitors or activators, and binding interactions with other cellular proteins. Simplicity, flexibility, and reversibility are three of the fundamental factors supporting the use of phosphorylation to regulate many biological processes, including metabolic rate control.

Covalent modification of proteins by reversible phosphorylation is known to be involved in many cellular events including: (i) the binding of extracellular factors to 
membrane receptors (which depend on receptor-mediated kinase/phosphatase activation to transmit the signal inside the cell); (ii) transduction of signals from the plasma membrane to the nucleus (via major signal transduction pathways such as the mitogenactivated protein kinase (MAPK) superfamily); (iii) gene expression (transcription factor activity is often modified by phosphorylation state); (iv) ribosomal assembly and protein synthesis (ribosomal proteins, initiation and elongation factors can be regulated by phosphorylation state); and (v) post-translational modification of proteins, resulting in changes in protein activity, regulatory properties, and binding associations (Cohen, 1989; Bertorello and Katz, 1993; Hardie and Carling, 1997; Hajduch et al., 2001; Hue et al., 2002; Cowan and Storey, 2003; Alonso et al., 2004; Bozulic et al., 2004; Storey and Storey, 2004b; Khundmiri et al., 2005).

Earlier studies on the anoxia-tolerant gastropod molluscs, $L$. littorea and $B$. canaliculatum, established that the ATP-producing pathways of carbohydrate catabolism are strongly suppressed during anoxia, via regulatory controls on rate-limiting enzymes including GP, PFK-1, PFK-2 and PK (Bosca and Storey, 1991; Brooks and Storey, 1990, 1991; Storey, 1993). The primary mechanism implicated in the reversible control of these enzymes was protein phosphorylation (Storey, 1993). Given that reversible phosphorylation is one of the most ubiquitous modes of metabolic regulation and that it has already been established as a regulatory mechanism in decreasing the rate of ATPproducing carbohydrate catabolism in L. littorea; the presented research aimed to further explore the role of regulatory phosphorylation in other areas of metabolism that could facilitate survival during anoxia (Russell and Storey, 1995). In this thesis it has been demonstrated that reversible protein phosphorylation plays a crucial role in the regulation 
of metabolism during anoxia. Furthermore, the research investigated specific protein kinases and phosphatases to identify those that were relevant to the control of anoxia in $L$. littorea.

\section{G6PDH regulation during anoxia}

G6PDH, the first and rate-limiting enzyme of the pentose phosphate pathway, is indispensable to the maintenance of the cytosolic pool of NADPH (Ramnanan and Storey, 2006a). The PPP has several important functions including the generation of reducing equivalents in the form of NADPH and the production of pentose sugars for synthesis of nucleic acids (Ozer et al., 2002). NADPH is required for a wide range of reductive biosyntheses (i.e. fatty acids, steroids) and antioxidant reactions (Aksoy et al., 2001). NADPH also fuels detoxification and biotransformation reactions catalyzed by cytochrome $\mathrm{P} 450$ and replenishes pools of reduced glutathione and thioredoxin, two of the key reducing agents in cells (Figure 1.4b; DiGiulio et al., 1989; Das and White, 2002). Reduced glutathione has the ability to scavenge singlet oxygen molecules and also acts as a substrate for GST-catalyzed antioxidant reactions (Abeles et al., 1992; Garrett and Grisham, 2005). Although biosynthesis is not a priority for anoxic molluses, protection against oxidative damage remains key for organisms that must remain viable over prolonged periods in a hypometabolic state (Hermes-Lima et al., 1998; Storey and Storey, 2004b).

G6PDH was activated in the hepatopancreas from anoxia-tolerant $L$. littorea, as evidenced by the decreased $K_{m}$ G6P under anoxia. This effect could possibly facilitate the enhancement of antioxidant defences under anoxic conditions, since arousal from 
anoxia is associated with oxygen free radical generation and a need to quickly mobilize antioxidant defenses (Lushchak et al., 2001; Storey and Storey; 2004b). In vitro incubations promoting the activity of several protein kinases (PKA, PKC, PKG, AMPK) were shown to reduce G6PDH activity in extracts of anoxic snails to the levels seen in control extracts; conversely, stimulation of specific protein phosphatases $(\mathrm{PP} 1+\mathrm{PP} 2 \mathrm{~A}$, PP2C) raised the activities in tissue extracts from control animals back to the levels seen in anoxic snails. G6PDH regulation by reversible protein phosphorylation has also been demonstrated in the estivating land snail, O. lactea (Ramnanan and Storey, 2006a). In that case, phosphorylation of control G6PDH by PKA and PKG resulted in a more active enzyme, characteristic of the estivated form (Ramnanan and Storey, 2006a). Although phosphorylation of an enzyme can be stimulatory, there are numerous examples of phosphorylation of key metabolic enzymes such as glycogen phosphorylase, pyruvate kinase and phosphofructokinase, resulting in an inhibitory effect on enzyme activity from a wide variety of animals ranging from invertebrates to vertebrates (Plaxton and Storey, 1984b; Storey, 1987). Therefore from the data presented in Chapter 2, it is clear that phosphorylation suppressed hepatopancreatic G6PDH activity under aerobic, control conditions and dephosphorylation enhanced enzyme activity during anoxia.

\section{HK regulation during anoxia}

Hexokinase is the first enzyme in glucose metabolism and its regulation has direct effects on both the storage and consumption of glucose, as well as on pathways which utilize its product, glucose-6-phosphate, namely glycolysis, the pentose phosphate pathway and glycogen synthesis (Figure 1.4a; Abnous and Storey, 2008). HK was 
investigated in two different tissues of the marine mollusc: the hepatopancreas and the foot muscle. The hepatopancreas makes up the majority of the visceral mass of the snail and is a key site for important metabolic functions such as protein synthesis, gluconeogenesis, glycogenolysis and other specific roles in digestion and excretion. The foot muscle controls the locomotion of the marine mollusc (Curtis and Barnes, 1989).

In L. littorea, it appears that $\mathrm{HK}$ activity is regulated in a tissue-specific manner. During anoxia, HK is respectively enhanced and suppressed, in the hepatopancreas and foot muscle; and the mechanism of this regulation is reversible protein phosphorylation.

In the hepatopancreas, HK was activated under anoxic conditions as evidenced by the decreased $\mathrm{K}_{\mathrm{m}}$ glucose. Under normoxic conditions, fatty acid oxidation is the primary fuel source of liver and the snail liver-like organ (hepatopancreas), but fatty acids cannot be catabolised under anoxia (Seifter and Englard, 1994; Stryrer, 1995; Stuart and Ballantyne, 1997). Hence, animals must completely rely on anaerobic fermentative pathways for energy, primarily fuelled by the fermentation of carbohydrate (glucose, glycogen) via anaerobic glycolysis (Ramnanan and Storey, 2006a; Storey and Storey, 2004b). Although glycogen is quantitatively the greatest reserve of carbohydrate, HK is important as the gateway for feeding all free glucose into glycolysis and also catalyzes the phosphorylation of all other hexoses, allowing cells to scavenge all available sugars to meet energetic demands for fuel (Seifter and Englard, 1994). Additionally, as presented in Chapter 2, G6PDH and the PPP are enhanced in the hepatopancreas under anoxia and it is postulated that this increase is necessary in order to produce NADPH reducing equivalents which are used in antioxidant defence (Ramnanan and Storey, 2006a). Therefore, it could be reasoned that a coordinated enhancement of hepatopancreas HK in 
anoxia is important for the provision of substrate to both the glycolytic and the pentose phosphate pathways. In vitro incubations of hepatopancreas extracts which stimulated the activity of several protein kinases (PKG, PKC, AMPK) were shown to decrease HK activity (increase $\mathrm{K}_{\mathrm{m}}$ glucose) in extracts of anoxic snails to the levels seen in control extracts. By contrast, activation of specific protein phosphatases (PP1+PP2A, PP2B, Total Ser/Thr) enhanced the activity (decrease $\mathrm{K}_{\mathrm{m}}$ glucose) measured in tissue extracts from control animals back to the levels seen in anoxic snails. PKG has been implicated in the regulation of a variety of enzymes such as G6PDH and $\mathrm{Na}^{+} / \mathrm{K}^{+}$-ATPase in an assortment of animals from estivating snails to hibernating squirrels, and therefore it can be postulated that PKG may be the actual kinase, in nature, that regulates hepatopancreas HK in L. littorea (MacDonald and Storey, 1999; Ramnanan and Storey, 2006a).

Conversely in the foot muscle, HK was suppressed in anoxia as evidenced by its increased $\mathrm{K}_{\mathrm{m}}$ ATP and decreased maximal velocity. These findings are consistent with a general decrease in metabolic rate experienced by marine molluscs under anoxia (Storey and Storey, 2004b). Additionally, the decrease in activity could be due to the fact that during anoxia, the snail attempts to conserve as much energy as possible and therefore would not be using its foot muscle for unnecessary locomotion as it may do under normoxia. In vitro incubations of foot muscle extracts under conditions promoting the activity of several protein kinases (PKA, PKC, PKG, CaMK) were shown to reduce HK activity (increase $\mathrm{K}_{\mathrm{m}}$ ATP) in control snails to levels observed in anoxic snails; conversely, stimulation of all protein phosphatases tested (PP1, PP1+PP2A, PP2B, PP2C, Total Ser/Thr) enhanced the activities (decrease $K_{m}$ ATP) measured in tissue extracts from anoxic snails back to the levels seen in control snails. This is one of the first 
examples of $\mathrm{HK}$ regulation by reversible protein phosphorylation in an animal experiencing hypometabolism since it has only been recently demonstrated to be regulated in the skeletal muscle of the hibernating ground squirrel, S. richardsonii (Abnous and Storey, 2008).

\section{Role of Kinases and Phosphatases in L. littorea}

As previously mentioned, the phosphorylation of a protein can result in either the enhancement or suppression of enzyme activity (Plaxton and Storey, 1984b; Storey, 1987). In the anoxia-tolerant marine mollusc, L. littorea, it appears that the role of kinases and phosphatases played a similar role in regulating these two critical metabolic enzymes (G6PDH and HK) by reversible protein phosphorylation. In both cases of enzyme enhancement under anoxic conditions (G6PDH and HK from the hepatopancreas), phosphatases were responsible for removing phosphate functional groups from the low-activity, high-phospho control enzyme upon entry into hypometabolism; and producing a high-activity, low-phospho anoxic enzyme (Chapter 2, 3). Upon recovery to normoxia, both of these enhanced enzymes would again be phosphorylated by specific kinases in order to produce the low-activity, high-phospho control enzyme.

For the case of enzyme suppression (HK from the foot muscle), the opposite occurred. Kinases were responsible for phosphorylating the high-activity, low-phospho control enzyme upon entry into anoxia to produce a low-activity, high-phospho anoxic enzyme (Chapter 3). Likewise, upon return to the aerobic state, specific phosphatases were shown to dephosphorylate the suppressed enzyme in order to produce the high- 
activity, low-phospho control enzyme. Also in L. littorea, other key, pace-making enzymes of glycolysis (PFK-1 and PK) have previously been shown to undergo anoxiainduced phosphorylation which strongly suppressed their activities (Greenway and Storey, 2001). Therefore, it appears that for G6PDH and HK in L. littorea, phosphorylation at certain consensus sequences is involved in suppressing enzyme activity whereas dephosphorylation is used to enhance enzyme activity.

\section{Conclusion}

In conclusion, the work presented in this thesis builds on previous studies of the metabolic enzymes of carbohydrate metabolism to further demonstrate the importance of reversible phosphorylation in metabolic control during anoxia in the marine mollusc, $L$. littorea. New contexts of $L$. littorea metabolism, such as the pentose phosphate pathway, were shown to be regulated by anoxia-induced reversible phosphorylation of G6PDH. Also, hexokinase was identified as another important enzyme of glycolysis, which was regulated by reversible protein phosphorylation during anoxia. This thesis also implicated several specific protein kinases and protein phosphatases as being responsible for the regulation of G6PDH and HK. This greatly expands our understanding of the metabolic regulation of anaerobic metabolism. Furthermore, various mechanisms illustrated here for marine molluscs may prove to be general principles of metabolic rate depression that are applicable across the animal kingdom.

\section{Future Directions}

The research presented in this thesis establishes important points; however it also 
suggests some new directions for future work. The data presented in Chapter 2 shows that G6PDH is enhanced during anoxia in $L$. littorea, possibly to produce NADPH reducing equivalents for use in antioxidant defense. Therefore, it may be valuable to directly investigate the responses to anoxia by some antioxidant defense enzymes, such as superoxide dismutase or glutathione peroxidase. Both of these enzymes have been previously reported as being enhanced during hypometabolism of the estivating land snail O. lactea (Hermes-Lima et al., 1998). It is therefore plausible that these enzymes would also be enhanced in the marine mollusc during anoxia.

Furthermore, this thesis implicated several protein kinases and protein phosphatases in the regulation of G6PDH and HK in the anoxia-tolerant marine mollusc. Therefore, it would be of interest to investigate the kinetic properties of these specific protein kinases and phosphatases to determine if they are differentially regulated in normoxic and anoxic snails. Since, for example, the suppression of foot muscle HK during anoxia involves phosphorylation by kinases such as PKA, it would be important to determine if PKA activity, itself, was enhanced during anoxia. To do so, one may employ a variety of laboratory techniques such as radioactive kinase assays or fluorometric kinase assays. Similar experiments could be performed on specific protein phosphatases using the malachite green assay which measures the amount of inorganic phosphate produced by the protein phosphatase of interest. Information gained by these experiments will help present a clearer picture on the role of kinases and phosphatases on enzyme regulation during anoxia in the marine mollusc.

Another area of interest to investigate in the future deals with the ability of $L$. littorea to cope with freezing. As mentioned earlier, at high latitudes this intertidal 
marine mollusc is also freeze-tolerant since it is exposed to subzero temperatures at low tide during the winter season (Churchill and Storey, 1996). It would be of interest to characterize these enzymes in frozen snails to establish a possible correlation between hypometabolism, anoxia and freezing. Also, assessment of enzyme function and kinetic parameters at low temperatures would be important to determine if there is temperaturedependent regulation of these enzymes in the frozen state. 


\section{REFERENCES}


Abeles, R., Frey, P., and Jencks, W. 1992. Biochemistry. Jones and Bartlett Publishers. Boston, U.S.A, pp.320-321, 474, 659.

Abnous, K. and Storey, K. 2007. Regulation of skeletal muscle creatine kinase from a hibernating mammal. Archives of Biochemistry and Biophysics. 467: 10-19.

Abnous, K. and Storey, K. 2008. Skeletal muscle hexokinase: regulation in mammalian hibernation. submitted.

Aksoy, Y., Ogus, I., and Ozer, N. 2001. Purification and some properties of glucose-6phosphate dehydrogenase. Protein Expression and Purification. 21: 286-292.

Alms, G., Sanz, P., Carlson, M., and Haystead, T. 1999. Reg1p targets protein phosphatase 1 to dephosphorylate hexokinase II in Saccharomyces cerevisiae: characterizing the effects of a phosphatase subunit on the yeast proteome. The EMBO Journal. 8: 4157-4168.

Alonso, A., Sasin, J., Bottini, N., Friedberg, I., Friedberg, I., Osterman, A., Godzik, A., Hunter, T., Dixon, J., and Mustelin, T. 2004. Protein tyrosine phosphatases in the human genome. Cell. 117: 699-711.

Beavo, J. 1988. Multiple isozymes of cyclic nucleotide phosphodiesterase. In: Advances in Second Messenger and Phosphoprotein Research. (eds. Greengard, P. and Robinson, G). Raven Press, New York, pp. 1-35.

Benovic, J., Bouvier, M., Caron, M., and Lefkowitz, R. 1988. Regulation of adenylyl cyclase coupled beta-adrenergic receptors. Annual Review of Cell Biology. 4: 405428.

Berg, J., Tymoczko, L., and Stryer, L. 2002. Biochemistry ( $5^{\text {th }}$ Edition). W.H.Freeman and Company: New York.

Berger, V. and Kharazova, A. 1997. Mechanism of salinity adaptations in marine molluscs. Hydrobiologia. 355: 115-126.

Bertorello, A. and Katz, A. 1993. Short-term regulation of renal Na-K-ATPase activity: physiological relevance and cellular mechanisms. The American Journal of Physiology. 265: F743-F755.

Bosca, L. and Storey, K. 1991. Inactivation of 6-phosphofructo-2-kinase during anaerobiosis in the marine whelk Busycon canaliculatum. The American Journal of Physiology. 260: R1168-R1175

Bozulic, L., Dean, W. and Delamere, N. 2004. The influence of protein tyrosine phosphatase-1B on Na,K-ATPase activity in lens. The Journal of Cell Physiology. 200: 370-376. 
Bridges, C. 1994. Ecophysiological Adaptations in Intertidal Rockpool Fishes. In: Water/Air Transition in Biology (eds. Mittal, A., Eddy, F. and Datta-Munshi, J.). Oxford IBH Publishing Co., New Delhi, India, pp. 59-92.

Brooks, S. and Storey, K. 1990. cGMP-stimulated protein kinase phosphorylates pyruvate kinase in an anoxia-tolerant marine mollusc. Journal of Comparative Physiology - B. 160: 309-316.

Brooks, S., de Zwaan, A., van den Thillart, G., Cattani, O., Cortesi, P., and Storey, K. 1991. Differential survival of Venus gallina and Scapharca inaequivalvis during anoxic stress: covalent modification of phosphofructokinase and glycogen phosphorylase during anoxia. Journal of Comparative Physiology B. 161: 207212.

Brooks, S. and Storey, K. 1991. The role of protein kinases in anoxia tolerance in facultative anaerobes: purification and characterization of a protein kinase that phosphorylates pyruvate kinase. Biochimica et Biophysica Acta. 1073: 253-259.

Brooks, S. and Storey, K. 1997. Glycolytic controls in estivation and anoxia: a comparison of metabolic arrest in land and marine molluscs. Comparative Biochemistry and Physiology A. 118: 1103-1114.

Bullock, B. and Habener, J. Phosphorylation of the cAMP response element binding protein CREB by cAMP-dependent protein kinase $\mathrm{A}$ and glycogen synthase kinase-3 alters DNA-binding affinity, conformation, and increases net charge. Biochemistry. 37(11): 3795-3809.

Busa, W. and Nuccitelli, R. 1984. Metabolic regulation via intracellular pH. American Journal of Physiology. 246: R409-R438.

Churchill, T. and Storey, K. 1989. Intermediary energy metabolism during dormancy and anoxia in the land snail Otala lactea. Physiological Zoology. 62:1015-1030.

Churchill, T. and Storey, K. 1996. Metabolic responses to freezing and anoxia by the periwinkle Littorina littorea. Journal of Thermal Biology. 21: 57-63.

Cohen, P. 1989. The structure and regulation of protein phosphatases. Annual Review of Biochemistry. 58: 453-508.

Costa Rosa, L., Curi, R., Murphy, C., and Newsholme, P. 1995. Effect of adrenaline and phorbol myristate acetate or bacterial lipopolysaccharide on stimulation of pathways of macrophage glucose, glutamine and $\mathrm{O}_{2}$ metabolism. Evidence for cyclic AMP-dependent protein kinase mediated inhibition of glucose-6-phosphate dehydrogenase and activation of NADP+-dependent 'malic' enzyme. The Biochemical Journal. 310: 709-714. 
Cowan, K. and Storey, K. 2003. Mitogen-activated protein kinases: new signaling pathways functioning in cellular responses to environmental stress. The Journal of Experimental Biology. 206: 1107-1115.

Curtis, H. and Barnes, N. 1989. Part 2. Biology of Organisms. In: Classification of Organisms (eds. H. Curtis and N. Barnes). Worth Publisher, Inc., New York, pp. 1188-1189.

de Zwaan, A. 1977. Anaerobic energy metabolism in bivalve molluscs. Oceanography and Marine Biology: An Annual Review. 15: 103-187.

de Zwaan, A. and Putzer, V. 1985. Metabolic adaptations of intertidal invertebrates to environmental hypoxia (a comparison of environmental anoxia to exercise anoxia). Symposia of the society of experimental biology. 39: 33-62.

de Zwaan, A., Cortesi, P., van den Thillart, G., Roos, J., and Storey, K. 1991. Differential sensitivities to hypoxia by two anoxia-tolerant marine molluscs: a biochemical analysis. Marine Biology. 111: 343-351.

Das, K. and White, C. 2002. Redox systems of the cell: possible links and implications. Proceedings of the National Academy of Sciences USA. 99: 9617-9618.

DiGiulio, R., Washburn, P., Wenning, R., Winston, G., and Jewell, C. 1989. Biochemical responses in aquatic animals: a review of determinants of oxidative stress. Environmental Toxicology and Chemistry. 8: 1103-1123.

Eberlee, J. and Storey, K. 1988. Tissue-specific biochemical responses during anoxia and recovery in the channelled whelk. Journal of Experimental Marine Biology and Ecology. 121: 165-176.

Ellington, W. 1983a. Phosphorus nuclear magnetic resonance studies of energy metabolism in molluscan tissues. Journal of Comparative Physiology. 137: 165171.

Ellington, W. 1983b. The extent of intracellular acidification during anoxia in the catch muscles of two bivalve molluscs. Journal of Experimental Zoology. 227: 313-317.

English, T. and Storey, K. 2003. Freezing and anoxia stresses induce expression of metallothionein in the foot muscle and hepatopancreas of the marine gastropod Littorina littorea. Journal of Experimental Biology. 206(14): 2517-2524.

Floyd, R. 1990. Role of oxygen free radicals in carcinogenesis and brain ischemia. The Federation of American Societies for Experimental Biology Journal. 4: 25872597. 
Fretter, V. and Graham, A. 1976. A Functional Anatomy of Invertebrates, Academic Press, London.

Gabbott, P. 1983. Developmental and seasonal metabolic activities in marine molluscs. In The Mollusca. Vol. 2. (eds. P.W. Hochachka). Academic Press, New York. pp. 165-217.

Garrett, R. and Grisham, C. 2005. Biochemistry: $3^{\text {rd }}$ Edition. Thomson Brooks/Cole. U.S.A.

González, C., Ureta, T., Sanchez, R., and Niemeyer, H. 1964. Multiple molecular forms of ATP:hexose 6-phosphotransferase from rat liver. Biochemical and Biophysical Research Communications. 16: 347-352.

Greenway, S. and Storey, K. 2001. Effects of seasonal change and prolonged anoxia on metabolic enzymes of Littorina littorea. Canadian Journal of Zoology. 79: 907915.

Hajduch, E., Litherland, G., and Hundal, H. 2001. Protein kinase B (PKB/Akt)--a key regulator of glucose transport? FEBS Letters. 492: 199-203.

Halliwell, B. and Gutteridge, J. 1989. Free Radicals in Biology and Medicine, 2nd ed. Clarendon Press, London, pp. 139-187.

Hand, S. and Hardewig, I. 1996. Downregulation of cellular metabolism during environmental stress: mechanisms and implications. Annual Review of Physiology. 58: 539-563.

Hardie, D. and Carling, D. 1997. The AMP-activated protein kinase--fuel gauge of the mammalian cell? European Journal of Biochemistry. 246: 259-273.

Hermes-Lima, M., Storey, J., and Storey K. 1998. Antioxidant defenses and metabolic depression. The hypothesis of preparation for oxidative stress in land snails. Comparative Biochemistry and Physiology B, 120: 437-448.

Hochachka, P. and Somero, G. 1984. Biochemical Adaptation. Princeton University Press, Princeton, NJ.

Holmes, B., Kurth-Kraczek, E., and Winder, W. 1999. Chronic activation of 5'AMPactivated protein kinase increases GLUT-4, hexokinase, and glycogen in muscle. Journal of Applied Physiology. 87: 1990-1995.

Holwerda. D., Veenhof, P., van Heugten, H., and Zandee, D. 1983. Modification of mussel pyruvate kinase during anaerobiosis and after temperature acclimation. Molecular Physiology. 3: 225-234. 
Holwerda, D., Veldhuizen-Tsoerkan, M., Veenhof, P., and Evers, E. 1989. In vivo and in vitro studies on the pathway of modification of mussel pyruvate kinase. Comparative Biochemistry and Physiology B. 92: 375-382.

Hue, L., Beauloye, C., Bertrand, L., Horman, S., Krause, U., Marsin, A., Meisse, D., Vertommen, D., and Rider, M. 2002. New targets of AMP-activated protein kinase. Biochemical Society Transactions. 31: 213-215.

Hurley, J., Dean, A., Sohl, J., Koshland, D., and Stroud, R. 1990. Regulation of an enzyme by phosphorylation at the active site. Science. 249(4972): 1012-1016.

Katzen, H. and Schimke, R. 1965. Multiple forms of hexokinase in the rat: tissue distribution, age dependency, and properties. Proceedings of the National Academy of Sciences USA. 54: 1218-1225.

Kerley, M. and Leaback, D. 1957. The characteristics of hexokinase from locust muscle. Biochemistry Journal. 67: 245-254.

Khundmiri, S., Dean, W., McLeish, K., and Lederer, E. 2005. Parathyroid hormonemediated regulation of $\mathrm{Na}+\mathrm{K}+-\mathrm{ATPase}$ requires ERK-dependent translocation of protein kinase $\mathrm{C} \alpha$. The Journal of Biological Chemistry. 280: 8705-8713.

Kimura, K., Spate, L., Green, M., and Roberts, R. 2004. Effects of oxidative stress and inhibitors of the pentose phosphate pathway on sexually dimorphic production of IFN-tau by bovine blastocysts. Molecular Reproduction and Development. 68(1): 88-95.

Kohler, G. and Lindl, T. 1980. Effects of 5-hydroxytryptamine, dopamine and acetylcholine on accumulation of cAMP and cGMP in the anterior byssus retractor muscle of Mytilus edulis L. (Mollusca). Pflügers Archives: European Journal of Physiology. 383: 257-262.

Kuznetsova, L. and Plesneva, S. 2001. Effects of biogenic amines and polypeptide hormones on protein kinase A and adenylyl cyclase activities in muscles of the mollusc Anodonta cygnea. Journal of Evolutionary Biochemistry and Physiology. 37: 520-527.

Larade, K., Nimigan, A., Storey, K. 2001. Transcription pattern of ribosomal protein L26 during anoxia exposure in Littorina littorea. The Journal of Experimental Biology. 290: 759-768.

Larade, K. and Storey, K. 2002. Characterization of a novel gene up-regulated during anoxia exposure in the marine snail, Littorina littorea. 283: 145-154.

Larade, K. and Storey, K. 2002. A profile of the metabolic responses to anoxia in marine 
invertebrates. In: Cell and Molecular Responses to Stress Vol. 3: Sensing, signaling and cell adaptation. (eds. Storey, K. and Storey, J.). Elsevier Press, Amsterdam, pp. 27-46.

Larade, K. and Storey, K. 2007. Arrest of transcription following anoxic exposure in a marine mollusc. Molecular and cellular biology. 303:243-249.

Larini, A., Bianchi, L., and Bocci, V. 2004. Effect of 4-hydroxynonenal on antioxidant capacity and apoptosis induction in Jurkat T cells. Free Radical Research. 38(5): 509-516.

Lazou, A. 1991. Regulation of phosphofructokinase in the foot muscle of Patella caerulea L. during exposure to air. Journal of Experimental Zoology. 259: 202208.

Lewandrowskia, U., Sickmanna, A., Cesarob, L., Brunatib, A., Toninellob, A., and Salvib, M. 2008. Identification of new tyrosine phosphorylated proteins in rat brain mitochondria. FEBS Letters. 582: 1104-1110.

Livingstone, D. 1981. Induction of enzymes as a mechanism for the seasonal control of metabolism in marine invertebrates: glucose-6-phosphate dehydrogenases from the mantle and digestive gland of the common mussel Mytilus edulis L. Comparative Biochemistry and Physiology B. 69: 147-156.

Loomis, S. 1995. Freezing tolerance of marine invertebrates. Oceanography and Marine Biology: an Annual Review. 33: 337-350.

Lushchak, V., Lushchak, L., Mota, A., and Hermes-Lima, M. Oxidative stress and antioxidant defenses in goldfish Carassius auratus during anoxia and reoxygenation. The American Journal of Physiology - Regulatory, Integrative and Comparative Physiology. 280: R100-R107.

MacDonald, J. and Storey, K. 1999. Regulation of ground squirrel Na+K+-ATPase activity by reversible phosphorylation during hibernation. Biochemical and Biophysical Research Communications. 254: 424-429.

MacDonald, J. and Storey, K. 2006. Identification of a 115kDa MAP-kinase activated by freezing and anoxic stresses in the marine periwinkle, Littorina littorea. Archives of Biochemistry and Biophysics. 450: 208-214.

Madou, M. 2002. Fundamentals of Microfabrication: The Science of Miniaturization. $2^{\text {nd }}$ Edition. CRC Press, Boca Raton, pp 567-568.

Magnani, M., Serafini, G., Stocchi, V., Bossu, M., and Dacha, M. 1982. Solubilization, purification, and properties of rabbit brain hexokinase. Archives of Biochemistry and Biophysics. 216: 449-454. 
Michaelidis, B. and Storey, K. 1990. Phosphofructokinase from the anterior byssus retractor muscle of Mytilus edulis: modification of the enzyme in anoxia and by endogenous protein kinases. International Journal of Biochemistry. 22: 759-765.

Michaelidis, B. and Storey, K. 1991. Evidence for phosphorylation/ dephosphorylation control of phosphofructokinase from organs of the anoxia-tolerant sea mussel Mytilus edulis. Journal of Experimental Zoology. 257: 1-9.

Muise, A. and Storey, K. 2001. Regulation of hexokinase in a freeze avoiding insect: role in the winter production of glycerol. Archives of Insect Biochemistry and Physiology. 47: 29-34.

Ozer, N., Bilgi, C., and Ogus H. 2002. Dog liver glucose-6-phosphate dehydrogenase: purification and kinetic properties. International Journal of Biochemistry and Cell Biology. 34: 253-262.

Pannunzio, T. and Storey, K. 1998. Antioxidant defenses and lipid peroxidation during anoxia stress and aerobic recovery in the marine gastropod Littorina littorea. Journal of Experimental Marine Biology and Ecology. 221(2): 277-292/

Pearson, R. and Kemp, B. 1991. Protein kinase phosphorylation site sequences and consensus specificity motifs: Tabulations. In: Methods in Enzymology. (eds. Hunter, T. and Sefton, B). Academic Press, New York, pp. 62-81.

Plaut, I. 1999. Effects of salinity on survival, osmoregulation, and oxygen consumption in the intertidal blenny, Parablennius sanguinolentus. Copeia. 1999: 775-779.

Plaxton, W. and Storey, K. 1982. Alanopine dehydrogenase: purification and characterization of the enzyme from Littorina littorea foot muscle. Journal of Comparative Physiology - B. 149: 57-65.

Plaxton, W. and Storey, K. 1984a. Purification and properties of aerobic and anoxic forms of pyruvate kinase from red muscle tissue of the channeled whelk, Busycotypus canaliculatum. European Journal of Biochemistry. 143: 267-272.

Plaxton, W. and Storey, K. 1984b. Phosphorylation in vivo of red muscle pyruvate kinase from the channeled whelk, Busycotypus canaliculatum, in response to anoxic stress. European Journal of Biochemistry. 143: 267-272.

Polakis, P. and Wilson, J. 1985. An intact hydrophobic N-terminal sequence is critical for binding of rat brain hexokinase to mitochondria. Archives of Biochemistry and Biophysics. 236: 328-337.

Pörtner, H., Grieshaber, M., and Heisler, N. 1984. Anaerobiosis and acid-base status in 
marine invertebrates: Effect of environmental hypoxia on extracellular and intercellular $\mathrm{pH}$ in Sipunculus nudus L. Journal of Comparative Physiology. 155: 13-20.

Purich, D., Fromm, H., and Rudolph, F. 1973. The hexokinases: kinetic, physical, and regulatory properties. Advances in Enzymology and related areas of Molecular Biology. 39: 249-326.

Ramnanan, C. and Storey, K. 2006a. Glucose-6-phosphate dehydrogenase regulation during hypometabolism. Biochemical and Biophysical Research Communications. 339: 7-16

Ramnanan, C. and Storey, K. 2006b. Suppression of Na+/K+-ATPase activity during estivation in the land snail Otala lactea. Journal of Experimental Biology. 209: 677-688.

Randez-Gil, F., Sanz, P., Entian, K., and Prieto, J. 1998. Carbon source-dependent phosphorylation of hexokinase PII and its role in the glucose-signaling response in yeast. Molecular and Cellular Biology. 18(5): 2940-2948.

Robey, R. and Hay, N. 2006. Mitochondrial hexokinases, novel mediators of the antiapoptotic effects of growth factors and Akt. Oncogene. 25(34): 4683-4696.

Ross, E. and Gillman, A. 1980. Biochemlcal properties of hormone-sensitive adenylate cyclase. Annual Review of Biochemistry. 49: 533-564.

Russell, E. and Storey, K. 1995. Anoxia and freezing exposures stimulate covalent modification of enzymes of carbohydrate metabolism in Littorina littorea. Journal of Comparative Physiology - B. 165:132-142.

Sailaja, Y., Baskar, R., and Saralakumari, D. 2003. The antioxidant status during maturation of reticulocytes to erythrocytes in type 2 diabetics. Free Radical Biology and Medicine. 35(2): 133-139.

Salway, J. 2004. Metabolism at a Glance, $3^{\text {rd }}$ Edition. Blackwell Publishing Inc., Malden, Massachusetts.

Schmidt, H. and Kamp, G. 1996. The Pasteur effect in facultative anaerobic metazoa. Experientia. 52: 440-448.

Schoffeniels, E. 1976. Adaptations with respect to salinity. Biochemical Society Symposium. 41:179-204.

Seifter, S. and Englard, S. 1994. Chapter 20. Energy Metabolism. In: The Liver: Biology and Pathology, Third Edition. (eds. Arias, I., Boyer, J., Fausto, N., Jakoby, W., Schachter, D., and Shafritz, D.) Raven Press, Ltd.. New York, pp. 323-350. 
Shick, J., de Zwaan, A., and de Ronr, A. 1983. Anoxic metabolic rate in the mussel Mytilus edulis L. estimated by simultaneous direct calorimetry and biochemical analysis. Physiological Zoology. 56: 56-63.

Shumway, S. 1977. Effect of salinity fluctuation on the osmotic pressure and $\mathrm{Na}^{+}$, $\mathrm{Ca}^{2+}$ and $\mathrm{Mg}^{2+}$ ion concentrations in the hemolymph of bivalve molluscs. Marine Biology. 41: 153-177.

Slekar, K., Kosman, D., and Culotta, V. 1996. The yeast copper/zinc superoxide dismutase and the pentose phosphate pathway play overlapping roles in oxidative stress protection. The Journal of Biological Chemistry. 271(46): 28831-28836

Sokolova, I., Bock, C., and Portner, H. 2000. Resistance to freshwater exposure in White Sea Littorina spp. II: Acid-base regulation. Journal of Comparative Physiology $B$. 170: $105-115$.

Somero, G. and Bowlus, R. 1983. Osmolytes and Metabolic End Products of Molluscs: The Design of Compatible Solute Systems. In: The Mollusca, Vol. 2. Environmental Biochemistry and Physiology. (eds. P. Hochachka). Academic Press, Inc., New York, pp. 77-98.

Stoppani, J., Hildebrandt, A., Sakamoto, K., Cameron-Smith, D., Goodyear, L. and Neufer, P. 2002. AMP-activated protein kinase activates transcription of the UCP3 and HKII genes in rat skeletal muscle. American Journal of Physiology. 283. E1239-E1248

Storey, K. 1980. Regulatory properties of hexokinase from flight muscle of Schistocerca americana gregaria. Role of the enzyme in control of glycolysis during the restto-flight transition. Insect Biochemistry. 10: 637-645.

Storey, K. 1987. Regulation of liver metabolism by enzyme phosphorylation during mammalian hibernation. Journal of Biological Chemistry. 262: 1670-1673.

Storey, K. 1988a. Mechanisms of glycolytic control during facultative anaerobiosis in a marine mollusc: tissue specific analysis of glycogen phosphorylase and fructose2,6-bisphosphate. Canadian Journal of Zoology. 66: 1767-1771.

Storey, K. 1988b. Suspended animation: the molecular basis of metabolic depression. Canadian Journal of Zoology. 66: 124-131.

Storey, K. 1993. Molecular mechanisms of metabolic arrest in mollusks. In: Surviving Hypoxia: Mechanisms of Control and Adaptation (eds. P. Hochachka, P. Lutz et al.). CRC Press, Boca Raton, pp. 253-269.

Storey, K. and Storey, J. 1990. Metabolic rate depression and biochemical adaptation in 
anaerobiosis, hibernation and estivation. Quarterly Review of Biology. 65: 145174.

Storey, K. and Storey, J. 2004a. Metabolic rate depression in animals: transcriptional and translational controls. Biological Reviews of the Cambridge Philosophical Society. 79: 207-233.

Storey, K. and Storey, J. 2004b. Chapter 15. Oxygen Limitation and Metabolic Rate Depression. In: Functional Methabolism: Regulation and Adaptation. (eds. Storey, K). Wiley-Liss. New York, pp. 415-443.

Storey, K. and Storey, J. 2007. Tribute to P. L. Lutz: putting life on 'pause' - molecular regulation of hypometabolism. Journal of Experimental Biology. 210: 1700-1714.

Stryer, L. 1995. Biochemistry: Fourth Edition. W.H. Freeman and Company. New York, pp. 612, 773.

Stuart, J. and Ballantyne, J. 1997. Importance of ketone bodies to the intermediary metabolism of the terrestrial snail, Archachatina ventricosa: evidence from enzyme activities. Comparative Biochemistry and Physiology B. 117: 197-201.

Tian, W., Braunstein, L., Apse, K., Pang, J., Rose, M., Tian, X., and Stanton, R. 1999. Importance of glucose-6-phosphate dehydrogenase activity in cell death. The American Journal of Physiology. 276(5): 1121-1131.

Traystman, R., Kirsch, J., and Koehler, R. 1991. Oxygen radical mechanisms of brain injury following ischemia and reperfusion. Journal of Applied Physiology. 71: 1185-1195.

Truchot, J. and Duhamel-Jouve, A. 1980. Oxygen and carbon dioxide in the marine intertidal environment: diurnal and tidal changes in rockpools. Respiration physiology. 39(3): 241-254.

Ursini, M., Parrella, A., Rosa, G., Salzano, S., and Martini, G. 1997. Enhanced expression of glucose-6-phosphate dehydrogenase in human cells sustaining oxidative stress. The Biochemical Journal. 323(3): 801-806

van den Thillart, G., van Lieshout, G., Storey, K., Cortesi, P., and de Zwaan, A. 1992. Influence of long-term hypoxia on the energy metabolism of the haemoglobincontaining bivalve Scapharca inaequivalvis: critical $\mathrm{O}_{2}$ levels for metabolic depression. Journal of Comparative Physiology B. 162: 297-304.

Vaughan, H., Thorton, S. and Newsholme, E. 1973. The effects of calcium ions on the activities of trehalase, hexokinase, phosphofructokinase, fructose diphosphatase and pyruvate kinase from various muscles. Biochemistry Journal. 132: 527-535. 
Vojtek, A. and Fraenkel. D. 1990. Phosphorylation of yeast hexokinases. European Journal of Biochemistry. 190: 371-375.

Walsh, D., Newsholme, P., Cawley, K., van Patten, S., and Angelos, K. 1991. Motifs of protein phosphorylation and mechanisms of reversible covalent regulation. Physiological Reviews. 71: 285-315.

Walsh, P., McDonald, D., and Booth, C. 1984. Acid-base balance in the sea mussel, Mytilus edulis. II. Effects of hypoxia and air exposure on intracellular acid-base status. Marine Biology Letters. 5: 359-369.

Whitwam, R. and Storey, K.B. 1991. Regulation of phosphofructokinase during estivation and anoxia in the land snail Otala lactea. Physiological Zoology. 64: 595-610.

Wilson, J. 1973. Studies on the molecular weight and lipoprotein nature of glucose-6phosphate solubilized rat brain hexokinase. Archives of Biochemistry and Biophysics. 154: 332-340.

Wilson, J. 1997. An introduction to the isoenzymes of mammalian hexokinase types I-III. Biochemical Society Transactions. 25: 103-108.

Wilson, J. 2003. Isozymes of mammalian hexokinase: structure, subcellular localization and metabolic function. Journal of Experimental Biology. 206: 2049-2057.

Xu, Y., Osborne, B., and Stanton, R. 2005. Diabetes causes inhibition of glucose-6phosphate dehydrogenase via activation of PKA, which contributes to oxidative stress in rat kidney cortex. American Journal of Physiology. Renal Physiology. 289(5): 1040-1047.

Yancey, P., Clark, M., Hand, S., Bowlus, R., and Somero, G. 1982. Living with water stress: evolution of osmolyte systems. Science. 217:1214-22.

Zetterqvist, O., Ragnarsson, U., and Engstrom, L. 1990. Substrate specificity of cyclic AMP-dependent protein kinase. In: Peptides and Protein Phosphorylation. (eds. Kemp, B). CRC Press, Boca Raton, FL, pp. 171-187.

Zhang, Z., Apse, K., Pang, J., and Stanton, R. 2000. High glucose inhibits glucose-6phosphate dehydrogenase via cAMP in aortic endothelial cells. The Journal of Biological Chemistry. 275(51): 40042-40047. 